University of Louisville

ThinkIR: The University of Louisville's Institutional Repository

Electronic Theses and Dissertations

1935

\title{
The anatomy, systematic position, natural history and economic importance of the spoonbill ganoid, Polyodon spathula.
}

Oscar H. Steinberg

University of Louisville

Follow this and additional works at: https://ir.library.louisville.edu/etd

Part of the Aquaculture and Fisheries Commons

\section{Recommended Citation}

Steinberg, Oscar H., "The anatomy, systematic position, natural history and economic importance of the spoonbill ganoid, Polyodon spathula." (1935). Electronic Theses and Dissertations. Paper 1963.

https://doi.org/10.18297/etd/1963

This Master's Thesis is brought to you for free and open access by ThinkIR: The University of Louisville's Institutional Repository. It has been accepted for inclusion in Electronic Theses and Dissertations by an authorized administrator of ThinkIR: The University of Louisville's Institutional Repository. This title appears here courtesy of the author, who has retained all other copyrights. For more information, please contact thinkir@louisville.edu. 


\section{UNIVHKSITY OP LOUISVILLE}

THE AyATOMY, SYSTEMATIC POSI TION, MATURAZ, I! HI BTORY AMD BCONOMIC IUPORTANCE OF THE SPOOHEILI GAKOID, POLYODON BPATHULA

A DISOZRTAZION SUBLITTED TO THE FACULTY OP THL GRADUATS SCEOOL OP THE UNIVERSITY OH LOUISVILIE IN FAFTIAI WUIILMEXT OF TLE REQUIKEMENTS BOR THE DEGREX OF NASTRR OS SCIUHCE

DEPARTMENT OF BIOLOGY

BY

OSCAR H. STRINBELG 
DEDICATIOO

XY EIOHSST APPRECLATION AID DERP-

sST CratrFud: ARE DOE DA. GARVEY

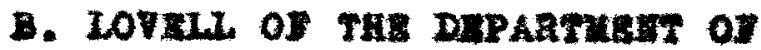

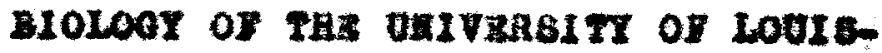

VILLE FOR HI8 DIRECTION ADD CON-

stavCTIV: CAITICISU OY THIS STUDY 


\section{DARACE}

This thesis aime to describe the anstomy of Polyodon spethule, a ganoid, showing ite position between the cartilaginous group of fishes, the masmobranohe and lower forme, and the nigher group, the Teleosts or bony fishes. Changes between slassobranohe and Ganolds are most warked in the derelopment of the large pylorio caecum, type of swin bladder. and the skeletal aystem. The okeletal oyotem is both cartilaginous and bony in etructure.

To a lesser degree, this thesio aims to gire an account of the economic importance, breeding habits and range of the spoonbill fich, as well as a general clasedfioation of the Aotinopterygil from which Polyodon hare adranced.

Acknowledgents are due to the University of Loulovilie, the Univeralty of Illinole, and the Univerelty of Tennessee for reference material obtalned; also to Dr. H. B. Lorell for his conetruetive critiolen of thie study, Dr. P. A. Daries for giving me access to use facilitieo necesary for study, Dr. J. F. Bradiey for corrections in Englioh of part of the thesle, and Mr. F. Nelton for the photography. 
TABLE OP CONTEMTS

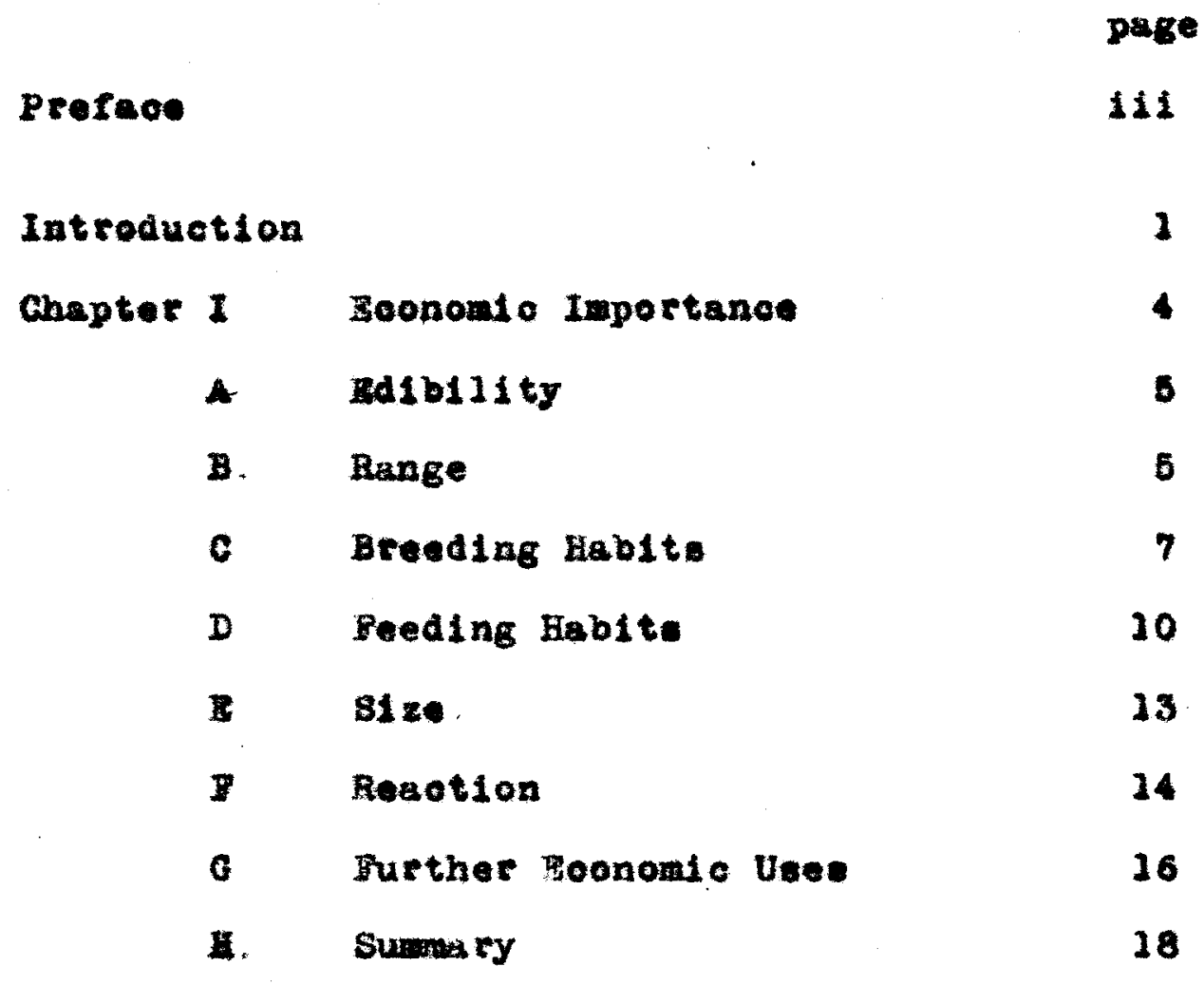

Chapter II Brief history and elaseiflation of the Osteichthyes with Speeial emphsai on the order Aotinopterygil (Genoides) and the place of Polyodontida among them 20

A Ostaichthyes in Goneraj 21

b Claseifiestion of Aotinopterygil 23

c Chart howing phylogeny of the 0steichthyes frow whioh the Aotinopterygil have adranced 31 
Pase

Gapter III

Axternal anstom and integument

of Polyodon epsthule Inoluding

an acoount of related form of

ranolde

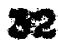

Introduetion

33

4 Brin and soajea in General 34

1. The evbetanee Gunein 37

D Extemal anatouy 30

1. Form 39

2. Munction 39

3. Cojer 40

4. Dine 40

6. Apertures 42

6. Operoulum 44

7. Integunent and lateral

Iine canal 44

- Heromeopio examInation of ehromatophores

8. Conparison of two ganotda. paddiefian and noodzefi on 48

c Bxternal anatery of the younget

epoonb111 ever recorded (1034) uleeIestppl elrer 50

D. $\operatorname{sex} \quad 52$ 
page

Chapter IV General Internal Antowy b4

A Porloardial coelom 55

B Abdominal Coelon 56

c Abdoninal Hecera $\quad 56$

D The Neenteries 68

Chepter $\checkmark$ Digentive and Restratory

Soteme 50

A Reglone of the Almentaty rract to

B Internal stmoture 65

1. Homtode infeation 65

c elands 66

1. Cecoun 66

2. Liter 67

3. Panoreas 67

4. Spleen 67

D Resplretor Struetures 69

Chapter II Ciroulatory systen 73

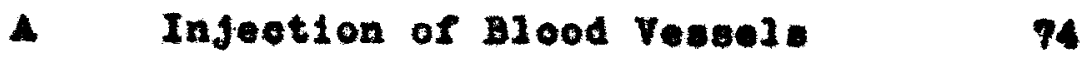

D The Heart 77

C The Veine 79

D Tentral Aorts and afferent Branohlal Arteries 81 
page

I Sfferent Branohial Arteries

and Doreal horte

64

Mapter VII skeletal syeten

88

Introduotion

89

A Axial skeleton 91

1. The craniun 92

2. Viceeral Skeleton

a. Landibular and hold

arehes

94

b. Bravohlad erahes

96

3. Table of Dermal and cartilaginous parto of the slrujl 98

1. Vertebral columa 90

b Appendioular skeleten 202

2. The palred flas 102

2. The unpalred rlas 104

3. The Julera 205

Oelcinal Contribution $\quad 106$

Bibllography 111

I12uetrations 117 


\section{IXTRODUCTIOI}

the fishes of the family Polyodon, in addition to their growing coonomio importance in Amorios, are of exeeptional intereat to blologiate on ecoount of theif prindtive oharis-21ke form and character, and thelf consequent importance in tracing the descent of the bony riahes. 2

It 10 rewarkable that the anatomy of suah an Important food fioh as the apoonbill. Polrodon epathula. has been so jittie atudied. It 1s, therefore, the main purpose of this study to present a detalled acoount of such anatomion structures as could be traced by grose disecetion.

Assiotance In Ident1fying these structures was obtalned fros the previous work of Forbed and Richerdeon (1900). wo briefly dencribed the okeletel oretem. Alex-

ender (1925) giree a brief resume of the visoera. Ooodrioh (2930), showe figures on the ckul and peotoral

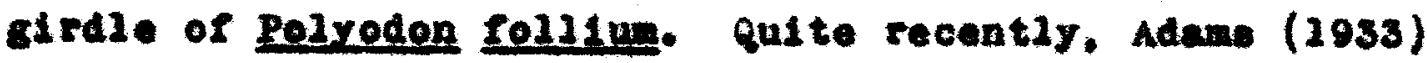
bnowe I1gures on the digeative syatem of Palyodon enchure.

3. A. Porbes and R. H. Rlohnrdeon, 1900, p. 15. 
The otudiel antioned above, howerec. are co

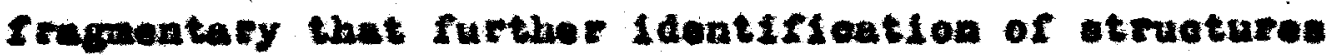
had to be worked ont by comparing the poonblil with

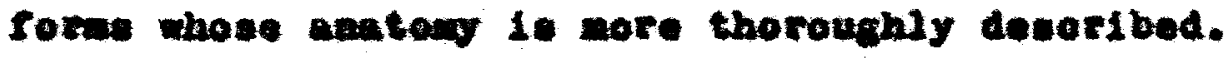
Prett (1905) and Hegner (1031) on the Tejeoste: Cam (1926). Hyman (1928). Dantere (2028, 303e) on the

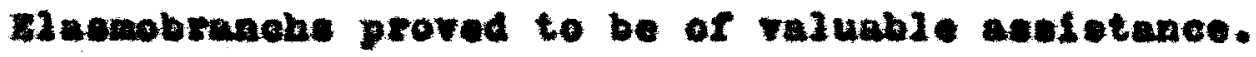
Kingelay (1925), Lanketer (1000), and water (1029)

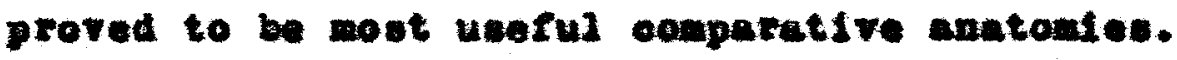
4 though wetund fieja etudies were not poublbie.

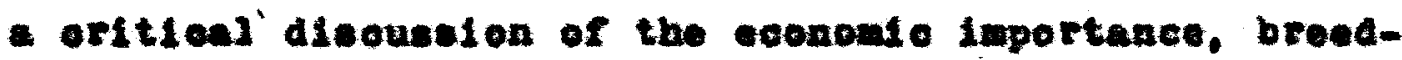

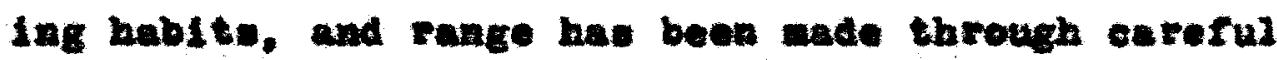
etuat of the weitings of numarous athore on the eubjeot. Percmest amone these suthore were Ruevalof (1911), Coker (1030). Bewniseh $(1033)$.

Phe larral stage of the spoonbl12 are almost unrnown, except for the divoovery of post-1arval stages by Thempen (2933).

The wuthor recomend thet the rurther inveetigetion of the breeding babite and Iarral derelopent be undertaken as noet frultrul slaja of receeroh. Btudiea on the enbryo might vell add Important erolutionery date. Coke (1930) pointe out our fundmantal zack of knowledge of the nost elemantal racte conoerafing the iffo ateteries of comon ribhes. Fo way nothine of the 
sponbill of hackleback sturgeon, who knowe when, where, and under whet conditions oocure the breoding of freahwater drum, blue sucker, river herring, of Ohio shed? The last mentloned fish, potentialiy an excellent food and fairiy abundant, as observation indicates bas not even been recorded hitherto fron the Hisbiselppl Rirer (1930). Who has observed the breeding (in nature) of any of the larger ostfighes of the Miesibeippl basing There 1. the "niggerlip" oatfieh during the ten monthe of the year. When it is rarely taken by comereial flobormone Who hes studied the modifleations of form and color correoponding to habits of ages of any of the catfishes or buffalo fighes? These are excellent opportuntiles for useful studies of fibhes that can be readily found in various treane of the Mealsaippi basin." 


\section{H}
ECOMONIC IUPOATAECE.

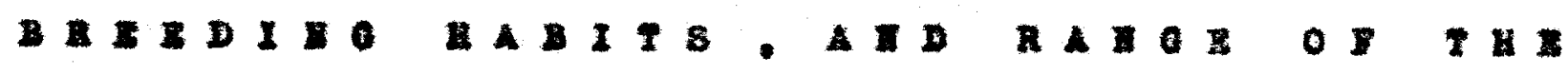

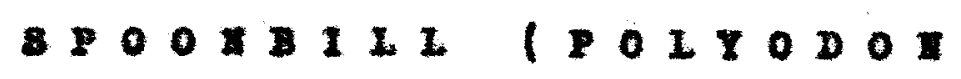

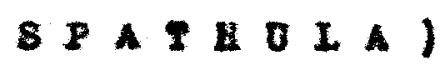


The ccononle inportanoe of the paddiefich of opoonbili is worthy of conalderation. A a food its Ieah is used both frowh and solked. In the fomales the reo is uned as osviar. At a epecies it is of pooullaz intereot, being arkedy different in form and etruoture from an othof fieh now 11wing except a singla opedes ocourring in certain rivere of China. Shark11ke in form, but not in beharlor or in quality of meat.

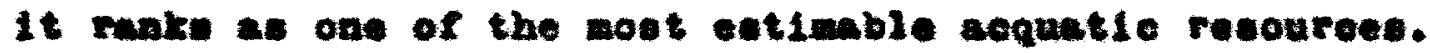
At tines it has secmed upon the rezge of extermination from overflehlas or other unforovable oonditions: yet apparentig it wowe rema rkable powers of endaranoe or roeuperation. Coker (1930) entinutes tho roe of an indvidual fich to igh from ten to sirteon poubds, and it nay have a velue of more than two dollare a pound. A large opoonbili usually means a raluable entoh. Yor the pant fow yeare, the Ileah of the fiah was not gonerally nold under its om name but appeared in the nerkote under the nawe of "sturgeon". Mow, howerer. 1t is known as epeosilil meat. In the vieinity of Lake Popla. In fact, the fishermen comoniy applied the name "oborelnose eturgeon" to the liring riah. 


\section{ediblity}

Jordon (2025) says that the meat of the spoonb111 is coarse and is not much asteemed. Recent otatist10 show ue that the meat of the epoonb11 is in denand (sette. 1025 ).

From personal experienoe, and in discuseion with several floh dealers, I found the following to be true In regard to spoonbill meat: The epoonb111 poeseseses - tough axial membrane (notocordal tiasue) extending from the head to the tall. If thil axial cond is remored before cooking. the neat of the spoonblil is excellent; otherwioe the gristiy struoture wake the fish unsatiefactory food. Hence, we see how differeat pointe of Tlew arise in regard to the edibility of spoonbill meat.

\section{Range}

The range of the spoonbild is in rivere and lake of the Miselsaippl basin and in some other tributaries of the Galf of kexico. The spoonbills that the author worked upon were taken from the Hiselesippi RIver in Maroh. 1934. While this fieh is rare in shajlow tributarles and has been supposed to prefer vaters exceeding 
ten reet in depth, yet it oocurs throughout the whole couree of the Hisalealppl River and is midely distributed in the basia. Acoerding to the unfted states

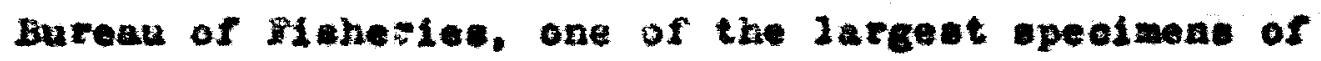
record was taken in Lake Chautauqua, How York. Caber (1930) say the more lmportant fiaheries for spoonbille hure been in laken of Louteliana, Miselosppl, and arkanase and in the chlo, IJlinole and risetosippl Rivere se far north as Lake Pepin between winaseota and tecensin. spoonbilis usupily are taken along vith extrishes, buffalo-fishes, and oarp in larce ceines. which may be bauled frow barges by the nee of reels or pulled sabere by the une of etatlonky winokes. They are aleo taken in neto at aight. In the visotesppi iiver in reeent years the ol see generally token range fron four to twelve pounds. Large exanples of twontyive to thirty-fire pounde in weight have been reported but are rare. Sioh of twojre to twenty-five pounde weight are sald to be more comon in the last rell yearo (before 1926) at polnte on Lake Keokuk. 
Arediag indie

In op1 te of the wot careful courabse by varione Inventigators vorking in and joeditiee, virtuajy nothIng hat been learaed concerning the breading hablts of the -poonbizl fioh. It is reported to brend in Loulolana (Alexander, 1915) and it has been found is acarly fipe conditios at Louiaridie, Kantueky. (Bverwan, 1902). There is aloo testimony that it epawn in central IIIinoie (alchardoon, 1923 ).

Coker (1930) states that flaberwen and dealere at and aear keokuk roport that they froquently take -ximples conteining eges and that the ree 1 e erreted for preperation as eaviar. Tagner (1900) exmining about 2.500 speolens Irom Lake Pepla, between Minnesota and Wlsoonia, fros Jube 21 to Beptember 2 , but none were found thet were nearly ripe or cecently epawned. stockacd (1007). Feom obonrvations made in Loulelane and Arkantes, concluded that the breeding eeacen in that part of the oountry was nbout the middle or latter part of April. Alien (1011) obtainod speolwene fout to olx lnches lone on July 1 natat Calro, IIInole, and Jargef ones o1x to twelve lnehes in length In late Augut or early september. It infered that 
the breoding seasen we in Warch.

All evidenoe Indloater that the apoonbill finh breade ather late in water or eariy in opring: and as young epeotwens have been obtalned et ceife, IIIInole.

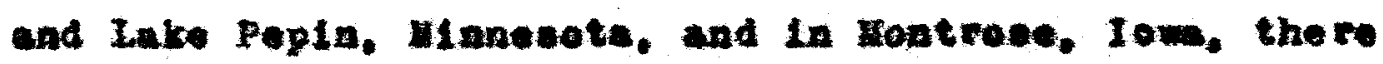

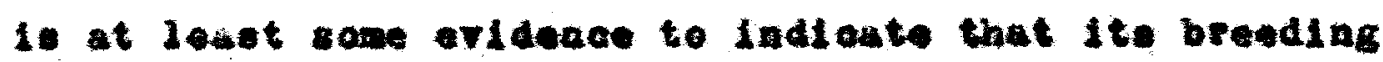
cotirities are confined bel ther to the northorn nor eouthern extrawes of ite tereitory.

There appoars to be a laok of ay defint te reoord of an extended algration of paddlefieh in an upetrean or downetrean direction. It has not beon know wethet the padelefieb or epoonblil of houlatana and Hinasecte were bred and reared in thair reopestive leculities or whether igrations cecurred between the extrem 2laits of the range of the specles. A "epring run" of spoonbill fich io sometions spoken of, but this expresition is used so generaly that no partioulas ittention gas be attacked to ite becring upon a agration of the cort in question.

stookard (1007) furaishes obeervation of a conopicuous 2atecal algration from rivere to lakes and reon lakes to rivere.

-During the opring. when the wite of the Mios-

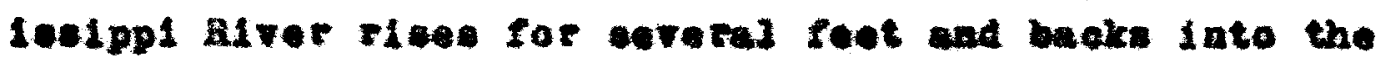
bayoup. thus ectablighing connections wth large lakes. polyoden begins inadiatejy to come into the jake from 
the edver and continues to cone in large mubere wo Jont we aurfielont connection is mantained. To do this it mat often make long jenrneys throuch rather challon wher, in wiob many obstruetions, suah as buches and troes, are froquently mot. Thus it rinally reaber the lakes in pather omnolated condition and with its body searred and beratohed. It Is equaliy true that the fish in the elrot lakes (the lakes wore direotly connected with the river) acrate out inte the river when the vater begins to beak is during the opring, we thet fichormen often

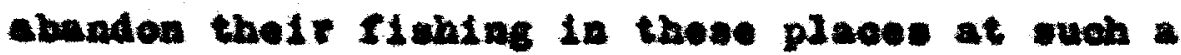
ceason, elwee wost of tho destrable Polyedon have ade their ecenpe."

Vagner (1908) sayn, "Bocaingly the opoondids is of a rather roving diapostion, erulatag up and down the lakes In Ierce cohools." If obeerved that it alght be taken sbunduntiy in the selne oes day. whereas the bext day there alght be nono.

Becaues Tery Iittie definite iaformation 1. known conceraing the breading habt te of the epoonbi12, nention of the breoding of the 20ngaosed gar, a elose relative of the spoonblil, should 
be made. Agoerding to Miah (1932), the Iong-nosed car apewas in lete eprieg and rery earjy oumeor in sarm shoul water, often runaige up wallef stroam In company with the eturgeons. The cese are probbuly attaohed to woods, and the young romaln anong the woed bede dece inchore during thele firat onmeres.

stooks (2007) waye that Palyodon does net spawn in large olear water lakes as does the related gas-plke.

\section{Inding Bablit}

The peenlise fouding babit of the ppoonbill alkes neceseary an setive life fith extenalve jocal algrations in searoh of food. The epoonbild, un11ke other fikh of like eise, does not take other antmale of Jarge alze as food, but subsiste npon wente plent and animal 11fe. Whieh it obtains by atraining enormous quantitles of rater by means of 1te g112 rakers. It wuet be in constant morement when feediag and ita daily loond ditribution mot be affooted by conditions affecting the abundanee of food eupply.

Observetione on the opoonb111's bahartor have threwn some $21 t 61$ e 119ht upon its otrange foeding habite. Whon nomally owimatne forward by the slow eovenente of Its oudal IIn, the peddle- 
fich alterastely briage ite hoad aod padile from left to right, covering atde bund with the tip of Ito saout. Yeediag seene to depend upon the strabing of imense quantities of water wich pase rapidiy into the huge wouth and out through the comb-jike struetures on the large gill site. Loteld ${ }^{2}$ writes of his obgervations. In evimaing, the wouth if hajd wide open without the shythmical reoplratory worements oompon in wout fiahos, though 1t it ocensionally olosed energotically. The plankton (miante plaste and abimal that float in water) to thus strained from the water by 1006 c111-rakers: and Polyodon is a liviag plankton not. It quickly percelves plankton of ground $f 1$ h added to the water of the tenk, and, when feeding, elroles rapiday ore? the we path at times dragging the Jover flas on the botton".

A. Is known, the nost remerkable thing about the seediag habits of the epoonbill is the fact that though living on auddy bottom, It manageg to arold eating mud, and at Yorbes and Mi chardson (1200) have enid. "The relatively ninute eize of many of the objeote on which it feede, the abeenoe of and from the latestine, and ite seeming preferouce for animal

2xoreid, as quoted by C. B. Stockerd (2907) 
food incloate that it is not onjy abje to gather large quantities of very ainute objeote from anons

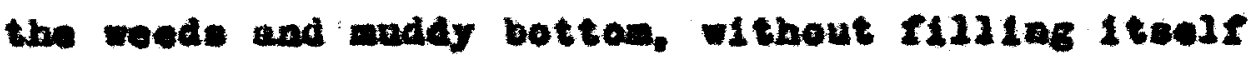
w th wad, but that it oan sopafete the Eatenostrace

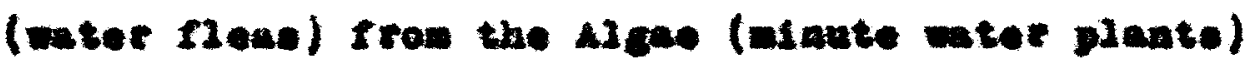
awong wieh thoy awlo".

During the coures of disecotion wo observed

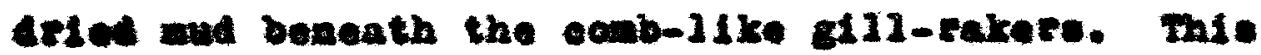
would be a polnt of proot that the apoonb111's comb-11ke rakers cerre os porfect strainare to prerent wad from entering the intestins.

Thes by adjueteant in strueture and habit this grout frob suter fish has cone to eupport Iteolf enticely and ast sucesecruliy upon wriade of tins living organiens that onim in the ater where it IIves.

Coker (1930) eqve a. A. Hetkowakd deteralued the stomeh contente of five spoonbilse tilken by steinghax in Loulelana, at parlous dates from April to Auguet. and found the material to consist

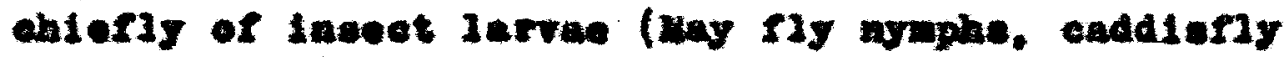

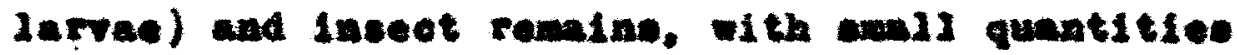
of plant and other debris. Plecos of wood and some paresitie nomatedes wore alce included. The etemach contente of a apoobizl cubutted to the 


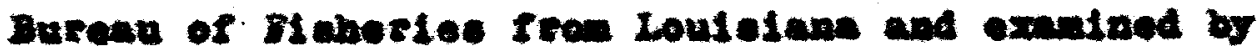
coker (1930) contalned almost exelualfely the polagio and trandincent corethre larves. Seeh observations

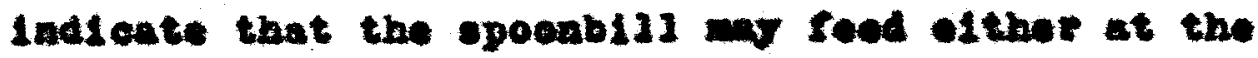
botton of in the vater abore, a watter about which there has been a differenoe of oplinion.

\section{sta}

Peddiorish attaln seot of se, the maximum araliable record being 173 pounde. Heseurements of one meou epecimen will ladicate the proportione or the epectes. Stx feet, two inober in length, this Individual wesured foup foet in its grestest al reunferonoe and wel ghod 150 pounde. Mecording to Cowalach (2933), ususl spolmene seale at thirty to fifty pounde. His Fion differe with cokgr (2030) wo saye these reported eased are rare.

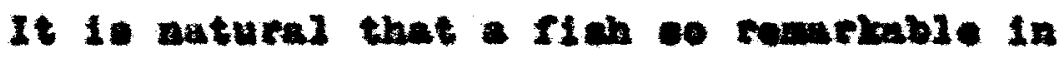
form would at an eariy date attraet attention to the Iow vorld.

J. H. Gomanlach (1933) saye: "Pare varquette In 1673 to 1677 provided what is probably the first meation of this opecies when in the Joedt felatione he saye of lt: near its nose (paddie) is a largo bose sheped like a wasan's beck, three IIngere wide 
and a oublt 20ag, at the ond of which it a ditec as vide as ones hant.

- Najbau wo vefictandy deneribed the pacderial in 1702 thought it wa obort". Benation

Frow perwonal experience, it woens that the epoonb121 feede mostly at the botton of the water. An wah so twenty feet of reel oord had to be noed betore any bites of the epoonbill eould be redt. It is Interestiag to note that the resotion taken by the spoesolil is peoulier. It ofll ake ono attempt to onoepe and thon rensin notlentese for several ulutes. It deas not pat up a batele as does the earp or trout. The roaction of the epoonb111 eppeare to be sinliar to that of the nounder or pores.

Hasearef (1011) decertbet the action of the oponb111 at olose range, durlag a gatoh of different epectes of ganolds. "As the selne lo gradunlly wound up and the fich becose confined to natrower and naxrower opaoe they dart wilely about ceeking wans of - ceape. Oes may thon otudy the opoosb121 at rery elese range. It sente of elght to peoriy ceveloped a on might infer fros ite anil beady black eyee. 


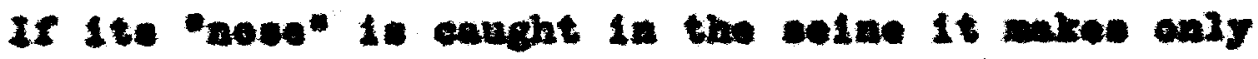
reeble efforts to free 1taed and urwaliy falle to do co. The contraet betwoen the elvelmese of the opoonbsil and the alertnges of an actire rish 10 otrikingly brought out if a gar pize is taken in the cane havl; for the gat nake trenondout offorte to escape sad unlese rendered unconed ous by alow with a wallet. w112 neab through the

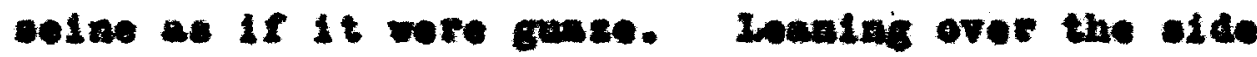
of the bost, neaf the corkline of the celne, one ay wel we a five foot paddiefioh by the nowe (pedde) or tho tall and boul it inte tho bot; the onjy reeletanoe is that of welght. The finh has abooIutely no eport value*.

hocording to ored reporte of severel fieh deajere of Louleville, Kentucky, the spoonbll1 does put up a battle at times. Its ohlef meapon of defonce It the eavded portion of ite body. Whioh it oun owing around freoly (beousu it bas a cartilagInous epinal ooluma) and etrike its opponent. Thor roport ite ctriking lo painful enough to allow the eseape of the fiab. or coures, the atze of the opoonbill voujd detornine it renetion during a catoh. The abore etetoments coen to contradlot Haperkof's ceocription of une outeh of the opoonb121. 
De ar oonelude that al though the opoonbl21 hee no eport ralue, it at leat wares one attampt to renet rolontiy in erdet to enoape. and thus wowe nore reciotenes that werely ite watght.

Aceorlsn to thentrof (1921). the opoonb111

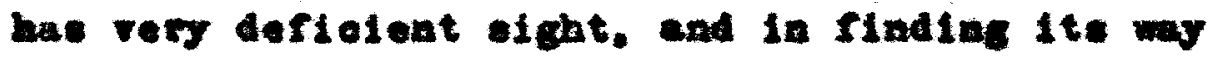
(movenent) it depende ohieriy upon the dejleate

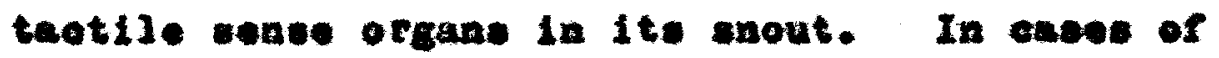
this kind the consery woraing wigt wall oem too 1ate to arve the unout; In faot, Inetenoe are artop coen in which the enout is weet ooupletely broken off. stoekned (2907) obearved a wal-cond1t1oned opoonb131 thet had lout the greuter part of 1te ot12*. but that oridentay hod ourrived and Grow without 1 t.

Mrthes ranoule Uen.

Acoerdins to sverman (1902) one of the

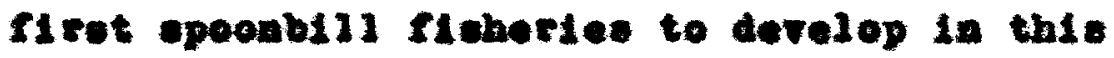
country was that of Lousar111e. Bontualy, on the

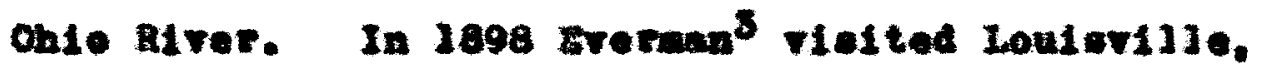
where the Ithernen were oatchlas considereble numbers orety epring. to eare they were ought

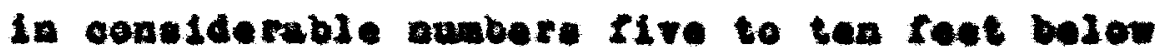
the ourreo of the water. coles (1030), ary they are bot found at leat tan foet of nore bulow the 
oufface. The depth, I beliere, at which spoonbilis se eaught ay vary with the abundanes of epoobbilis. woath of the year, and the tide of the rirer.

As Inoteaslag nembere of opoonbl11: have been cangt by the variou fioheried, further econonis uses have developed. In outting up the peddiefion the boads and fins ere usually disected but conotives they are bolled for 011. Roe is semoved to be prepared for carlax. It walghe Irou two to twolve of fifteen pounde in single fich. It is put on a course wire stere and rubbed by hand serese the wiree unt12 the egge are separated frow their mobrranes and drepped lato the buoket honeath the olere. Itre egce are creontwh black in oolor, wout three times the else of whed egen, and are very nunorous. The ren caviar is then alxed vith cbermen" salt and is rosdy for chipwent. It wat underge ot111 further preparation before it in in the form ramliat to a. In Ito rav atate it was valued at Iifty cents - pound (1010). Luring the poedd Far it mat ralued at three dollare pound. To dete (2034) 1 to value

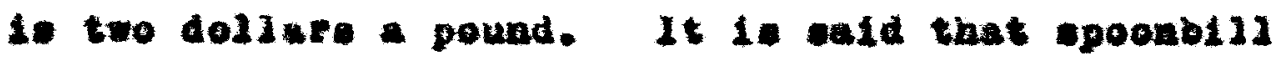
eaviar is the best known, baving reoulted the bighent anterd at one of the world expositions. Hean the figuree brought tegother by sette 
(1925). It appeare that the padilofich, after a merked decline following the ceanes year of 1899.

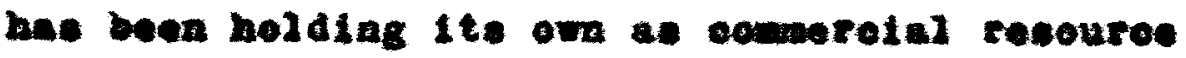
of the Miselselppi bauln.

In regard to the prioe of apoonbill meat, coode (1003) etetes that it it generally cojd at four ceate a pound". To date (1934) the ment of the fleh sile at twonty conte a pound. Tats result in slee of pries indloates the epoogbill to be lase oommon of more in denand than in rowner years.

gusanx

Dy way of sumery we can ouy that the paddefich of pooub121, though not migrating in a large a number a in formor years, is atijl as Ieportant produet of the oameresal ribherfes or

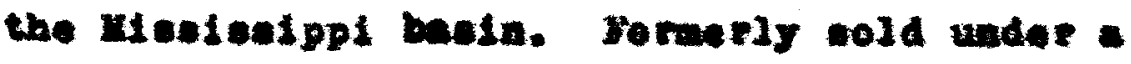
falee nome. It has now com to stand on its own morite. Sutherwore lte roe has value for the produetion of caviat. The beeding of opoon-

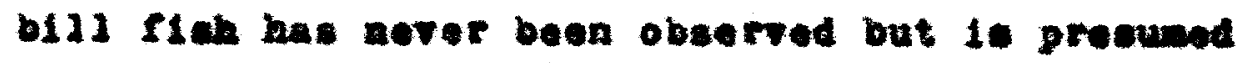
to coent in canj opring. 


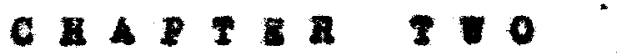

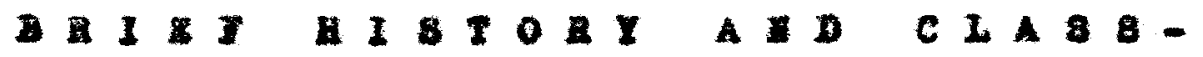

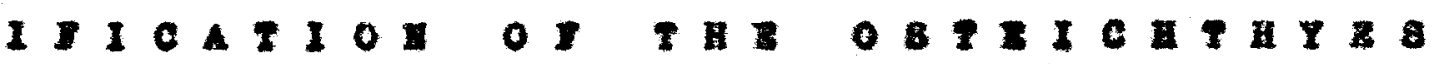

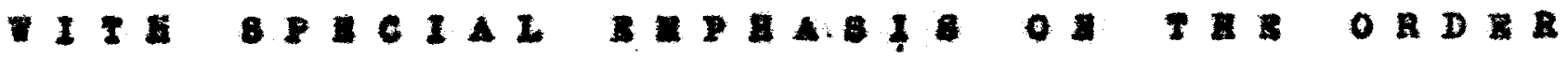

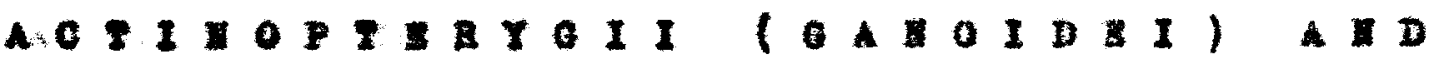

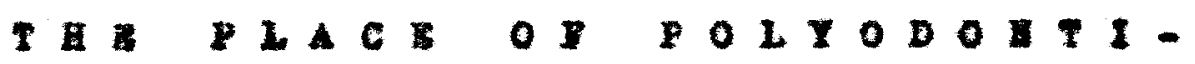
B A A 


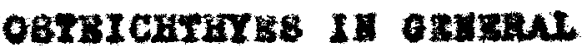

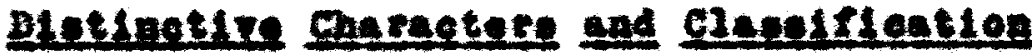

The Oetalahthyos of bony Itohes are those in

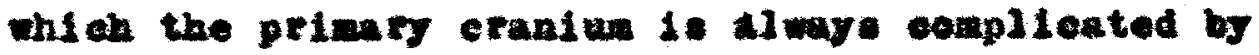
the addition of inresting bones, some of whin at in etregeono ay eceodar13y dionppear. of which pais of parletalo and one of the frontele abore.and tinpelred rower and paraphenold below are the wot

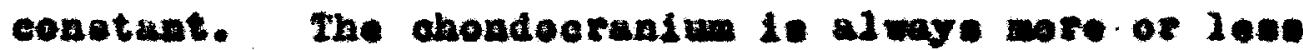

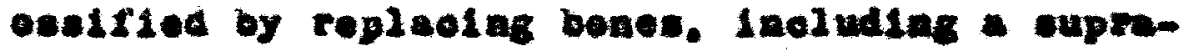
ooelp1tol; and apper and lower are both bovaded by Invepting bonet.

Lankeeter (1909) Indicater that the Jere aro connected ith the oranian through the Internedia-

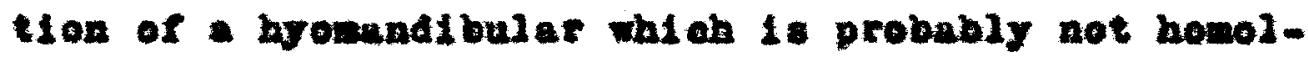

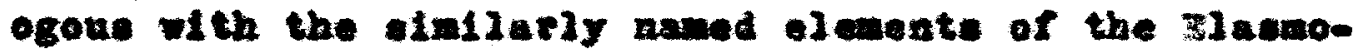
branchs. The dermal finned raye are formed of bones. and are cupperted by pterysiophores wi ah may be

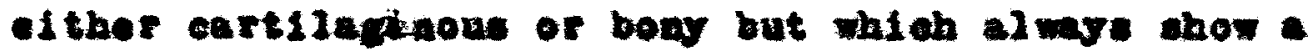
great reduntea in numer se congared aith the honolosove etrueture in il tamobranche.

Ges of the oartilaginous of bony elenente by which the raye of the $f i n$ of the floh are appotted: radial. an estinost. 
The primary choulder ardie io oomplisated by the addition of inresting bones, of wich a large elaviele it the noet oonotant. nu paivte gtrde is vesticted of abeent. The pelvie fine usualis undergo a forward diepingemont, that poeltion bolng -1 thor abdoninal. 1. A.. betwen the ache and peotoral region, of thorade. 1. A., In the pestoral ragios, of jugular, 1. e.. under the throat. A dermal exockedeton is usuadjy present. The lateotias wy or way not have a opiral ralve; the anue 1s separate from, and placed in front of. the urianry and geaital apertures. The gille are covered by an oparoulum oupperted by laveoting bonen. and the interbruchied sopte are reduced or absest, so that the giji-filawente are partieliy of wholly free; the hyoldean g112 It roduced of absent. The conue artertoous is cometimes present, canetimos abaent; when it is absent there 1 a large bulbus sortae formed a diletation of the rentral sorta. The proseneephalon be usually a non-nervoue roor;

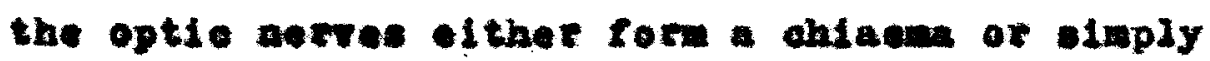
deouscate. The ova are osell; the gonoduote are continuous with the goned of opon anterioriy inte the eoelow of are abrent; in the lapt Inotanes the semal produet: pase out by genltal pores; 
trese ablomiend pores ay be prosent in sddition. sogmentation of the oes is at ther entite. or diceoldal: cerelopment is evortime coedpanted by a entanorphosie.

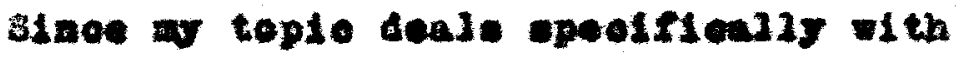
Pelyodon, I aball diseace the opeolal croup hetinopteryeli lacluding the fanlly chondrosteldae

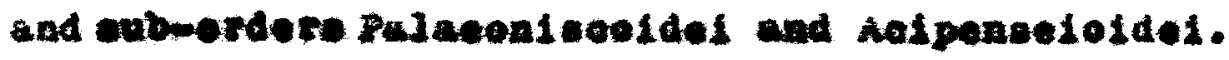
The sub-order Palacondsoolded inedudes the families Platycondes and catopteridac and anb-order dolpeneeroldel inoludes the fandites chondsonteldae and polyodontidue.

These specifie types on serre to show erolutionaty changed in the order hotinopterygil a: wil as to place the partioular fandly polyodon at the heleht of the evolutionury soale preopding the Helostel of next higher erelutionary opeciea.

Briesly the following olsecifieation can be used:

Group or Deder: Aatinoptorgeti sub order 1: Paleopal ceoldae a. Fanily: Platyeonidee b. fanidy: Catoptondae 


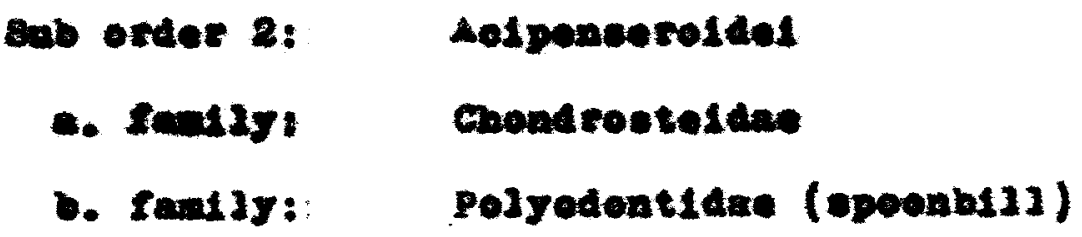

ro roliow the belef olaselfiention ontlined abere:
order:
Aotinopteryeti
Bub order: Palasons seotdes

These are the woot printelve and the carilost or the Aotsnopterygil. They appent in the Lower Doronien period, and are abundant in the Carboalferoue and Pernian perlods, and de out in the Jureselo porid. Whe dermal ckeleton it oovered with ganolne. The seales are ugunily shombold, with articulating pege; but in some (Cocoolopie, Cryphiolepie) the senles ore oylosd and deoply inbrionting on tho trunk, and In Phasecootron the trunk is almost soujedece.

The orbite are for formen and the mont. blunt. so thet the nootelle are lateral of eren rentral. rether than doreal. The soperfieled oranial bones iffer but litele In plen from those of the notwal Teleoutowe. The operoular, oubeperoular, and gulare fore a contianous serles. The orblt lo merounded by a werrov sting of tow bones. Maghromandbular Io eleagatid beokwarie and cennepted with a broed 
ptergede plate. The lowe jor hao dentary. anguler. eplented, and erticuler bones.

\section{Fenily Platgroustine}

In everything but the chape of tho houd and trunk, while beooses very woh compresest and deopened. and the aopoupanyling extonation of the doreal and aned

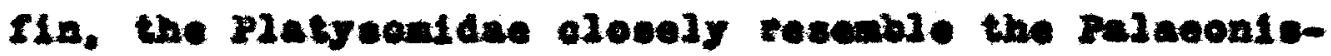
cldev. Iuryeotes, Kosolople, and the Pletrocons are three stages in ahange of form. As the body deepene. the seales becowe tranovereely el onguted. the jawe boove wore polnted, and pelvio fins beeon

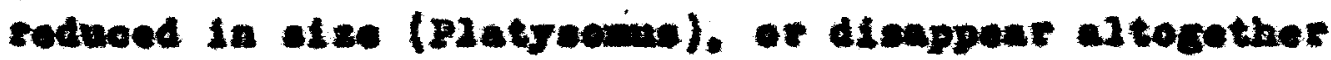
a In chol rodus. The hromand bulat becones noarly vertical, and the nouth is dintulehod. Tho toeth eay be conolderably modifled, booming wollen and eriteraz. In colrodus and chatrodopale the palatal and eplenial teoth fune to grinding pletes. mis fandy is found in the Carboniferous and Permian etrata.

Jouldy Catopteridat

mis type cones from a triesele fantly of funtrorm

Triter - The hat ourface of a teoth devaloped for purposes of trituretion, or grindiag.

Golented - A thin elongated nombrame bone of the lorer jav of nowe roptiles and ganeld fimes. betwoen the ertioniar and dentery (owiled teeth in canolde). 


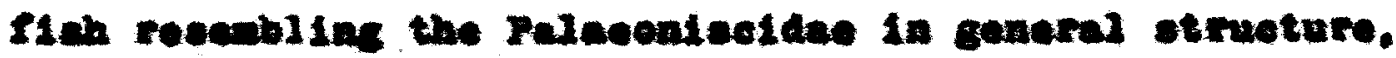
but with an abbreviale hoteroosted tall. The boed and

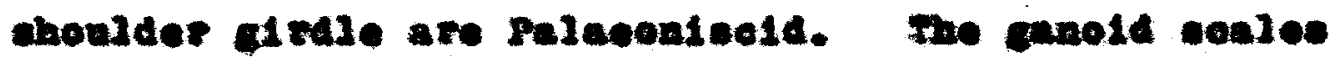
are rhoble; the tooth olender and contend.

. Lakeoter (2900) cwre that wooording to the resecrehes of Tregaits and A. B. Wookwre, the fandiles In this group forn a degenorating certes otarting frow - typo similar to the paleopalsolde; they reach the

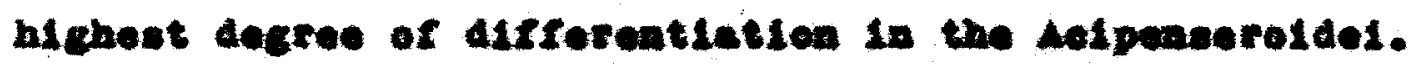

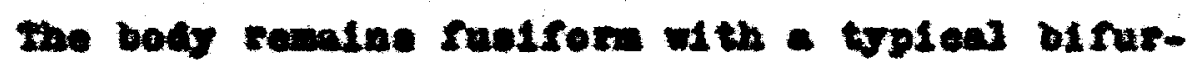
eated boterocereal tell. The dormal and anal $\mathrm{fln}$ are moderately short. The osbles are fap forward, aest the olfectory eapoules. bet the snont beopase sreatly prolonged fros the nouth.

\section{Janily Chomerontelden}

The Chondresteldae contain the nost ancient mow hotinopterye11. The dofinite ansoolation of

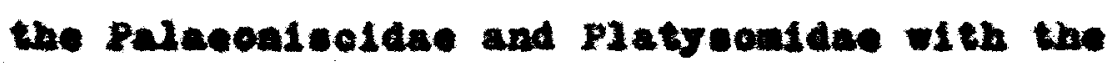
Lotpeneeroldel to dne to rrequalf. One of tho

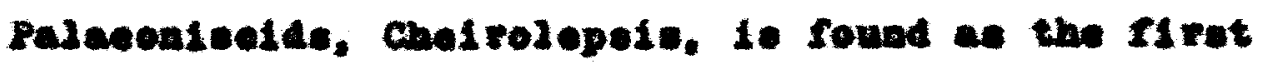


representative in Lower and upper Bevonten sooke. mor ees to bere diverged in three prinetrad

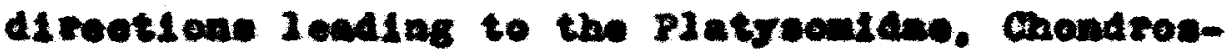
teldae. and catopterydes. The degenerete Ghendrostel are considered to be the only direot sarvivore of the enb-order at the present day. 1. chould be remenbered that the bellef in thole dose efrinity to the Pajacondeolds rests on ezender eridenoe. The whole endeckeleten io Incoupletedy oodfled, remining for the nont part oartilacinous, and in oonsequenes is very Inoompletely known in the extinet opeotes.

The trukk appers to be sealelese: rbomblo gamold cooder are found on the tall onjy. The pal red frontale, partotale, postroatale, and

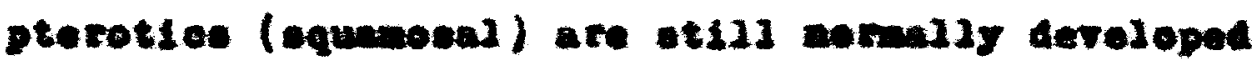
and oot separated by a modias setios.

In this fandly the peoterel Iin has a fatrly normal cheleten, conforming to the ralpidestychous plan, with a rencrible etruoture, difforing frem all other ootelehthres. There it no derint te line of demerntion exieting betweon the pelvie girdie and the okeleten of the ria Iteals.

The radials, forming alngle sontes, are 
articulated to baede which are nore of loge independent poeterierly. but with are rused to the cindse in front.

Dorend procenese. anulogous if not homologous wth the $121 \mathrm{no}$ procese, are drveloped al ong the besel regton of the IIn of the Polyodon. In

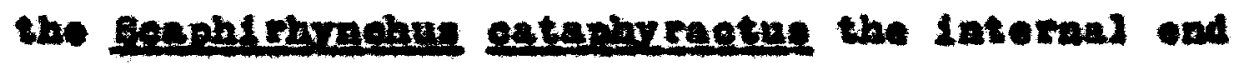
of the pelvie gartilecte way be engmented ort an a epparete ejemont.

\section{Jandly Polyedontiden}

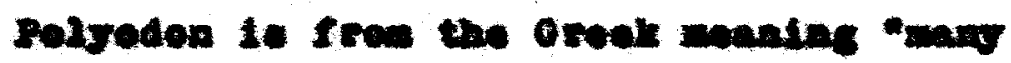
and tookn": but tho and is a alonemer, for thon srow. tho spoonbill bas not a tooth in its bead. Epathula io Latin "opatula". appropriately referring to the blade-1tke saout.

Cowandeeh (2933) cays, "Todny the paddlefioh otands afigle forth smortoan membor, not only of ite fanisy (Polyodontlded) but al wo the

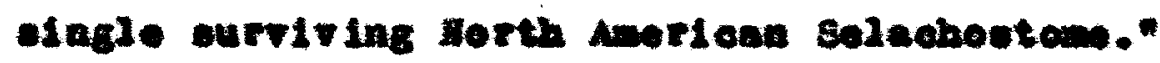

Theer fich have alnete seales on the trunk: andl and sopented in crosoopholls, quite peotletel is Polyodon. 4 cratuonous gonne. Phollduru, alone rotalne the candme (A. S. voodward). in enorwove rlettend restrum with 
rery andi barbels is dereloped in the Polyoten. Jerden (2925) etates that the earond

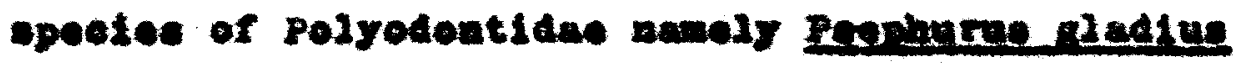

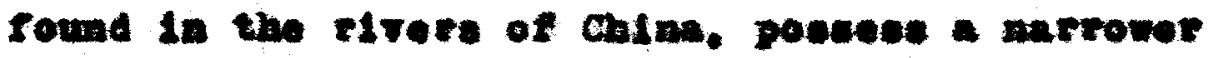

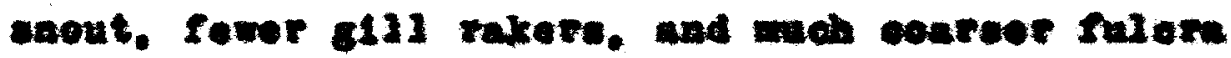
on the tall than does the Anoricen opeoles Pelreden sathule. Goode (1903) wave that Chineas

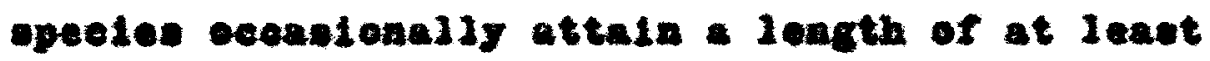
twanty foot, heoording to Jorken, the bablts at far we known are wuok the sane in the two speoses. Howerer. Krle (1926) polate out a differenes. He

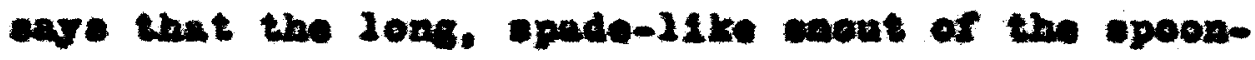
bill 10 supposed to be of ues in ets reing up and wen the fich is soarohing for It: rood. But the opedes that $11 \mathrm{ves}$ in the Chinese vivere is sald not to use ite enout in this way; in faet, the fich epens to be greatiy incontenlenoed by it. Jordon reports the earpe ean stie up the wad wthout a anout.

It way be that through of suse the bill of the Rephurue aladius 112 erentually dieappear. Perbape the sawe w111 alse be true of the Ameteas opoonb121 becauge man forme are found that apper-

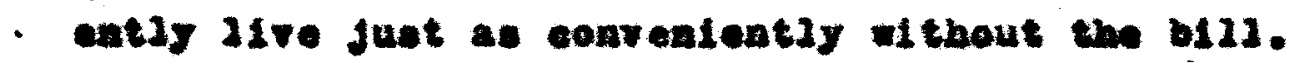
The dotinopteryelf firot appese in the 
eariy bevonian etrate and hare ol bee enerifed

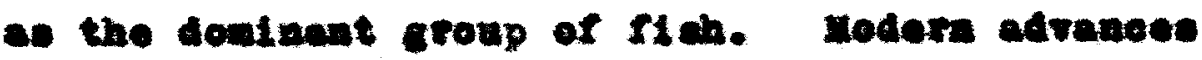
In monedge of atrupture and elaselriention of

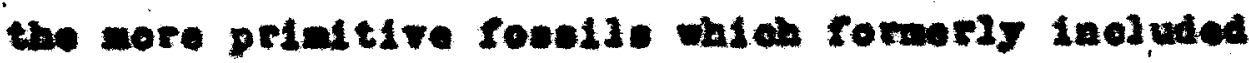
the casoldel are due to ragnet (2908).

The rollowing table how geologionily the phylogeny of the Oatelohthyes frow which the Aetinopteryell have adranced. 
PEXLOGLYY ON THE OSTEICHTHYES FROY IHICH

THE ACTINOPTERYGII HAVE ADVAXCED

\section{RBCZNT}

PLIOCZNE

MTOCaks

gocens

CREAACHOUS

JuAss 10

TARASTC

PERTIAN

CARBOKITEROUS
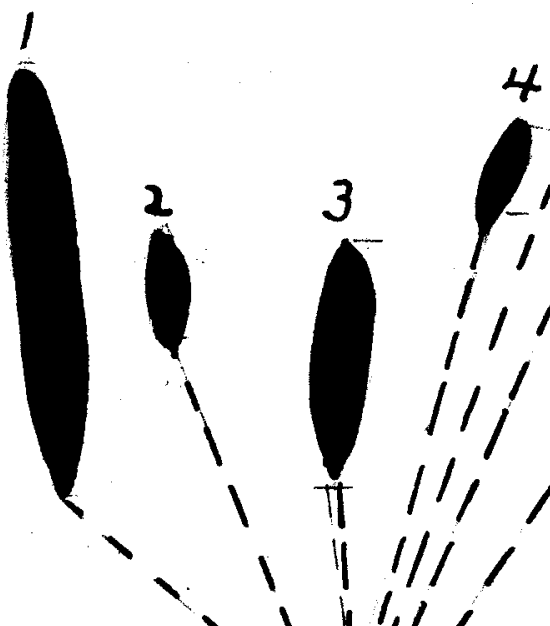

$1 / 1 /$

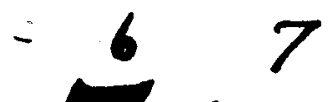




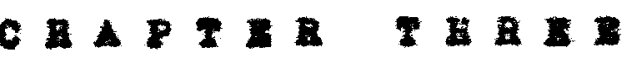

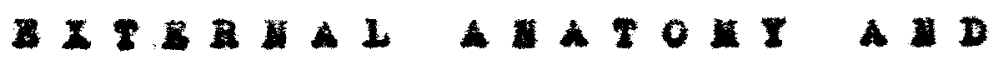

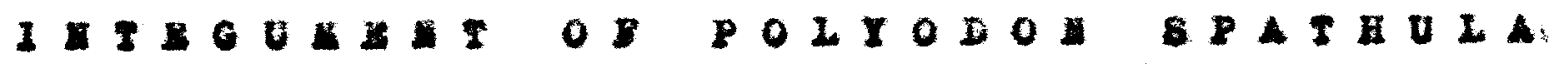

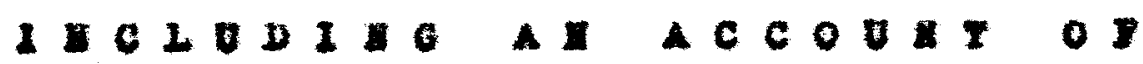

R \&43

A $101 \mathrm{D}$ 


\section{Introduetion}

The body way be divided late three regione! the hoad, trunk, and ta13, the boundary between the Iatter two being tho anue.

Vertebrates which 31 (re in the water differ from those IITing on land in the arrangemont of the body regione. Aguatio animaje mut force tholf way through a donest mediu and henes the forward position of the body is rigld and more of lees wodge-shoped. A true neck region is absent. STen in those mamalo which heve adepted thonoelved to a weliy aquatio iffe. and In the Cotaceans, the nook rogl on it we much reduced that the head and trunk are in direot conteot with ono enother. In every anizal whioh neves rapidiy, howerer. at least one fiexible body region wut be precent where the body can turn when the direetion of morement is to bo ehanged. In the fish this is acoomplished in the oaudej region; In most land animals in the lumber region. 


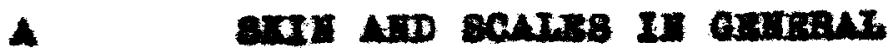

Athough It is a popula bollef that all fichos have eeales, In reality this is not trae. In general. coales apen to be pro-requitst of the nicher of bon

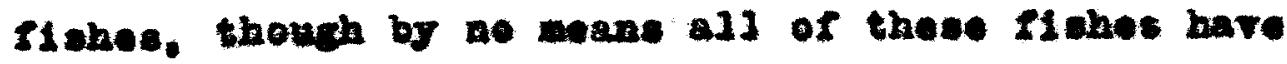

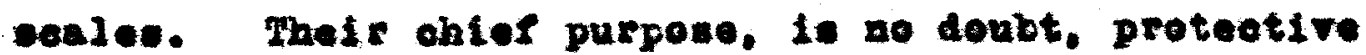
and this is only one of the cereral wey which nature has found for ableriag thet purpose ros different fienes. Bony plates, oplnes, and chagreon are all ade we

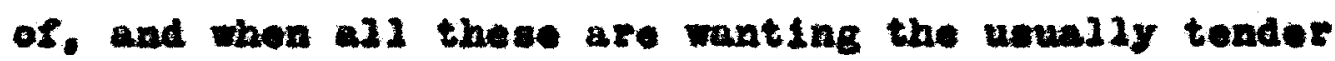

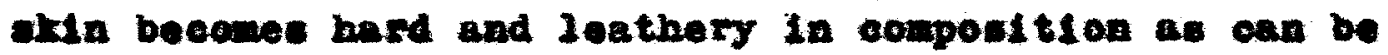
obeerved in the degfich in oontrant with the omooth ektin

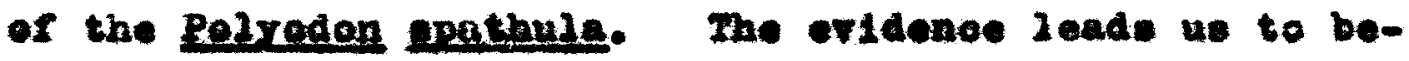
1Lere that wI true fiches have an outer corering of com oet and thet those which appear naked bave lost it. Whaheref one of thee exter protective dertoes nature enploye. they all grow out of the eria 1 teelf. A In other vertebrates, the okin of the riah consiete of twe Inyers. On the outelde lo the opldermis. made up of esveral larere of oelle without bleod reseels, and

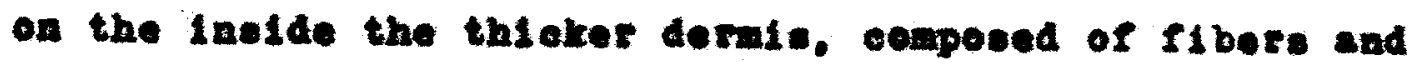
enpplied with blood reseele and nerves. The epldermis 19 almont trancparent, and so coft that friotion will remove tt. H1debrand $(2030)^{7}$ oeys. In the demid. 
Ineldeatly we lind the explemetion of the dietinetire

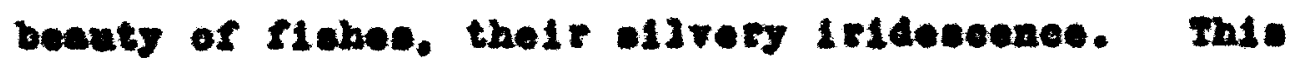
reoulte fron the precenee of elemente alth a remarkable powet of resiceting light oulled iridocytee. Whos thoy oecue in a thick and denes layer, callod ergenteum, on the inaer curface of the okin, they give to the fich ite ollvery apporenes."

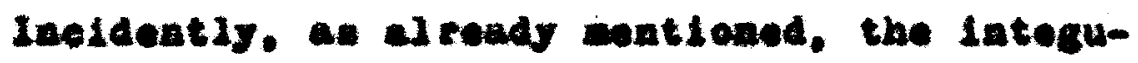
cent of the pelroden spathnie is devold of sealce but

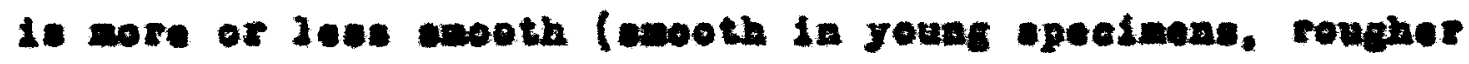
In old specieonel and very little elivery appearanee is shown. It precente ather dudl grey of browich crey coler. Irom this faot we conalude that Relredon stethple has very for of the elemente onlled iridoeyted.

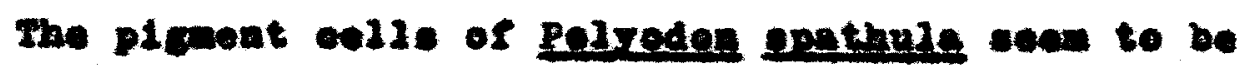
cotivedy tunetioned by celer refleqtion, refiation, and intenelty of coler, both extemejly and in the detais. ben the irideoytes are seattered ofigly they are oufd to euree an IrIdeccenec of play of colora. This faot aloe leads us to conelude that thete are onjy fow

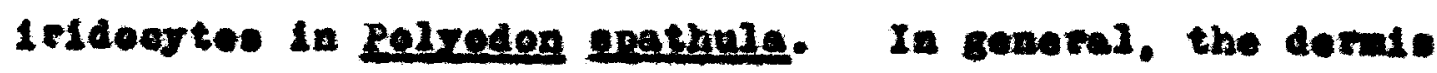

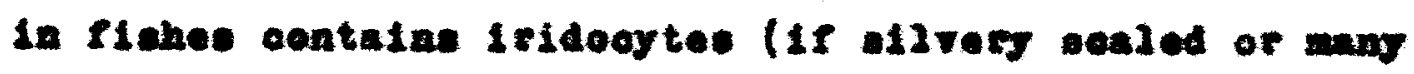
colored) and plgment celle. Some plgment ealle are 
blaok and othere oolored.

Eeales grow out of the dernis beacath the eptderals, but the posterior edge eas projeot to some exteat through the latter. may are thin ealelfied plates, belng more horn-like in compostion than bones and compsrable to human finger nalls. True soaleo in the adult fich alwo overiap one another like chingles on a roof. the outer edget al way belag direeted tomerd the tall of the fish, and the soale in front cevering three-fourthe of the one behind it.

Ones a race of fiaher have dereloped a complete body covering of woeles they may for sowe respon 1050 1t woljy of in part. or they may retaln it only in a degenerate form as oblong plates pertiy embedded in the okin of as amall epines or priokles. The carp (Grocinus egspia) offers an example of a ingle opeoles come nem. bers of which way be completely soaled; othera, wuch as the mirfor carp, only party soaled: and still othera, such as the leather carp. wholly naked. The freah water 0.1. have degenerated soales consisting of oblong plate arranged in groups, set at ight angles to each othor. and partly buried in the akin. Only rery elose examination will show these etructures in the el. The rileFlahes, sowe of the puffere, and certaln coulpine all 


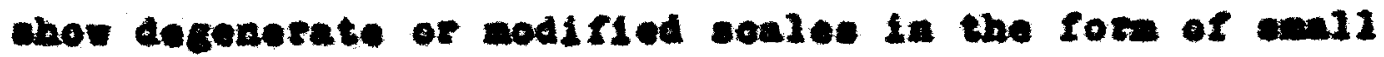
optaes: the porouptne Ith (DLodon brotelx) it an

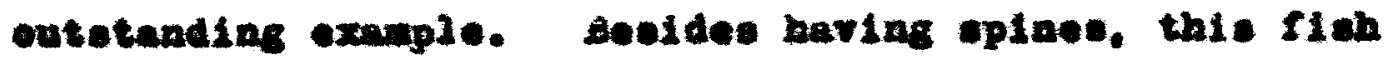
2111. 1teelf with als of weter for protedten.

\section{The subetange gengla}

The vord rengld refere to the abetanos which covere the outer eurface of the bony plater pretesting nemere of thi great group of flabe (rog-itine). This

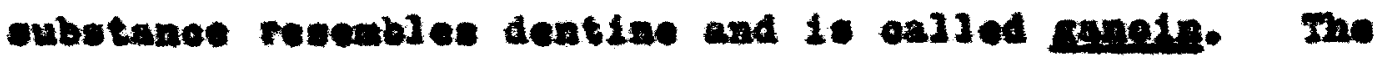
Cunota plates on the Aweriean gef-pike an be taken as the most trpiend example of thi liad of eorering. Tove ero large, bony, teotangular plates arrenged in rowe and placed adge to odge. in coatrate to the orer-

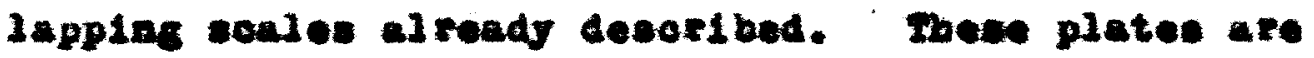
very hard and form an exellent swor. Although interloeted for additional btrougth. theg do not make the body ridid, as they woy ceparete of partiy altde orer ach other when the tibh nores its body from alde te aldi. The tree edcee of the plates are ce abarp that a 1150

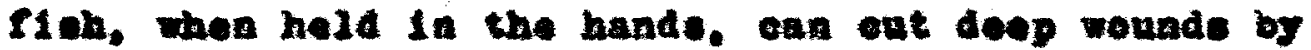

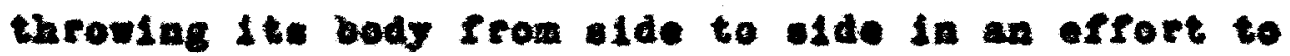
cespe. the reb plachine the hande and fingere betweon 
the meratae of the plates.

In the oturgeons - aseag the largest fishos of our sesshores, riverp, and lakes - the genoid plates ondy partly corer the body. Generally two rowe of plates lit on the buok: one along the alde, and another along the edge of the abdowen. Those parte unpreteeted by shlelds are covered with rough leathery skin. Fin813y in the paddicfichen. Polyodon apathula, the ganold plates have dieappeared entirely, learing the orin aiwost wooth. The Polyoden upathule with 1 to rather delleate bill and anooth okin, eppear, we compared to other ganold fimes, to have rety ilttje protective adeptation. 
- Sxternal Anatony of Polyedon epathrie

Por.

The body of the epoonbstl is compreased latera $3 y$ and io in genersi elongate. Ite watian vidh is that region of the trunk just enterior to the pedple Ina: this body rogion is approxinately ono-aixth ite ent1re length. The head is dopresed sad elongeted. teralnating oateriorly in a sathula-sheped onout. The onout is paddio-shaped as can be seen in the photoeraph (rig. 2). The greatest width of the bill is ite anterior portion. The snout is bellered to have a ensery runction. Protruding frow the head into the bill. the ourtilaginous rostrum oan be folt extending to the tip end of the enout. The restrum is thickent at the posterior portion of the jill and thine out a It goes anterioriy along the nid region of the bill. The lateral portione of the b112 are cort and precent the feeding of a thiok rubber membrane when preseed from the sides.

\section{Punation}

Al though no referenoe has been found pertainIng to the rajation of bill to preseure. we auggeat that alnee the enout is a seneory organ, preseure way 
have an offect on it. Dhon presenre beeceses too great, the bill way wata the fish to ceek o higher 20vel. The ohief funotion of the 20ne opathula, bowerer. 1s to otf $\mathrm{f}$ up the wud, In waleh are found the atante organfens on whitoh the fiah foede. Dader the paddle ere two palre of almute berbel corresponding to those of the sturgeen. The lone and aleader gill rakere enrve to etrein the food (wotre.

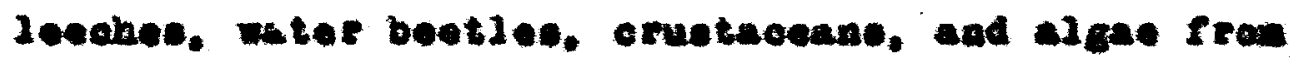
the wad watere from which they are teken). AcoordIng to Jordon (2007) the wost inportant part of theit

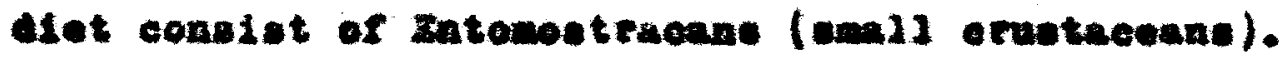

\section{ener.}

The color of the spoobill raties on its difforent ourfeose. The doreal aurface is dafk grey, the lateral, rariation to a greylih brown color. and the restral oueface. Iight browa exoept for the belly enrenes walah is wite (rig. 2 ).

\section{rns}

The flat are rlattened outgromthe of the body. They are eupported by laternal cartilaginono rode and the dermel fin-raye. Both the cartilaginone and des-

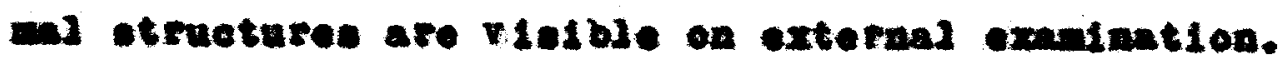


the fine are of two types: codien and palred. The palred fins are homologue to the patred 1 imbs of higher rertebrates, although the akeletul aleante chorateriotio of higher rertebrates are lacking in Pelredon spathuza. A11 the fine are non-jobste. The modian fins wijl be described flrat. Thare lo only one doral fin, the posterior dorew In, looated on the mid-doreal line of the body.

The tall or oaudes IIn in of the hoterooercal type. The lobes of the tail are of unequil sice, the coras lobe belng larger. The keletal axis of the tall bende upward and entere the doreal jobe. Tho oavdal fin helpo proped the fiah forward and aid it in sudden changes of cirection.

A camere Ineida drafing $(28 x)$ is shown of the caudal fin of Polyoden gngthula (IIg. 3). It showe the oartilaginous and dermal portions of the caudal rib. The opiny etrubtures, the fulera, are ceen anterior to the dorsal lobe of the tall.

The and In 210 imediately posterior to the and aperture; It is median and projeots in a caudal direction. It ends in a convex fan-ghaped atructure.

the peitod fles

The pectored fine are paired and rentrally 
10oated. Thor are fan-obaped and attached to the rentral eurfuce of the body juet posterier to the operoulus. The peetoral fine funotion in controlling the horlzental poeition of the body in the water. The pelvie rine are broad and contex ehaped at the end. They are atteched to the rentral surface of the body, about an ineh aterior to the anal aperture. Thoy are horizontally attached and point in a rentro-jateral direotion. In Function they work in conjunction il the peoteral

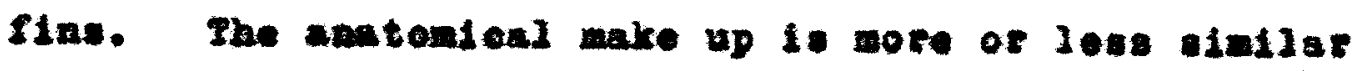
in all the flas of the spoobill.

\section{Aportures}

The woutb, as in islaomobranohs, is loogted on the reatral oide of the head. It lies immodiately ventral and posterior to the bijl. It is large and horwewo ahaped (IIg. 4). In the adult Relrodon pathula teoth are lacking entirely. Howeref, in young opeolwene amall bow teoth are present.

The and aperture is large and about an Inch posterior to the peivio fins. It is the outlet of the produots of the digestive traot. The urinogenitel opening Iles immediately posterior to the anal aperture. Through it the produets of the renal and genital organs are discharged. Laterally 
the eye is found just posterior to the onout. It 16 comparatively andi, opherical, and degonerate. It fully ocouplos the sherian socict. The oyeIids are not morable.

\section{Paxes}

The optracles are located about an inct postorior to the eye on the dorso-lateral margin of the head. Thoy are narrow olit-1ike openings. There 1. a patr of oponinge leading to each nasal carity. These are anterlor to the oye and -bout an lach epart and obriously asetet in the cicoulation of the water through these earities. on the doreal aurface the larger palf of external narea are located as elevated beruoturea, dorad and anterior to the eyes. Dony ray-like etructures are preaent dorealiy cerose the head reglon. whoh festure distinguichen it frow the cuerounding plgented ckin area. This ray-2ike atruoture is duo to the 1009 contad of the endonkeleton with the integument.

Ine Leteral Line

This will be disousaed under integuent. Sxternally the oanal is visible junt posterior to the contril and extende sorose the body up into the doraal 
2obe of the tall. Minute pores oan be seon leadIng direetly late the lateral ilne canal iteelf.

The onerenlur

The oporoulun is flechy and forms a pouch11ke fold rentraliy. The outer artace of the operoulum it pigmented with clugter-ilike opoto. Forbes and Richardion (1909) say these oluster-ilke epote of patehes on the opercular flap are belleved to be seneory (InG. 5). Under the operoulat flap. nerging of 9112 openinge, with nemerous corneous megrean-11ke dentioles are seen. The under eurface of the operoulum is mooth and unpigmented. Blood reseale can be seen from the inner ourfece of the operoulus. Herely by pulling the pouah-ilke operoulun upwarde wen the filh 18 laterally plaoed. the g111 etruotures beasath are clearly demonstrated (218. 6). The operouzun contalne no operoular bones and is extended inte pointed process; the branchioategal membrane is continuoue with the operoular and: has no branohiestegal rays.

The Interument

The skin is deroid of acales. However, a few degenerate caleffled structures may oceasionaliy 
be sean on the doreal part of the trunk, and oandal regione, but these are degonerate forad of thonbio coulea. Chromatophoras (brown pigment colls) are preast on the flank and operoulum and are enpecially nume rous on the baek. They are abeent on the bolly region. Oeoasional orange-colored epote are enen anong the chrometophores. These may be large ohromatophores and of different colop. Iumerous ohromatophores are found on the epmthula expeially doreally. The wout alpo has seacory pores. We have beotioned part of the bill and made it traneparent iy treatment in $70 \%$ woohol, followed by Lmoraing in Beeokwood ereosote. A ommere Iuolda drawing (28x) was me (F1g. 7). The same propedure was followed for section of integument from the dorsal ourface, belly surface, and flank of the fiah (IIE. 8. three viewe).

A ecetion of integument was taken from the trunk region including the lateral line canal. Doreal and especialiy reatral to the lateral line are finger-like lobet whiob lead to the maln canal of the lateral line aysten (rks, o). mese lobeIike projeotione are seasory in funetion, belng connected to the lateral line aratem. Thoy are dietributed along the lateral line oamal and can 
be followed to the doreal surface of the hoad, ending in a definite path at the nostril regioa. These struetures are lose numerous in the candal part of the epoonbill. A few of these censory otfuctures oan be traced formard on the surface of the bill (renteal and dorand) in large opoonbise.

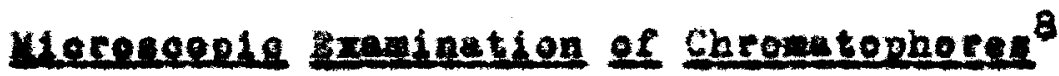

Cellotdin erogs sections, 40 mierons, of the integureat of the snterior trunk region foxoluding the lateral line eanal) were made, and stalned by the hematoxy2la and coein wothod, as outilaed by ouyer (1932). The ehromatophores were of a browaluh color and arranged in two rowe for the moat part, al though a fer chromatophores were ceen soattered botween these two rowe. In the epidernd the ohromatepheres, eppeared anall. -pherical and light brown. In the dovais tho ahromatophores were more or lens utedlate-shaped. isrge and dark brown.

Cejloldin orose cections (40 merone) Irew the aid-doced body wall, Including the lategument, ansole, and conneotive tisene were prepured - abere. It wa observed that in the opidermis 
the ohromatophores were sall and sphertoulaboped, but the color varied, thut 1s, alternating from a 11 ght to deck browa. The Jarger stellate-shaped ehromatophores were more or leat equaliy dietribnted in tho dermis, extending down adjepent to the ausole and eopneotive theoue, but not arranged in any derinite row. sectlons of lateguneat ( 40 alocons) fron the afd-trunk region, ineluding the jateral-11ne canal, were also prepsed. Numerous and I sherieal browniah chromstophores wore oon in the oplderais and fow in the dermia. Tho large otellate-bheped ohromatophores were absent. exoept for fow that appeared sround the lateral Ine oaned. 
The wanoud features of the oxternel andany of the epoonblil way bo demosetreted by a conparison with another ganold, the needlerieh, Byloourus longi reotrua. The following ten points will cerre to emphanize these differenees (Mig. 10):

Rozredon engthula

(apoonb111)

1. Bill onde horee-whoe shaped and extende beyond the mouth. Youth is posterior and rentral to the b12.

2. Bill considered sens-

3. gasl, rather degenerete eyes. opherieal and ventral to neal aperture. ory in funotion.

3rjosures Iongl rootirea (noedzerion)

1. Harrew bill conposed of ganoln. Upper and lewer billa Inolude the wouth.

2. B23 1 is not sensory in funotion.

3. Very 2arge, effioleat opherioal eyen. reptral to the naeal aperture.

4. Large posterior project- 4. Rounded operoulum. ling flechy operoulu 
Pelyedon Anothula

(spoonbi22)

5. Peoteral eine rentral-

Iy loceted and nox-iobate.

6. Hasel apertures

paired and amall (two peira).

7. Smooth ekin lexoept

- fow degenerate ceales in caudal recion).

8. Body compreosed lateraliy

as In the peroh.

9. Heterecereal tail.

10. Absence of true teeth in adult state.

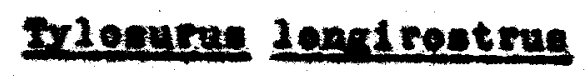
(needierioh)

5. Peetorad fine lateraly joeated and nom1obate.

6. Facal aperturee large and ingle lone pa(t).

7. Smooth okin but rougher than the opeonb111.

8. Cylinder-shaped body and longated ss in the eel.

9. Honecereal tall. 20. Nume rous need 1031ke teeth present. 


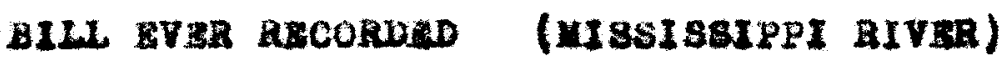

Thompeon (1933) reporte to beve obtalned ceven amal1 canold tiohes ranglag in olze from 17

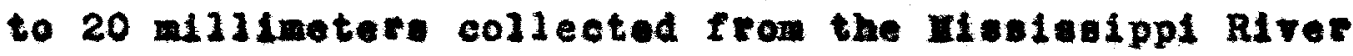
near frend rewere. 1211nole. Theese have been tdent t1ed as young of Ralrodon santhule. These postIarre of Polyoden were reported to be pale and translueent and wo amall that most of thom foll through the meabes of the selne and inte the sand as lt wa havied frow the water. The water timperature wes about $55^{\circ}$. Your of the epeotment were preatred immediately in sos alechol and. the other three preaerved in formalin. Dravinge of the emajleat of the latter $(27 \mathrm{mo})$ and of a $200 \mathrm{~mm}$. opeolnen made by ue. Yohr. are shown in 51 gare 12 . in order to auggest the atritIng change in extermal appearance of the fioh. The reader may wonder why it has taken a ountury to secure a fow smali apecimens of this conepleuoue and oomon fish of the Hiesieatppl River. Thompeos (2933) explatie that this acanty yitid eesen to be abeodsted wh the fact that the spaming take place. and the young grow up in the ewift and turbid 


\author{
pertione of the nain ahannel of the Herielppi. \\ where blelogleal phenomena of all eart: are largely \\ - sght unesn*. The eridence inalatee that the \\ opoonbl11 migrates extenelvely through a wide variety \\ of large plrert und bottomland lakes, habitate all \\ of which sre more or leas ingecesable to tackle \\ ued for coljeoting such material. It also semo \\ 11kely that the mot dentrable otages are pased \\ winta a fov deye or weeks time.
}


D

보.

It hould be mentioned at this tine that fron all external appearance the $\operatorname{man} 1 \mathrm{~s}$ and fomalo apoonb 11 cannot be diatingulahed frop each other. Eren in the spaming sesson one cannot differentiate the male from the female. The almilarity between the two sexes during the spawning eason is becues of the great abdontand aletencion in the male due to the fat that colleata about the tester et this time.

Steckard (1007) aleousees this point. "Yo indicetion of cemal dimorpht oould be detected. the males and females belng indistingulshable in theis color. ata, and chape, and in the proportion of their external body appendages. A fanale with her ovaries filled with egge of the seseon was uoually recognized by the diotended condition of the abdomen. and yet eren this distended condition of the abdowen was not alway. valid aince the males when fat and in good oondition hare co extensire mas of adipose tiseue about the testes that thej abdomen is dimost equaliy ewollen. The fat about the testes 
of one male we found to welgh three and threequartere pounde."

Wo chould also take into acoount that a poorly fod fomale apoonbili may be mistaken for a male. The oxly way to definitely deternine the eex of a spoombill is to study ite reproduotive aystem, and look for the presenoe of roe in the mare spetimon.

A11en (191i) eaye he hat neres ceen exually mature Polyoden weighing lege than fifteen or twonty pounde. 


$$
\text { C A P I R P O U R }
$$

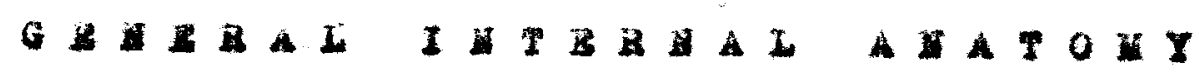




\section{- Rerlcerarel centon}

The coplea of body oavity is large and well dereloped eren in the lowegt of rertebrates. In the opoombill as ia other fiah the coelon is divided into two parte: the pericardial cavity containing the heart, and the abdominal or peritoneal oarity containing the plecera. The perioardal oavity. wioh lles just aterior to the pecteral girdle. Is triangular in chape with 1 ta apex at the anterior end. The shape of the pericardial cavity of the spoonbill differe fros that of mamal beosuse of the shape of the heart. The heart in widest at the bese ind astrowe dightly at the apex, the opposite to the manwallan heart. The henrt is oovered with the visceral pericerdiua. The parietal porleardiun which linea the oarity is amooth and rather tough wombrane.

There are no mesocardia in the adult spoonbill. The heart is attached to the wall of the pericardial eavity at the anterior end by the conus arteriosus and at the posterior end by the inus venosus. At thene two pointe onjy are the vieceral and parletal perloardie continuous. 
- Tas Abdoningl cealon

The abdoalnal earity is bounded anteriorly by the traneveres septum juet posterier to the perieardial seo. The tranoreres soptum epperates the abdominal fro the periesrilal oevity. The abdominal cavity extends to a point juet posterior to the anal sperture. It it lined throughout by a membrane, the parietal peritonew, which forme the mooth wall of the cavity, adheriag rery closely to the muscles of the body wall. It is morphologieally equivelent to the parietel pericardiun. The parietal peritoneun is a tougher membrane than the parietal pericardium. In studying the relative alzes of the abdominal and perieardial carities, we found during the disection that the pericardial oavity measured approximately ono-halt Inch in length wherea the abdoninal carity measured alx inches in Jength. giving a proportion of one to twelve.

C The Abdeminal Viecere

the viseere will be discused under indi-ridual byotems. However, the following organe erm 
exposed wen the abdeninal eavity is opened. The IIver is a large browala gland in the anterior region of the coelom. It is composed of a long right and 3eft lobe and anch dirided madian 20be. Between the wargins of the right and median lober the cral bladder is located. It is thin walled and almost completely spherioal. If the caceun is raised the atowach 1s seen. It is shaped like an inverted letter "J". The curved portion lies below the liver and the straightened portion along the body wall. The large fanshaped cascum is divided into several lobes. It is attaghed to the phort duodenum. Posteplot to the dadenum is the ileum or valvular inteotine. The ileum narrow into the short, rather wide rectum. The rectum leads to the exterior or anal aperture.

The triangular shaped epleen elongates posteriorly ending at the mid portion of the 1leum. It Iles between the curvature of the short duodenue and tine llewn. Large blood resecl run to the spleon. The dorael acts also orosses the body carlty and enter the mesenteries neaf the 11 rer.

The teproductive organe in the speciment evallablo were immature and therefore mall and con- 
cealed by the other abdomined viaeera.

The kidnore are retro-peritonesl and elongato.

\section{The Henterles}

The viscera are held in place by a number of foldo of the peritoneum, the gesanteries. These membrapes are delicate. The doral meentery doee not attach itgelf to the entire digentive tract. It is attached to the stomach. duodenum and cuecum, but not attached to the oesophagus, 1leum, and rectum. A membrane conneets the splean and lleum; this is the 11 eno-resenteric 11 gament. The 1 iver is conneded to the 1000 of the storach by the Eastro-nepatio 11gement. and to the oesophagus by the hepato-oesophageal Iigarent. At the junction of the otomach and duem denum a membrane is attached to the liver. This is the hepato-duodenal onentum. The portion of the doral medentery apporting the valvular inteatine (ilenu) is the mesentery proper. The anterior end of the ifref is attached to the rentral body wall by the suepeneery of faloiform 11ganent, which is only one centineter long. This 1 a ahort remant of a veatral mesentery extending from the old-rentral wall of the coeloa to the aid-ventral curface of the 1iver. 


$$
\text { C HA P } \mathrm{T} \text { I } \mathrm{Y}
$$

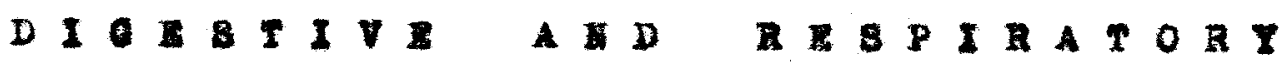$$
\text { 8 } 1548
$$ 


\section{A. REGIONS OF THE AI.IMEITARY maOT}

The venteal wouth is the region extending from the IIp. to the pheryax. It is more of lees Meshy. Enoreoue of mouth but wonk of jaw, the paddefich when

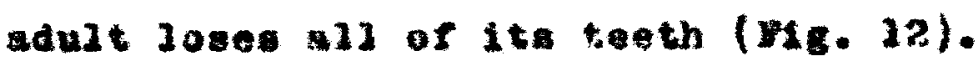

It is interenting to note that the ganosd

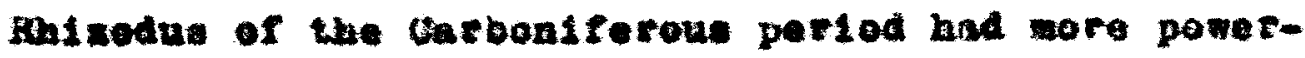
ful teeth than any animed over known, oberper that and four times as large as the largeat living erocodile posenesere.

ginos the epoobill supporte iteelf entirely by straining minute plants and animals (plaskton) from the eurrounding gediut, it is not surprising to Ind that the pharyex conting en ejeborate syeted of etruetures. The pharynx is the region eurrounded and aupported by the fite patrs of branchisi arehes. It Is piarced oy the piracies daralizy, and by the five searly somi-eireujarly phsyngeal olefte later11y. The branohlal arohos extend forward ia an antera-modisl dirootion on both the dorsal sand vediral gices of the phrzynx. Dortally the gill wahes fuse in a ald-dorgal eartilaglaous bar, part of the viseceral sreh. Posterior to the vieceral aroh the 
pharyax broaderie into a triangular fiechy mase. on the rentral side of the pharynx the five pairo of branchlal arches also fuse in a wi-reatral cartilaginous rod. the basi-beanohiel cartinge, part of the Fisceral arch. On each 6112 arch there is a double veries of fine, oomb-1ike gill-rakers, which are long. slender and exoedingly numerous. A more complete deceription of the etruotures coineeted with the 8111 arohes appesce below in connection with the resplratory organs and the vieceral keleton. Tho fifth visoeral arch. which to much reduced in stat and beare no gili

' fllaments. extende down to the beginning of the oeaphagus.

The oesophagus ia the first tube-1ike atructure of the algentive syatem through which the food pasees. To the ald-doreal eurface of the cesophagua the large cucumber-ebaped sin-bladder is attaobs by the doreal mesentery: and posterioriy the swim-biadder is diractIy connected to the oevophagus by the pneunatic duct. Another duet at the anterior part of the owim-bladder 18 present but reatigial, of at any rate 1 sot nearIy so large as the posterior pneumatio duot. It an be eaid. then, that the swim-bladder of the spoonbil3 posaresea two pneunatio dueta: the poaterior duot alearly shown and the anterior duet. which io vectigial. 
This pecles has partioulaely large enta-bladder - campared with other gano1ds. The amim-bladder is - hydrostatio organ. Since the avim-biadier opane di rectiy into the oesophegus, afr can be taken in direotly througin the moutin. This elasees the soonbill with the phycostomous group of fishes. 20 while the awim-bladder of flahe (pheumatoogst) is not ordinarily considered a reoplratory organ, its poesible relatione to the lunge of higher vertobrated make it poasible to consider it a reaplratory a well ac a aydrostatio organ. Doraalyy it is attached to the doreal body wall.

The American gar-plye of the family Lepidostidae ha a subdivided fim-bisdder usad in reapleation. - The owim-bladder of the gar-pikg is muscular. freely supplied wh blood from the sorti. divided Into cella Ilke the lung of a reptile by ereulat bundles and opening into the throat by a wide duct (pneumatic) and long slit guarded oy sphincter maselen. 11

In the epoonbili. the enta-bladder 18 more merbanoue than useular and has a comparatively poor blood eupply. Thio faot indicates that the spoonbili has rety little uoe of the swim-bladder in reapiration. The aoft fleahy oesophagua leade to the hard

\footnotetext{
20ralter (2020). (p.371), Includes the bony ganolde. Bppet and cort reyed releoste in the Phroetoni group

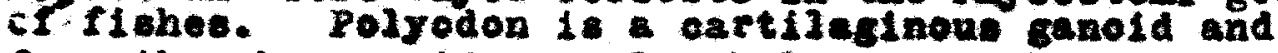
from the bote oridance al be belonge to the group Phyoostont. 
and widened poction of the digeetive traet. the ctamech. The eardite portion of the btoman 10 atralght and curves to become the rundio portion of the stomash. The stomach becones lacb-11ke in atructure at its pyloplo portion jugt before it conatriots to form the pylorie sphincter. Fosterior to the pyloric ephineter is the ahort duodenum. or

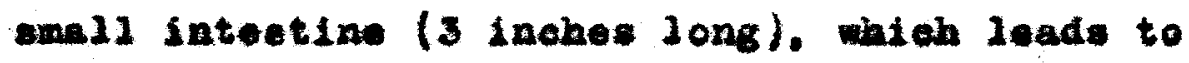
the ilaum of valvular intestine. which end in the ahort, wide reotum, followed by an opening the anal eperture. bigures 13 and 34 show digentive tract. The eplral valve in polyoden oonelete of about even fold of epiralo but are not nearly as well developed as they are in Blasmobranchs. Surface aboorption is alded by the pyloric caecum in Polyodon as well ae by the valrular inteatine. The pylorie caeoum $\mathbf{1 1 1}$ be discuseed under the topio pertaining to Elands.

- Hodular marking were present on the oaecun. ctonaoh. and duodenum, but abeent on the oesophagus. 1 Ieum and rectum. When these nodular etruotures on the etomato. osecum, and duodenum were cut open, amall nematode worme were remored. These nematodea chowed paragitic infection of parta of the digertire trest. These nodular atructures were seen on other 
upeonb132: and on the sane ergane: nene1y. the oesophagus. cacoum, and duedonum. In one instanee. two tape-wermo wore lodged in the abdominel oarity. and not in any partieular organ. These cettode parasites, Dibethruim hastatum, 12 were three to four Inches long.

12gtegmed (1007) quotes Uinton for the above olsesIt lation of the tapo-vorm. 


\section{B IATMRHAL STRUCTURE OF TEB DIGESTIVR TRACT}

The wucous lining of the oenophague, when exposed present numerous large fluffy papliat at its anterior portion. Pooterior to the papiline many long. Alender folds celled rugae are present. These rugae become Jarger and fewer the polnt where the cardiac end of the stomach bogins. The muscular wallo of the elongated stomen thioken posteriorly and the gastric carity becomes sealler. The hort duodenal portion aloo has thick muscular wall and a mall cority leading to the lleum. The lleum or colon has a opleal ralve hich enlarges the surface of the integtine for sborption. Along the reotum a few folds can be seen that extend in a longitudinal airection: these are the rectal folds. The eacum when cut open presenta a soft spongy mase; this is glandular tisaus.

Numerous newatodes were taken froin the muoous layer of the stomach and from the partialiy digented food material. In one specinen forty-three nomatodes wore lodged in the stomach, ten in the duodenum and five in the eaccum. This liage number of nomatoden shows that the stomach of the apoonbill is the favorable place for namatode infection. 
c

OLAIDS

\section{Gecente}

An evolutionary afgifleance can be observed In the pylorte caeca of ganolde. This in discuesed by walter (1029). "The gasolde in general show a transitional condition by the presence of a degeneratIng epleal ralve, along with the introduetion at the same tiwe of 'pylorio cacen'. which in higher fishen take the plece of an elanmobranchian opiral ralve as a device for endarging the internal surface of the food tube."

Attaghed to the duodenum io the large pylorie cacour. It is difided late sereral lobe-ilke portions ridged at the ends. The number of lobes varies in different specimen of the same species. The pylorie cascus is part of the digotive tract and 1. uned as an organ of algestion in the spoonb111. It is not a rudimentary organ as is the appendix in man. By cutting away a plece of caecum and equaezing the remainder, one oan see partially digested sood oozing out.

Alexander (1915) gays the pylorte caeoun of the opoonbill has been formed phylogenetioally by sereral small pyloric caeca beconing confluent at the bace. 


\section{Liver}

The liver attaches itoelf to the rontral and anterior portion of the oesophague by means of a 11 ganent, the hopato-0osophageal 11 geaent. As stated. the liver conslete of three lober. The right lobe ond at the pylorie portion of the stomach. The left lobe terminates at the fundic portion of the stomach. The large epherieal gall bladder, almost equal in sise to the humun gall bludder (one and one-half inohes in diameter). is found attached to the rentral eurface of the right lobe of tho liver. It touchos the margin of the osudate lobe of the 1iver. Bile seeretion by the live is collected by a ceriee of tubules, some of wioh exply into the gall glader. The gall pladdor I. drained by the duotus choledechus or common bile duct. which leads from the gall bladder to the duodenum.

\section{Papcreas}

A light yellowish gland to seon when the cacoum 1. rained; this is the panoreas. Alexander (1915) says the duodenum recelves the duot of the pancress, but the pancreatio duot leading to the duodenum could not be traced.

\section{Selene}

The red triangular apleen is not oonneoted by any ducte to the digentive syoten, but is attached to 
the doreal anterior portion of the 12aun by a highly raseular mesentery, the I1eno-meenteric 11 gament. Although not a digestive organ, the position of the opleen on the jleu makes it wore convenient to inolude It. description here. 


\section{Q132 Rarece}

On the pharyngeal walls of the branchial arehes in polyodon there have developed rowe of gi11 rakera. These g111 rakera evidentiy serve a otrajnere to prevent food from passing out with the respl ratory eurrent. The gija rakere in the -poonbill are espeoially adapted for oeparating the food frow the mud. They are large, brittie, camb-1ike in arrangement, and ourve in an oppoaite direction to the 411 fiJamenta. The rakere arise frow the base of the branchied arches and extend into the phscynx as slender rods in a densely packed layer clese to the branchial gill aroh. They extend into the pharynx for a dietanoe of about one centimeter. There are nine sets of gill rakers. There are 46 gill rakers to an lnch and a rough catimate total about $598 \mathrm{~g} J \mathrm{Jl}$ rakere on one ourface of the p1rat 8131. The gl11 rakere on the anterior aurface are larger posterioriy than are the gill rakers on the posterior aufface of the branchial aroh. but their number is about the same. On the niddre part of the areh the filamente and rakera are jongeot. 
Higure 15 chow the a rrangoment of gill rakers and G131 filawente. Host of the gill rakere average one and a helf inches in length and are curved at the bese, fiving the appearance of a emall riab-hook. The g111 rakers on the more posterier g111s become progreasively reduced in number. The gill rakers on the oventh vieceral arch are more nifom in 120 than in any of the other branehial arohes. They menemred 0.75 inches on typioal epecinen. The following table shows the length of both surfaces of each vieceral aroh at the point where the g112 rakers are attaohed to the reopeotive visceral aroh, and the tosal nuber of glll rakere per visceral areh.

\begin{tabular}{|c|c|c|c|}
\hline 0121 & $\begin{array}{c}\text { Visceral } \\
\text { aroh }\end{array}$ & $\begin{array}{c}\text { Inchee on anterior } \\
\text { and posterior onf- } \\
\text { face of vioceral } \\
\text { aroh }\end{array}$ & 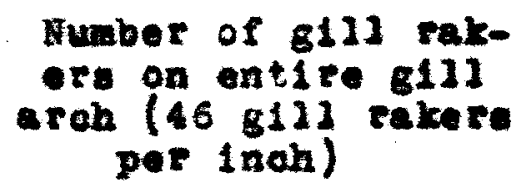 \\
\hline 1. & 3 & 26.0 & 1196 \\
\hline 2 & 4 & 24.6 & 1132 \\
\hline 3 & 5 & 20.4 & 938 \\
\hline 4 & 6 & 18.4 & 846 \\
\hline 5 & 7 & $\begin{array}{l}5.0 \\
\text { meacurement taken } \\
\text { on one bide) }\end{array}$ & 230 \\
\hline
\end{tabular}


Prom the sbore table we see that there are 4342 g111 rekers on four gijia and the eventh visceral arch. In the entire repiratory oystem we would then have 4342 times 2 or a total of 8684 g112 rakers in the epoonbili. This number ohould be considered as only approximate. The very lurge number of gill rakers in Polyodon emphastzes theis funothonal impertance to the flah. They are nore num erous in the epoonbl11 than in other flahes because the spoonbill obtaina 1to food by straining it fros the water by meane of their tremendous number of gl11 rake re.

The laterbranchial eeptu is reduced in eise as in other ganolda. The fllaments are fimly attached to the septum except the distal ends. which project freely about one contimeter. In studying the g111 ot rueturee of lower and higher forms of fighes we find that the more primitive fiaheo poseses the beet dereloped interbranohial septs. In Blanobranche the Interbranchlal septa are well dereloped. In Ganolds they are reduoed. (Polyodon) and in teleosts. which Include alnety peroent of the fishes. there are no Interbeanchial septa present. Hour sete of dendbranche are present in polyodon 
one oet on each of visceral arehes three to elx. There are no demibranche on aroh peven or on the hyoid arch. There is no poeudobranch or falce gill around the opicacle. The oeventh viceral arch is incomplete and extend ae a finger-1ike projection pesteriorly. Further discussion of the visceral arohes 111 bo dealt with under the ekeletal eystem. 


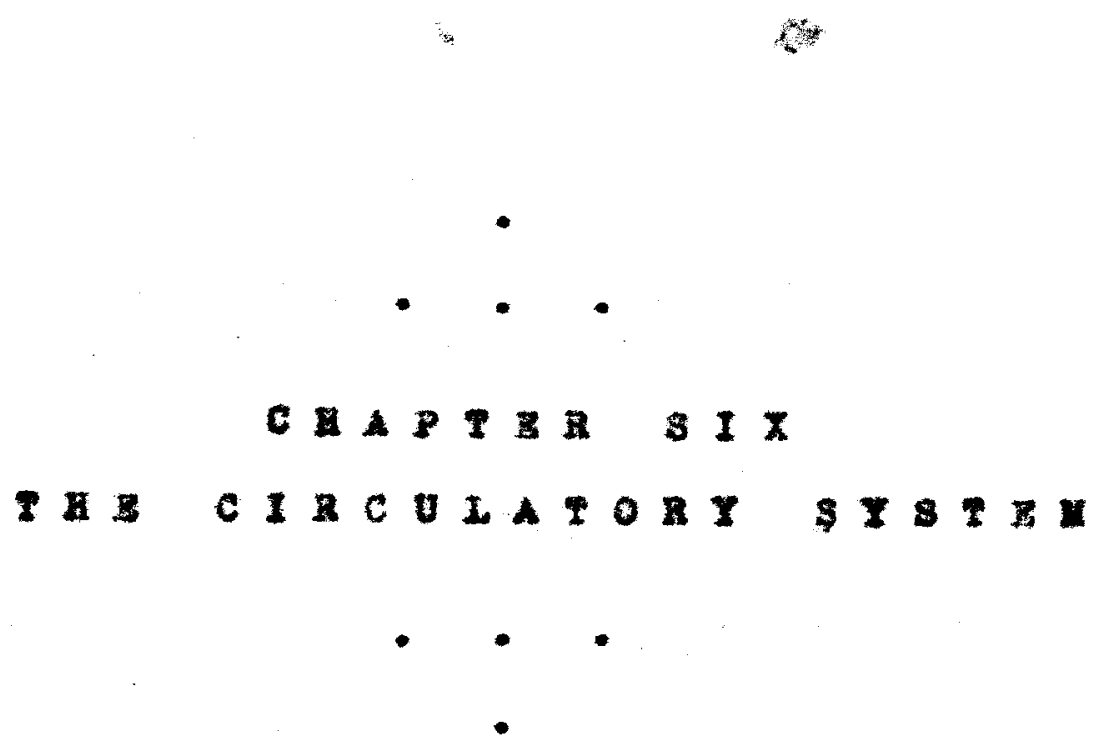




\section{A InJPCrIOA OP BLOOD VBGGLS}

\section{Red kes Injection}

We axed four grane of oandye thoroughly with alght ouble oentlaetere of listilied weter in a worter and addod ooncentrated soditu hydrexide drep by drep unt1 a eranopareat red colof reenlted. Tea grame of knox's gelatine (Inotead of Mrench gelative as (ayer suggeste) was eosked in distilled water until the gelatine was swollen and eoft; then 1t wat remored to poroelaln evaporating-dich and mejted at - temperature of about 19 cogrese C. Whije the geletine was yet ruld we alowy added the coloriag matter, atirring constantiy unt1l a homogeneous afxture was obtalned. Before the wese was allowed to 0001 a 25 pereent acetio aold solution wa added drop by drop. stireing thoroughly unt11 the mase becane 11 ghtly opaque and the odor of amonia

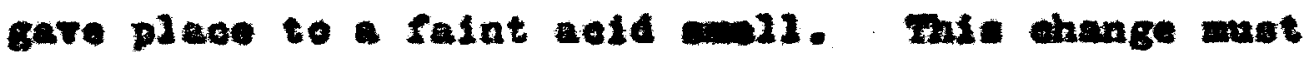
be carefuliy watched, fop tew dropt too much of the sold will spoll the entire mase by preaipltaling the earmine. It the amonia is not completely neutralised, on the other hand, the coloring matter Dild diffues through the walls of the injeoted vessel. 
and etain the enreounding ti waves.

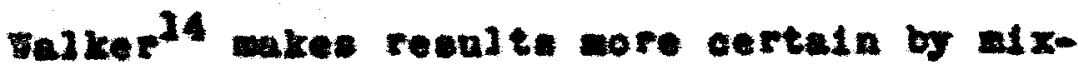
ing one pert of leboratory weter ath rour parte of distilled weter. and then deteralniag the exact amount of the laboratory acetie sold wiah will nentrallzo 1t. Just before using. the mase should be hested and atruined through cloan flennel wrung out of hot water.

Three spoonb111. were injected: one wa 1ajeoted through the beart and the red mes was forced anterioriy through the rentral aete and afforent branehial arterien. Tho eecond injection was through the doreal acte at a polnt where it 11 ee free in the abdeninal carity. This eocond lajeetion wes forced anteriosy into the efferent branohials and ponterioriy inte the distal portion of the sorta. The third injection was through the eavdal artery. The epoonbill Injected through the dorand sorta took the best injeet10n, as wa obeerved during the course of disecotion. The injeotion through the beart and renterl aorta also was euceeseful, but the injeotion through the caudal artery ald not yield sutiafactory reaulta. The mol tod gelatioe 0001 s within the blood veesel foralng a cel which ohowe up very well because it evelle the reesels to thoif ruld extent. 
Bue una integtion

A geletine ras prepared as above. To the vari mas a mfriolent quantity of saturated squeous solution of Berlin blue was aded to give the desired blue color to the relas. This was injeoted into the hepatio portal vein at the point were it entera the I1ver. 


\section{$\mathbf{B}$} THE GQART

The heert of the spoonbill is composed of four chamber: the alnous venosus, auriole, ventriele, and conus arterioeus. The heart does not undergo the differentiation characteristic of the more complex heart of higher animals. The auriole and shus renosue are thin-walled. The auricle recelves the non-oxygenated blood from the sinus venosus and the ventriole sende it forward through the conus arteriosus (19g. 16). The rentriele is relatirely anall in all Bhamobranche, but in Polrodon gathulg it is quite large and thiok-walled. It is more of lese pyramidal-shaped with the bose posterlor1y. two faces directed rentrally, and the other dorsally in position. A section through the ventriole show ito greatly thickened walle. The lining, unlike that of the auricle, 1s rougher and 1rregular. The tendinous cords, chordae tendinae, present in the ventricle of the poonbill are muscular at one end and drawn out into tendons at the other. The enda are attached to the oppocite wall and prevent the rentriele from opreading beyond 1 to oapecty. The base of the ventriele ia joined anterioriy to the conde arteriosus, - short tube. the wall of which is muscular. The three rowe of semi-lunar ralves of the conus bave not yet 
been mentioned. The valves of the anterior row are bett dereloped and eover practically the entire lining of this section of the conus. The valves in the succeding tiers decrease in se the farther they are located posteriorly. The corenary arteries are numerous on the dorsal surface of the ventricle. The auriole (atriua) in the poonbili is thin-waljed and 1a do real to the ventricle. Interneily the auriele is amooth and possesser no tendinous cords which pass across the cavity from one wall to the other as in the rentriele. Communication between auricle and rentricle taken place through the aurieular ventrieular valve, a very smali pooket-like flap. The sinue venosue may be dezoribed as a large delta-shaped collecting sac, the anterior mid-portion of which leads to the auricle, and the base of which is posterior in position. Dorealiy the oinus venosus is fused to the posterior part of the root of the pericardial curity. Connecting the ding venosus with the auricle ie the cino-aurioular aperture, which Is guarded by three stao-aurioular ralves (IIg. 16). These valves are nothing more than folds of endothelial lining of the auricle projecting into the sinus venosus. They are so arranged as to permit the free pasage lnto the surfele, but flow in the opposite difection 1e prevented by their closure. 
The rollowing vesede enter the oinu renoene: Jaterally the posterior cardinal velan wite with the anteriof cardinal veing to form the Duote of curier. which finaly enter the siave renosus. Poetefiorly and oedialiy the large hopatio rein enters tho einus resosus. Tho hepatio reln is the reare of the fusios of the two hopatie reine in theif courec from the liver to the sinus renosus.

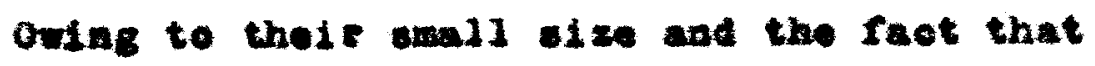
they were not injected, the amall bernobes of the oyeterio relas have not se jet been traced.

The Eenal portal and Esetile Portal Sratem

In Fiches, bealdes the eapiliaries wich unite the outwerd Aletelbutive aysten of blood resbel (arteries) with the Inward colleoting aysten (veins) there are two notable strelnef-ilke complexes of ouplizaries or portal ayotene withie the kidneys and l1yer reopectively. that interrupt the otrean of blood returning to the beart. The roraer is the renul portal system, an additional oapillary complex lavolving the kidneys. The reand portal oystea 1 a device for the return of blope feom the caudal region through a oapillary network in 
the kidnoye. The renal portal ayste joing the eain blood streas aecondapily.

The extre espiliary network of the digentive ayaten comprisee the depatio portal ayetea. The Hopatic portal eyster conalots of a aysted of relne from the opleen, tomeh, 1leus, drodenum, and esecum which enter the liter und there break ap into oapillaries. 7is. 17 bowe pian of el roulation in a fich fafter Walter (2929). 
Herging frov the ventriele to the conus arteriosus. It is not 80 coneplevous externaliy at it 1. In Mamobranchs; but careful study indieated that 1t is about half an inch in length. Whon we cut open the wall of the conus arteritesas, we observed aine eavi-junar valree, three in rov, one close to the other (Y16. 18). These valves appear as 13 rge crescent-obaped pookete. Whioh are waecular ot the base

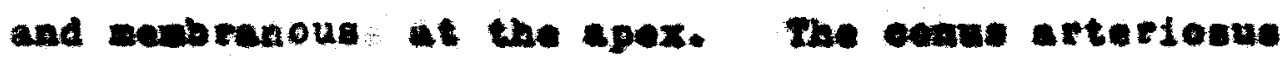
anrrove edighty at lte anterior end and becases tho ventral corta. The rentral gorta 1108 in a deep groore, the groore belng formed in an anterior projecthon of the peeteral ardie. The ventrel corte pasees forward several inches unbrangbed until it reaches the anterior end of the groove. When the ventral aorta wa firot exposed only a eingle palf of affetent branohiu2s at the extrene anteriof end coujd be ceen. This pale of arferent branehlad arteries oupplies blood to the first paif of g113: which are loouted on the third visecral areh (Fik. 29). The esoond pal of afferent branental arterleo loope off 
the rentral sorte doreal and posterter to the firet pale and ean be eeen only by diesecting dorend to the rentral socte. Whis paiv auplice blood to the seoond pais of gilis on the fourth 1 coeral aroh. Srov the dorsal arface and posterier to the second pals of afferent branobial arteries adr of arter1es are given off. one to the left and one to the right. Theee arteries bifaroate on both eldes to become the third and fourth afferent branehisis. The third pair is more antorior: the fourth pas rie doraliy and then pierce the eartilage of the sixth risceral aroh posteriorly. These arteries oupply blood to the third and fourth pairs of gil1s respective1y. which are on the fitth and ixth visoeral arches. The afferent branchial arteriea pas along a canal in the visoeral aroh just internsl to the gij2 filaments. We enali name theoe sanule the afferent branohial oanal .

Irom each of the afferent branchial arteries, wipute arterioles are given off to aupply the gill filaments. The arterioles are too fine to be traced by grose disection. However, during the course of dienection. umall openings were ceen on the afferent branohial erteries. these openings being the polate at wioh the delleate arteriole atruetures were broken. The afferent branchial arteries oarty blood to the 8111 region to be 
oxgenated. The arforent braneblal artertes are of

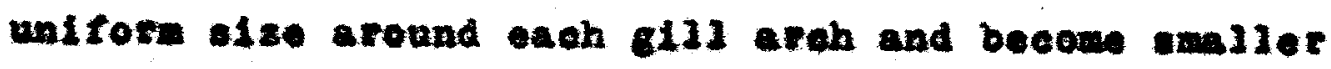
at they reach the region of the pharynx, terminating in the doreal part of the branahiel region.

The eapizlaries to the gill tilewente are connecting links between the arterioles of the afferents with the efferent arterioles leaving the 6131s. The fine otructure of the eapiliary network prevente the tracing of a ingle eapillary by disecetion. The wall of each eapillaty is made up of a oingle jayer of endethellal cells. forming the effective membrane through which the exehange of gaces it ade. 
The doreal aorta is formed by the union of four palre of efferent branchial arteries (Big. 20). They are not so uniform in eize as are the afferent arteries. The firat pair of efferent branchial arterios is a bifureation of the doral aorta. They sre the amaliest of the efferent brunchial arteries. The firot offerent colleeter gives off a branch, the hyoldean efferent artery. This artery is woualiy called the common or pesterior carotid artery. ${ }^{25}$. It goes to supply blood to the head and spiracle reglon. The other branch to either side. which is a continuation of the firot efferent branchial artery, oupplies the first pair of gill arches. The second pair joins the doras aorta imediately posterior to the firat pair and eupplies the second pair of gIJl $^{\prime}$ arohes. The thied pait is quite large, looping off the dorsal aorta and ourving back in a v-abapod manner to supply the third pait of gill arches. The tourth pair of efferent branohial arteries also loop off the dorsal aorta and are quite large. The fourth pair of efferent branchial arteries bifureate to ither alde to fom the amall pre-trematio branch that supplies the fourth gill arch and goes to the third gill alit, and larger poot- 
trumatio branch thet supplies the fourth gi13 aroh and soes to the rourth el1 exit.

The derand aorte it opmpoed of a bot anterLor palrod pert and long pooterlor unpal red portion. Mo palred portion gives rive to the brolden arterles: the unpalrod port reocives the oeopd. third. and fouth pal re of efferent branchial ateries. The

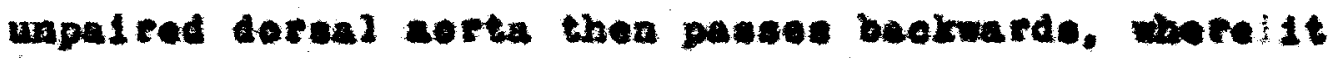

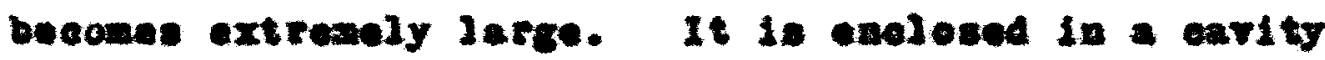

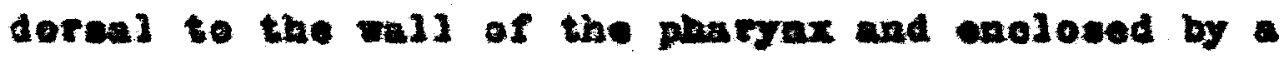
taick nombren, a pertion of the picletal peritenem.

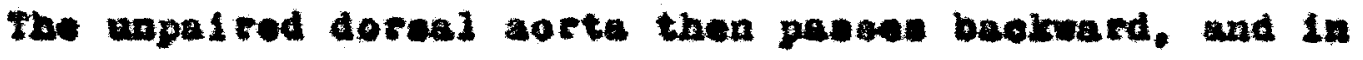
1to eoures through the body given off arteries to the digertive tract and Ite appondeger, to the extrent ties. and to the body muevileture and doeper etractures.

Arter leving the eanal in the 411 regton, the

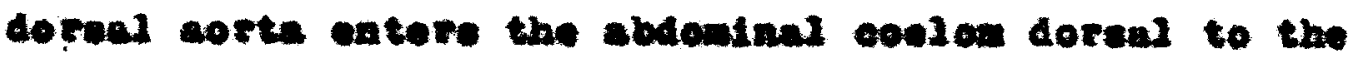

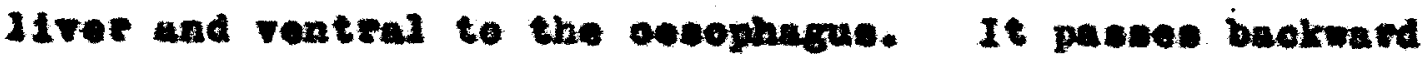

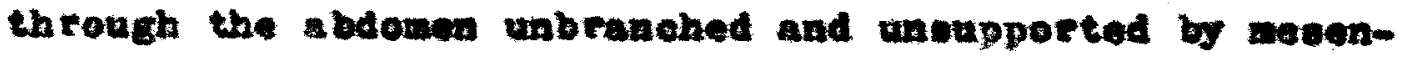

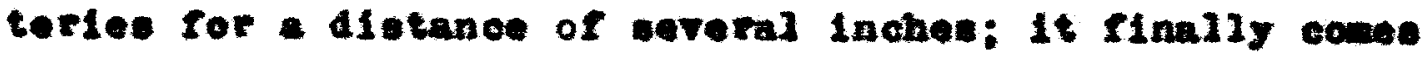
th the regton of the vedian lobe of the 117er where it Ile adjeont to the portal veln. The dored corti now given off bhort. broad artery. the getro-bepetio artery. The arterial aupply to the algetive trate it rery oomplianted at this point. The hort cuotromepat-

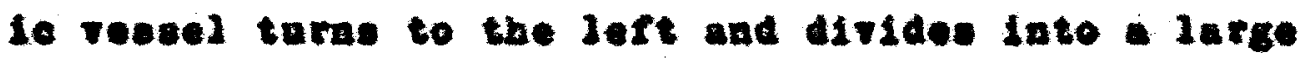


hopetic artery which goes to the dorsal ourface of

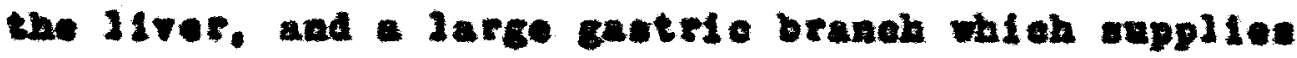
the anterior and poterlos deran surface of the stomach. The hopatie ertery aivides into owalier bepatioe and fladily late eaplilaries athin the 1iver. The gestric artery dividee inte analler gantio branches and finelly into eapillaries on the wall of the stomach. It the point where the gastrohopatic learee the dorsal soste, but to the right, the doreel werte gives oft two srteries; one to the ventral aurfece of the oesophagre. the conophegeal urtery. wid the other the gatro-duodenal artery. whiah bifuractes to rorn a gusteie braneh to the ventrel cardias portion of the etomoh, and a branch to the duodenum, the duodenal artery. (The large pylorie eaceun to very raseulat. This etructure Indioutes that the eacow is runctional during 1ife.)

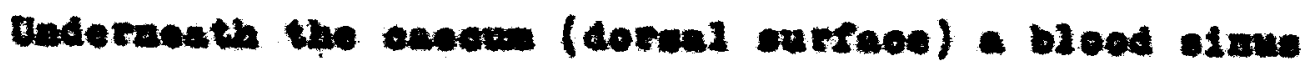
10 prenent. From this reseviar otraoture on the

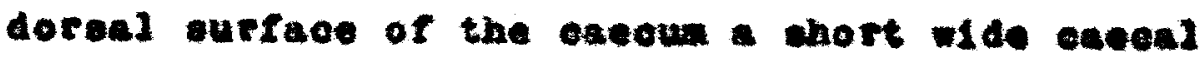
artery is aiven off to the eaceum. The caecal artery divides Into about fire moderately larce ouecal branches aleo supplyfing blood to the cuncum. The dorad corta contlaues poaterlorly over the spleen enelosed in a thlek fibrous cheath. This portion of the worta is the oplenie artery. It pasces orer the apleon and gives 


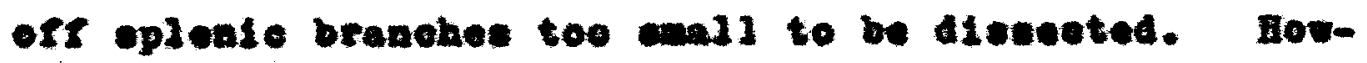
wer. by ralolag the artery at this point. It will break off from the opleen. to whoh waler brenches pare.

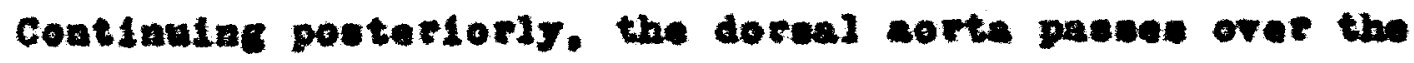

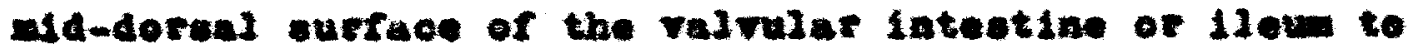
beeone the posterier dorad intertinal artery. Smailef arteries terminate at whe reetum; these are restal arter1ed. Irow the doreal enrface of the liev the postertor intestinal ertery alves off about nine ond arteries to the Idnere of wesonephroi: these are the remal arteries. 


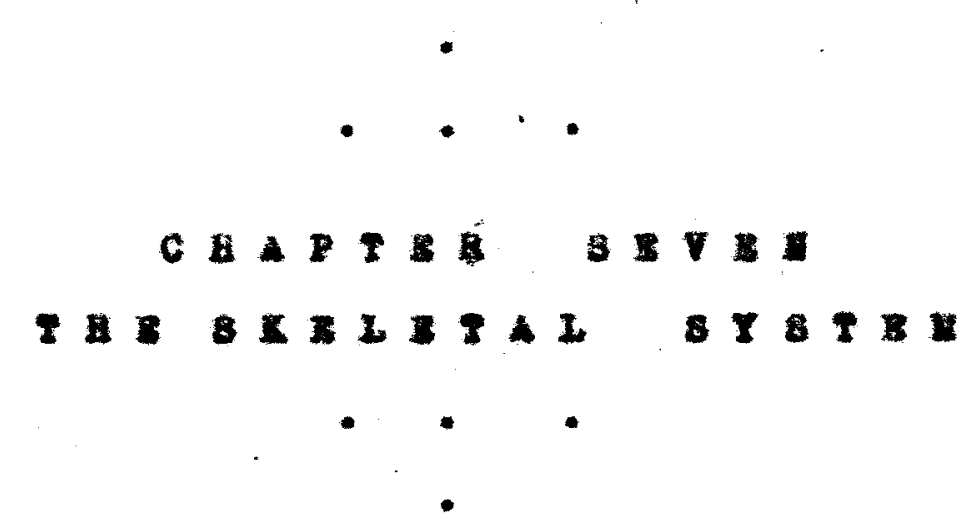




\section{IUTRODUCRIOA}

walter (2029) divides the ganolde into two clesses on the beote of okeletal derelopment. The firet and wore prinitive elane ecmprisos the cartilagizous ganolde, which lnelude the paddiefish, Poljodon of the Bulted states; Peophurue of Onina; the eturgeone. Aelpencer and Beaphichrochus; and the car-pike lepldese-teus. These are ealled eartilaginous ganolde becalue theif greletons are partly ourtilage and partly bone, and show a traneltion betweon ginamobrunche and bony fiches. The otber ourviving elaps ineludes the bony ganoids, so celled becauen the ofetllaginous componente of the axeletion hire been quite completely replyeed by bone. The bour ganolde inelude the Polypterus, Callimelentbye of Afriee, and the bowrin, Amia, found in rivera and Iakes of the Dat ted States.

The endonkeleton 10 brieny deecribed by Kingeleg (1925). "Tho endonkeloton is outlined in captilace. but nobrane bones may be added to the prialtive framework, eopeetediy in the hoede of the higher groupe. In

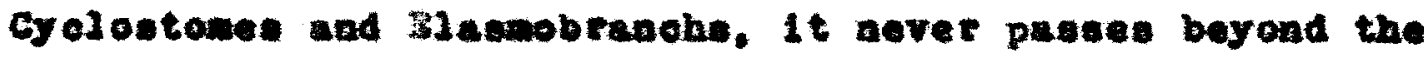
eartilage stage, but in all other groups wore or loue of the oartilage is converted into bone, the amount of this 1ncrearag, the bigher the animal in the soale. To the cartilage bone thus formed, abmbane bones are added. 


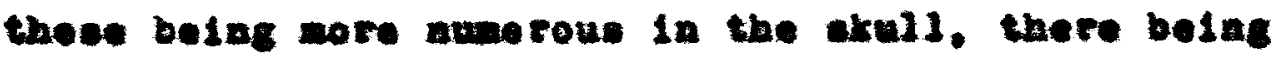
aone in the rertebral colung of the and for in the eppeadieular okeleton."

Staoe Folyedop It a entilaginou ganold. and the ranold fiche ate the next higher group of finhes oret the manobrabohe. we chould expeet to liad only

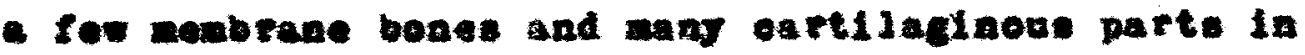
the elejeten of palyoden. 


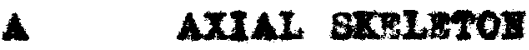

The axial wkeleton inoludes the franowork of head, trunk and tall (notochord in polyoden and lower vertebrates).

\section{Tha Craniun}

The ekull of Polyodon epathula is composed of a relatively thin-walled craniun or brain oae, a series of cartllaginous rigceral arches and capoules for the cygane of epeolal sense. Figure 21 chowe lere elde Tew of the irull. jawe, and peatoral girdie and Inner Tlew of the right jaw in poljodon. The eranium is dorco-ventraliy depresed with the long cartilaginous rosetrum protruding anteriorly into the opathule. At the most poetero-lateral portion of the roetrua are found the olfactory oapale for the racal apparatus. The eaptilegee of the capsule are exceedingly thin-walled and open to the exter1or by way of the nagal apertures. The nasal capsules fuse with the cranium. In the nasal fosea are found the Ianellae. These are Ifteen lanaliae in ench nagal fosaa, arranged in radial facton, otarting from a point on the dorso-modial wall of the fosat. ME. 22 howe the arrangement of lamellae in the fosea. These

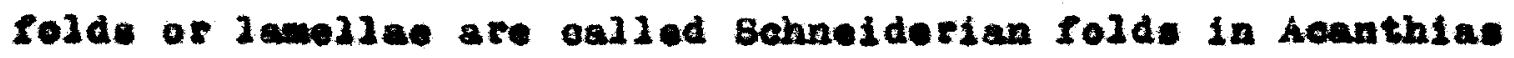


aceording to Dende) (1928). The folde produce acceseory folde in which are found the olfaotory senve cells. The optic capoule does not ruae th the craniue. On each alde st the posterior third of the cranium is the auditory aperture or opiraole in which the organe of besing are looated. Between the audItory and nams capaule is th comparstively onall ellipitical-shaped opt10 fosar for the eye. Overhansing the foss is the supra-orbital crest. the antertor projection of which is the pre-orbital and the posterior one the post-orbital procesa. The rentral portion of the orbit bends downwerd forming the basal angle of the orbit. Anterior to the based angle and extending from the refia of the erantua is a projection which is the anorbital procesa, wioh Allia (2023) oalls the ectethmoldal procese in the dogfiah. 16 The wall of the orbit is composed mainly of thin cartilage, except the portion medial to the orbital procese, whioh is compoed of a thick-walled cartilage.

ILgure 24 how a doral view of the skull of polyedon apathule, Note that the ontire dorsal surface 1. dermal in eomposition, except for a asll part, the chondocranlum. Jocated between the antexior fontonelle and the foses. The opathula measured approximately 16 om. in length, whereas the region from the anterior 16.111. as quoted by Danielo (1928), p. 42. 
portion of the olfactory focen to the posterior end of the pterotic measured 8.5 on. This estieate howe the proportionate length of the onout with the remalnder of the slull. The dermal osoleles are numerous on the unout. The cartilaginoue rostrum is wident posterioriy and narrow anterioriy within and in the center of the epsthula. The olfaetory capsules are latero-ventralig located, just anterior to the orbits. but way be partikily seen in dorsal view. The portion of bone between the optic foseas is the frontal. The region posterior to the optio forcas to the point where it fuees with the pteretie, is the parietal bone. Sutures are laoking in polyodon henes abuep distinetion between the ifferent bones in diffioult to make. The hyomandibular can be pirtialiy eeen in dorsal viow attached to the mid-rentral portion of the oranlum. The widest part of the crantum, the parietal, messured $4.4 \mathrm{om} . ;$ the widest portion of the snout measured 4.2 on. Attached to the posterior part of the pterotio 18 the poet-temporal bone, which is long and thin and Inclines at an angle in a postero-lateral position. The poat-temporal ie attaohed to the pectoral girdle at its posterior end and is sometimes conaidered a part of the glrdie. 


\section{Handrbular and Hrald Arebes:}

The viceral ukeleton is composed of a geries of cartilaginous arches whioh eurround the pharyax. The arches may be divided into two groups: the mandibular and hyold arohes, and the five pairs of brandmal arohes. whloh support the sill filaente. The mandibular or firet aroh, upon which the tepth are borae in the young speombili, hes become nost highly epeolalized of all the vieceral arohes.

The component of the upper and lower jaw of the -poontill ake Polyodon an interesting speoles for anatomioel etudy from the eroletiosary otandpoint. In the dogfiah the lower faw consiste of a single piece of cartilage Heckel's and the upper ja also of a eingle piece of cartilage pterygo-quadrate. This is redueed In Polyodon and modified between two portione of dermal bone: externaliy Heokel's oartilage is covered by the dentary. and internally by the splenial bone. Heckel's cattilage is best developed posterlorly. The pterygoquadrate cartijage of the upper jav is modified in a similar manner by belng partialiy covered externaliy by the maxillary, and internaliy by the palatine bone.

The wandibular aroh 1s attached to the cranim through the hyowandibular. This is known as the hyosty21e type of attachment. The hyomandibular is broad and 
flat anterioriy and eurves to beoone lese broad and flat posteriorjy. Anterforly the hyomandibulap is attached to the nid-ventral third of the oranium and posteriorly it connect to the aymplectio oartijage. The aymplectic is a boot-shaped plece of ostilage to which pany parts of the skull hinge. It is Interesting to mention that the oympleotios are found only in Teloosta and two ganolds. Adpeneer and Spatu1arla. The symplaotios appear distal to the hyoids. as a part of the hyoid aroh.

Fig. 23 ahow the attahmente to the symplectio oartilage. The postero-ventral aurface of the hyomandbular hinges to the doraal aurface of the aympleotic. the stylohyal to the pooterior surface, und the mexiliary and bieckel's cartilage to the antero-ventral surface of the aymplectio cartilage reapeotively. The cerato-hyal end posteriorly in a knob-akaped otructure which is the -tylohyal cartilage, and medialiy us the hypohyal oart11age. In Rolyodon gathula the otyd ohyal appear a a partial fusion to the ceratohyal. I7 The eub-operoular is attached to the postero-lateral surface of the atyzohyal. Antero-doraliy the gymplectio is bound by $11 \mathrm{ga}-$ ments. the quadro-symplectio tendons. to the pterygoquadrate cartilage.

17This atructure is not aamed by Traqual in Figure 21 and appears as a seperate structure. 
osesfiation centers are found in the epoonb111; as for example in the hyonandibular and oefatohyal cartilagea. This is algnificant in that it showe the tranultional atsge polyoden holds between the Glatwobranche and the Teleoste. An additional polat of interest in thi direction lo that the doreal pertion of the akull of Polyodon in almost antirely covered wh thin plates of temal bene derited from ganold soeles.

Eranehis Arohe:

The brenehiel arches conolat of $a$ number or segonate. The firot branchial areh way be tuken as a type. It has fite segnents. The ficat pule of branchied arobes arise from the postarior portion of the bueoul carity juat medial and posterior to the

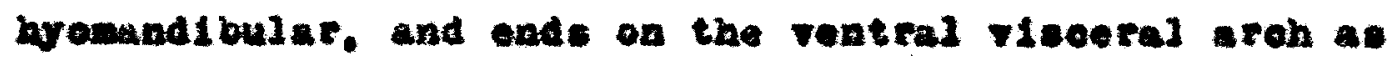
the ball-branobial cartilage. The sooond, third, and rourth branchial arohe are aladlar in otructure to the firgt betsolhtel areh. A typlosi brenchlal aroh (Fig. 25) chowe two large cartiligginous eegments oonotituting the gratar portion of the aroh, the doraal segment; the eplbranchitul, and the ventral segment. the cerato-branohid. Thece two segunts sttach lateraliy by aepte of connective tiene. Yedinjly 
and atteahed to the eplbranehial eartilage It the anall pharyago-branohlal cart1lage. Hodially and ventrally attaohed to the ceratobranehial, is the awall hypobranohial cartilage. Medial to the hypobranchlal is the basibranchial eartilage.

In Polyodon the g111 rakere are onltinous. Their number and atructure have been discussed under digeotive and respiratory oyetona.

F1g. 26 mows the upper side of the rentzal vlaoeral srobeg in a typical 90 on. apeolmen.

There are throe basibranohial cart1lages. The firot baslbranohial fuees with the basthyal and measured 2.5 en.. the second $2.8 \mathrm{em}$. the third 2.8 or. In length. A pair of basihyal oartilages fuse anteriorly to the pid-ventral portion of the first banibranchial cartilage. Lateral to the basihyals, the hypohyad cartilage are attached to efther oide. To the first basibranchial are attsolued the first three paire of hyobranchiel cartilages. The fourth pait of hypobranchial s fuse ard sttach ventral to the cecond bestbranchial. The f1rst four palrs of ceratobranchlal are attached to the reepective pairs of hypobranchiale. The fifth ceratobranchial is attaohed to the third basibranchial cartilage. The fifth rudimentary brantihial aroh it suced to the fourth to: 
branohial aroh posteriorly and beara only gill rakare. all the branohial archer are approximately the eamo length.

Since the skull of Polyodon is composed of two dietinct parte, the cartilaginous ohondrooranium and the oreriylng dermal plates, we mall liot these etmoture separataly. The following table shows the dermal and cartilaginous portions of the skull. 18

Dermel Parte of shuld

1. pterot10

2. Post-teaporal

3. Parietaj

4. Frontal

5. Paracphenoid

6. Tax 111 asy

7. Palatine
Cartileninops Parts of Skul2

1. Rontrum

2. Chond roc ranium

3. Pterygoquadrate (palatoquadrate)

4. Heckel'. cartilage

5. Hyold $8 \mathrm{rch}$

a. Hyomand I bul ar

b. Sympleot $1 \mathrm{c}$

c. Ceratohyal

d. Fypohyal

e. Stylohyal

6. Branohial arches

a. Pbaryngo-branchlad

b. Eplbeanohial

c. Caratobranchial

d. Hypobranchial

- Basibranehial

7. Cspoutes of organs or opecial sense

a. Olfaetory capoule

b. Optic capaule

- otio capeule

\section{Dentary}

18 In this use of the word skull the author follows Kingeley (1926) who includes the cranine, oapoules of organs of opeelai sense, and the viecerel ukeleton under this 
Lermal Parte of tral1

cert1leainoue Rarti of Grall

- Bpleniaj

10. oesteles of enout

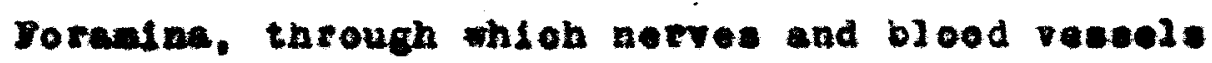
pase perforate the oranius. On nakias s englteal cootion through the head and opathale we round that the rostrum containe fat-1ike aterial. The brain is andi and prialtite and ourrounded by thide mases of ourtiage and dermel bone. The bone is external to the cuctilege enoasing the brain.

\section{Lertebrel colum}

The vertebral colum in golyodon epathula, because of 1to elmplicity. ia espeolaliy intereating. It consiste of a long central colum which is oventialy the enlarged aheath of the notochord, or notochordal cheath, and the jel1y-11re abstanes, the notochord. whin the besth. anterioriy the centeal columan is continuous wth the oecipital ragion of the eranium. at with polat the colume becones lareer and firmer wherane poeteriorly it 1 o obeerred to extend to the doreal Jobe of the oavial fla. Aoeording to Ferbes and Al ahardeon (1909) the rertebree are 1mperreetly formed and the antertor pertebre are singlo. 
4y invertgatione confim thet atutement. kbore the central eolum there 18 a cerles of noural arohes, bet dereloped in the trunk rogion. Jees developed in the caudal regiob. Thare are both noural and haend arohes in the esudal region. The ajural arohes proteot the epinal cord, the hasmal arohes protect the ceudel blood reabel: In the trunk reglon the doros ckeletegenons eeptum it bet derejoped and IImiy attuched to the vertebral ooluman. A lateral plew of the rertebral colum in the aid-trunx region is aboma in $1 \mathrm{~g}$. 27. the sort notochord in very printtre, and only partialiy surrounded by aeentroue rertebrae conaleting of epparate arcual12. Eate that the doral and rentral surfaces of the notockord are covered by cartilaginoug aroualia. whereas the Iaterul surfeces are exposed. on the dereal curface are the 1 arge bagloreals, united frow either side to form a aural aroh continued by a neural apiae. between the bagee of the baeldorenls are the amall thangular interdoreal. The ventro-lateral regione of the notoohord are covered on each sla by the babirentrale frow which a velichal rib projects. The basiventrel do not weet below the notochore. Betreen the baelventrale are the owall interventrals. In tric ouudal region the neural arches ere lenat dereloped and the haead arohes are most ancked, wo the region of the ful ore. The haenal arches protect the oaudal artery and 
yein; hance we oan account for the greatest derelopsent of the hsemal arches in this reglon. The central colum is best devejoped in the trunk region. Dorael to the central colum and to either ide aro the neural plates that fuse dorsally and make up the neural apines. These cartilaginous plates are nore or less rectangular in shape at the anterior and trunk regions of the colvmn, and triangular in shape in the caudal region of the column. The neural plates have thet beee on the notochordal aheath. The neural spines are large and projest in a doreo-posterlor direotion. The neural sines, noural arches. and central columen are covered by the axial memirane from the head to the tip of the tall region. Fiftyelght neural arches are present on the notochordal sheath. The neuraj plates are perforated oy the roote of the spinal nerve. This ia more olearly shown in the anterior and trunk rogions. The rentral foramina are not clearly show in dissection, howevar Kingeley (1926) atates that they appear during vertebral developrent of polyodon.

with reforence to Chondrostel in general, wy investigstions show that the notochord in living form ia quite uncanstrioted, and murounded by a very thick sheath outside wich are no true oentra. Only pleural 
ribs oceur is Jiviag chondrostet, but they are unknown in extlect fanilies. Doresl sibs are sbeent. In gelrodoe apathula the ribo are of the pleurml type, but reatigisi.

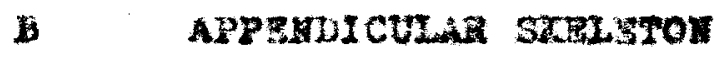

The appendiculat akeleton in the framework for the girdies and fins, the latter being attached to the edrdies.

Sreleton of the falced Ine

16. 28 showe a lateral viev of the pectoral gledie. The pectoral glrdie of the poonblil in compliested by the uddition of wembrane bones to the curtilige bones. Suab wabrane bones are homologout with the dermal plater of the exockeleton. The derwal portions of polyodon conist of the elaviele, cleithrux, and postelavielo wheres the cartilaginous portions consiet of the ooracold and scapular region. The branohial artery and nerve pase through the seapalar corusen to supply the fin. The pout-temporal bone as prevloualy otated may be lneluded as a dermal portion of the pectoral girdle. serving we bone attaohnent between the alrdie and the kkull. The homologies of the pectoral fidle of solyodion and ether chandrostel bave been diseuesed by Hower (1924). 
115. 29 ehow the medial view of part of the peoterel girdie with peotoral fin stechanat. The pectoral rin is fen-shaped, the proxinal portion of whloh consiste of fout baed pleces of cartilage. The firet two pleces (anterior) of basal eartilages fuse of they touch the surface of the girdle. This portion of eartilage to allled the proptergatun. The third olagle plece posterior to the propteryglum is the weopterygin. The rourth siggle and wajleat plece of eartilage is posteriof to the mesopteryglum and in culled the metepterygtun. Several redial are found between the propterygion and moepterygl and tues with thes. The derael portion of the peotoral Iin hows radial arrangenent (dermotrichle) but not co anked as in the post-doreal, caudal or anal fine.

\section{Relvis Girdis and Els}

The fraberork of the pelple givale and fla con- lote of a thin segmented cartilaginoue plate, (8 pleces), the basipterygiun, and 11 cartilaginous radisle which sre reatral to the basipteryglum. These radials are ungegrented and extend in postere-ventrel direetion The derwal portion of the pelfio fins le elailur in etruoture and arrangement to the pectoral rine. 
Ekeleton of the Inpelred Ing: The posterior

\section{Deresi nin}

The certilaginous radiale of the dorat In are thin and not well mariced. They are unsegmented. The deras portion consiets of radials that extend In a postero-doras di rection. Riohardson (2909) ays there are ficty to alxty-five dormal ray present. Wy estimation showed forty to fifty doroaj rays present in three spentmens.

Gaudal yin

The cartilaginous radials of the caudal fin are prolongations of the haemal splnes of the haemal arches. The radiala extend in a posterior direotion and continue bacicward ag the dermal fin rays. Whioh extend in a posterior direction.

Anal In

The curtilaginoug radial in the anal fin are more marked than in any of the other fins. They are largest anterlorly and becone maller posteriorly. There are two rows of radial the diatal row, an in the pelvic girdie, are the better developed. There are elghteon diatal radialo in the anal fin. Tha dermal portion consista of dermotriohia. The dermo- 
trichis extend in a postero-reatral direction. Aeeording to Porbes and Alchardicon (1909), about elxty anal rays are present. This number io approximately correct.

\section{me palox}

Just anterior to the doresl 20 be of the oudal rib are laree spinee (modified soalea) ealled fulera. They consist of the hardent material that cen be found in the opoonbill. The fulore are considered a part of the exoskeleton since they arise as direct oafificatione in the oorium, no artilage appeuring in theis derelopanat. (KIngeley 1925 ). 


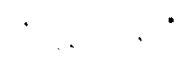

$\bullet$

O I I IIAL

COITIE II I I

. 


\section{Sumary of Original Contributiono}

In dienecting the lateguest. branched canal. paselng out rron the lateral line eanal were obeerved (FIg. 9). Histologlcal seotions of lategument chored veriations in pigmentation due to the differences in -1ze, hape, and amount of chromatophore present.

The large evis bladder wa tound to be perwanently conneoted with the oesophague by a pnounatic duet. thue placing the opoonbill in the Physontowous group of fiakes. From 1 te poor blood supply the owi bladder is not conaldered to have moh respl retory function in polyodon.

Irom the presence of partly digented food in the pylerio oseow and lte rieh blood supply. It is beliered that thi organ takes an active part in digestion in the apoonb1l1. The jiver was found to have a very large spherical gell bladder one and one-halt Inohos in dianeter.

There were found to be aine sete of gill rakers on each side of the pharynx. paok set except the most posterior one contalned about 500 individual rakere. and the enti re respiratory aystea was found to contain approximately 8684 all rakers. Tho epiraole was dorold of pseudobranch or ralae glj1.

Three rowe of conilinas valves vere caund in the oonus arterloew of which the nore posterier are 
best develeped. The olno-eurieular oponing was found to be guarded by a set of three valves. The wulle of the ventriole were found to have ridges, the corda tondinae. Tho rentral aorta gives rise to three palrs of afferent arteries, the third pals again bifuroating to produce a total of rour paire of arter10s thich supply blood to gill arohen one to four reapeotivelj. The doreal aorte in forsed by the unloa of four palfe of efforont branchial artaries. The reanrkable condition of the doreal aorta whioh 11es froe In the adoninal coelon, wanpported by mesenteries. for a distanee of ceveral inobes, is an uneound reature.

The attrobuent of the upper jaw to the exanium 18 of the byostylle typo, that is by mase of the hyold eroh.

Thore is a ayaplectle ourtilage on the mandtbular arch, a eartllage whioh has been reported in only two geners of gruolds. osulfiention oentere were found in the hyomandibular and ceratohyal oartiInges. Woakel' curtilage is surrounded externally by the dentery bose. and internaliy by the oplenial bene. The ptarygo-quadrate onct1lage of the upper Jall le likewl se oureounded by bone. externaliy by the maxidlary and laternally by the palatine bone. The abore pointe indioate the traastionul stage polyodon 
belde betwen 31 aneobrachs and Teleosts.

The doreal ourfuce and the ventral ourface of the okuld is covered vith demal plates of bone except for a wall part were the obondroctenilua is expoeed (15. 24$)$.

It wan found that the basibyal and firot basibranchial fase, and that the fourth hypobranchials fuse together renterd to the eceond and thled besibranahiala.

The ourtilaginous branchlind arohes are segeented. Deresily the arch conelete of a Jarge opibranchlal and amall pharyago-branahial oprtilage; veatealiy of a long ocratobranohial and two amall cartilages: the hypobranchial and wedialiy the bantbranchlal eartilage.

The rertebral coluan is peinitive, aoentrous, and consiating of sepsete areualie surrounding the notochord. The notochord is not constrioted by antra. Vestlgial ribs project from the balitentrale. small interdersajs are found between the basen of the large buajdoralle and mall interrentrale are present between the bualreatrala. The peoteral girde conelste of mexbrane bones and oartilage bones, howing a further evolutionery 
olgaifloanoe In polyodon as a linkigg genus betwean Eleamobranohe and Teleoota. The mombrane bones are the poet-temporal, pout-clariele, clariele and oleithcun; the cartijagenous portlone of the girdle conelet of the fuesd soapule and correold certilages. 


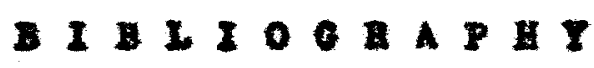




\section{BLLlocrapax}

Ho olatim is ade that the bibliography of this report is a couplete revune of all published literature in this field of rewesch. I belleve, however, that it does include the more important referenoes on the oubject. Very 11ttie information, a far as wo know, oould be obtained in reference to the anatony of the apoosbill.

Adame, L. A.. 1033. Introduction to the Yertebrates. John viley and Sons, Ino. Hew Tork. p. 64 .

Alexander, H. L., 1016. Hore Abont the Paddlefioh, Folzodon and thala. Traneactions of the Ameriean Vishertes Bodiety. To1. XLV (no. 1). pp. 34-39.

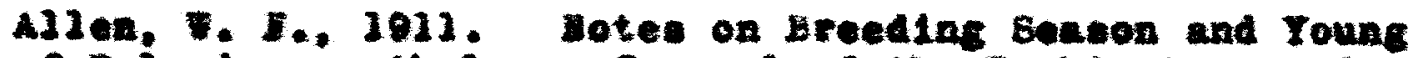

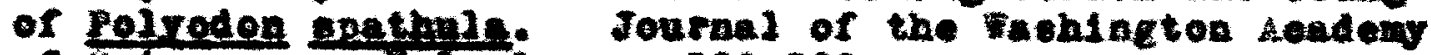
of sel enees. ToI. 1, pp. 280-282.

Ameriean sneyclopedia, The 1879. Sdited by atpley and bene. D. Appletod ce.. Tew York. Yol. VII. pp. 277. 614.

Comn, A. A., 2026. The Splay Doerish. The Heanlilan Ce.. Wet Iork, pp. 5-35. 


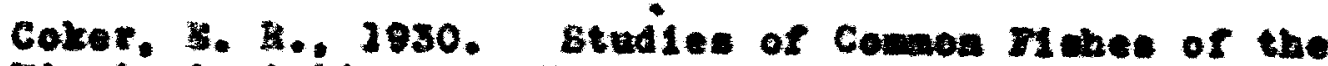
Hiest ent ppl giver at reokuk. b. s. Dept. of comeree. Dureau of yishories. Vol. Vh, pp. 141-140.

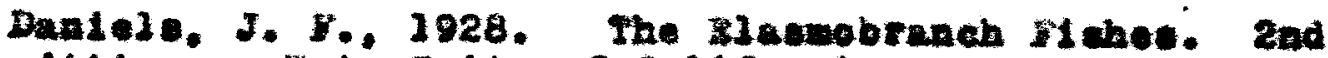

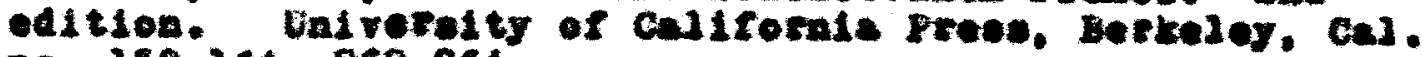
pp. $358-264,262+264$.

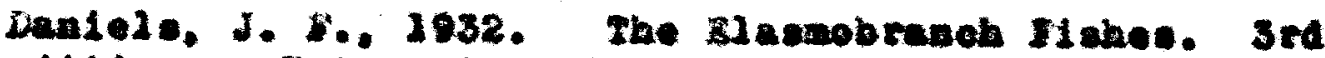
edition. Cniveralty of Celiforais Preen, Borkeley, Cel. pp. 41-50, 161-166, 264-265.

Baey ol opedia Americane. Tho, 1932. American Corporation. Lth odition. Vol. XII. p. 277.

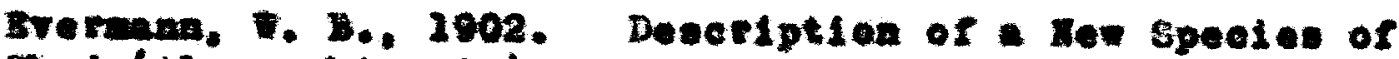
Ebad (Alose ghingle) with notes on other Food Pl shes of

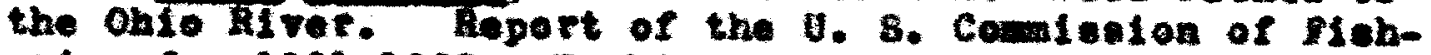
eries for 1901-1902. Washington, D. C. Pp. 273-288.

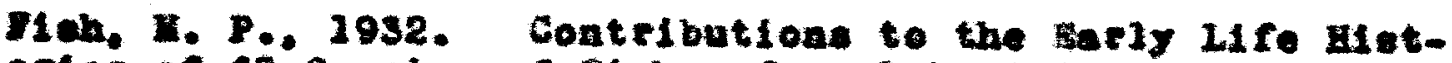

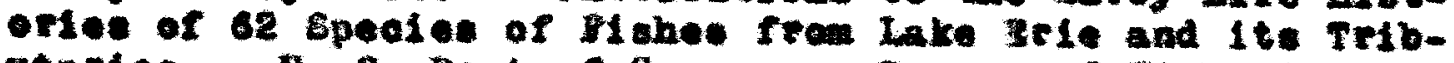
utarles. b. S. Dept of Comaree. Barean of Fioherles. V01. XIVIII. p. 306.

Yorbes, S. H. and Al ebardeon, A. A.. 1909. The Ilaher of the Lilinole fatural hletory surray of IIIInole. Vol. III. Iehthyology, pp. $35-20$.

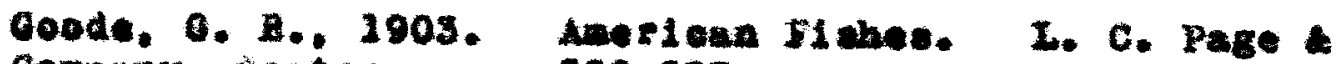
Campuny. Boston. pp. 630-533.

Geodrioh, R. S., 2930 . Studies on the strueture and Developene of Vertebrates. Hacailian and Co.. Wer York. p. 404 . 
Cowsalach, I. J., 1933. Fishos and Plahing in Loulelana. State of Louleiant. bept. of Coseervation, Ion orleans, La. Bul1. XXI11, p. 374.

Guyer, 1. I.. 1932. andwal Hiorelogy. Onlvereley of

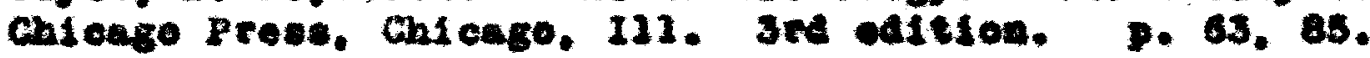

Hegner, R. W.. 3029. College Z0010gy. 3rd edition. The Deantijan Co.. Gor York. p. 409.

H12debrand. 7. S.. 1930. Cold Blooded Vertebretes. Fert 1. Fiches.' Smithsonian belentifle Beries. Vej. VIII, pp. 22, 23, 34-36, 60-62.

Huseraker, Loute, 3012. The Spoonb111 Hebery of the

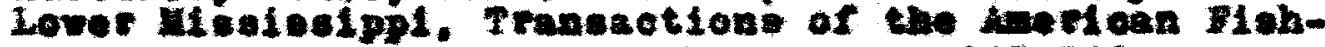
eri ea Boolety. Wainingtoa, D. C. pp. 34b-246.

Hyan, L. H.. 1028. A Liboratory lanual for Comparative vertebrate innatow. University of Chioago Prese. Chleage, 111. pp. 21, 61, 63, 87.

Jordan, D. 5.. 2907. Diskes. Eenty Hole \& Co., Hew rork. pp. 256, 257.

Jorden, D. S., 3945. M1 bhes. Appleton E. Co. Fen York.

Kingelay, 8. I., 1925. The Vertebrete skeleton. P. Ble-

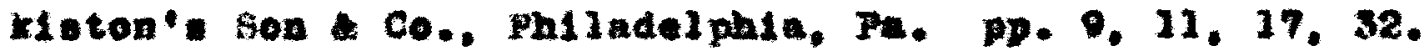

Hagel ey. 3. J.. 1926. Conparative Anatony of the Vert-brates. P. Blakieton's Son * Co.. PhLladelphia, Pa. pp. 32, 44, 86, 126, 248, 267. 


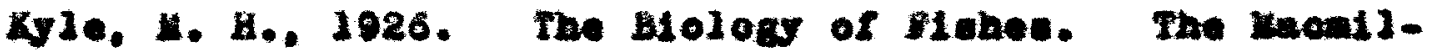
Ian Co.. He: York. p. 267.

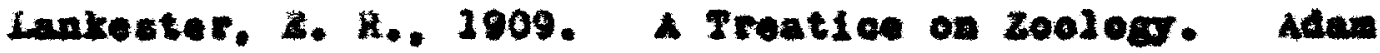
and Charlos Black, London. pp. 308-321.

Parter, J. T., and Hacwe12, T. A., 1928. 4tb odftion. A Textbook of zoology, Menilian and Co.. Ltd., Londoa. DP. 218, 221. 236.

Pratt, H. 8., 1005. A Couree in Vertebrate Zoology. G1an and Co.. Hew York. pp. 2. 4, 34.

Riohardeon, 8. A.. 1913. Observations on the Breeding Hablte of Fiehes at Havana, III. 1910 and 1911 IbId. vo1. 1X, 1913. Erbana, 13i. pp. 408-416.

Hower. A. 8., 1024. Pootorel Limb Hugouleture and thoujder girdie struoture in $1 \mathrm{ch}$ and Tetrepode: The Aantoniond Aleeord. Vol. EXVII. pp. 121-130.

Sette, O. 8.. 2025. Micherien Indueteies of the U. 3.

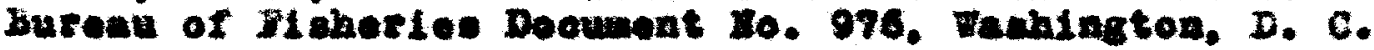
p. 219.

Bteokard, 2. C., 1907. The Obsorrations on the Matural Hietory of Pojrodon gathule. Amorican Hsturalist. ves. xil. pp. 753-766.

Thoupsen, E. D.. 1033. The Tinding of Vory Young Polyodon. Fron Cepela. A Jourael of Cold slooded Vertebrates. Fubliobed by Anerioan Boclety of Iohthrologiets and Berpeteloglete. 702. 1. Dp. 31-33. 


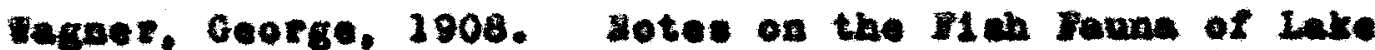

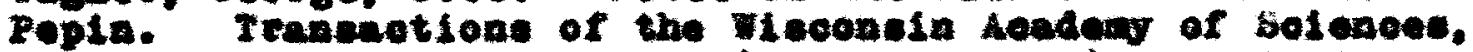
Afte and Letere. Vol. XVI (Port 1. Ho. 1). Dp. 23-37.

Nulter. A. A. 1029. alolecy of the Vertebrates. The Hacilian Company, Hew Yort. pp. 28, 65, 215, 273-275. 371. 502. 
ILIU STA A T 1 O 


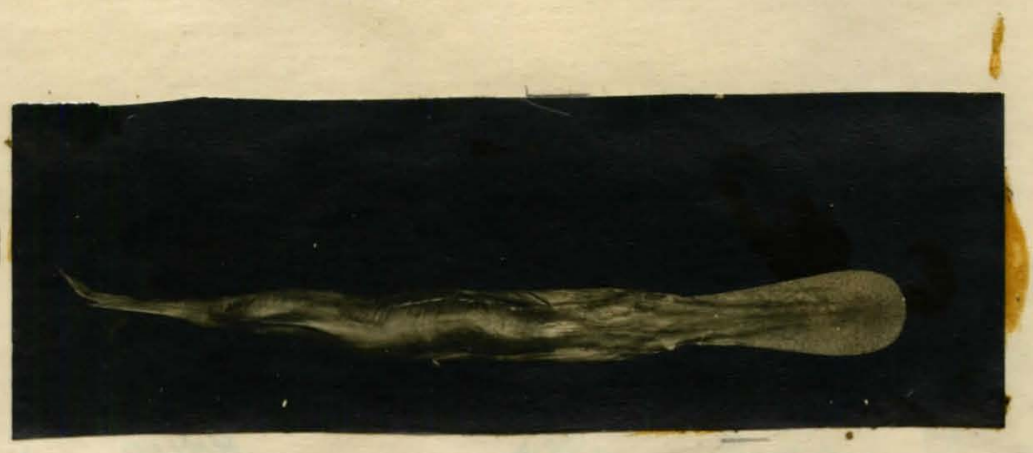

Iigure 2. Dorsal view of polyodon

spathula showing large padde-shaped

snout

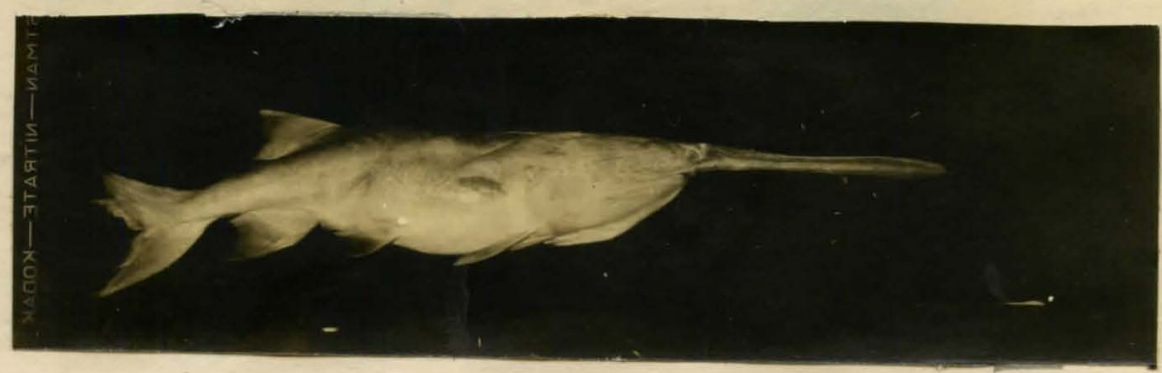

Bigure 2. Laterad view showing color variation from dorsal surface of body 


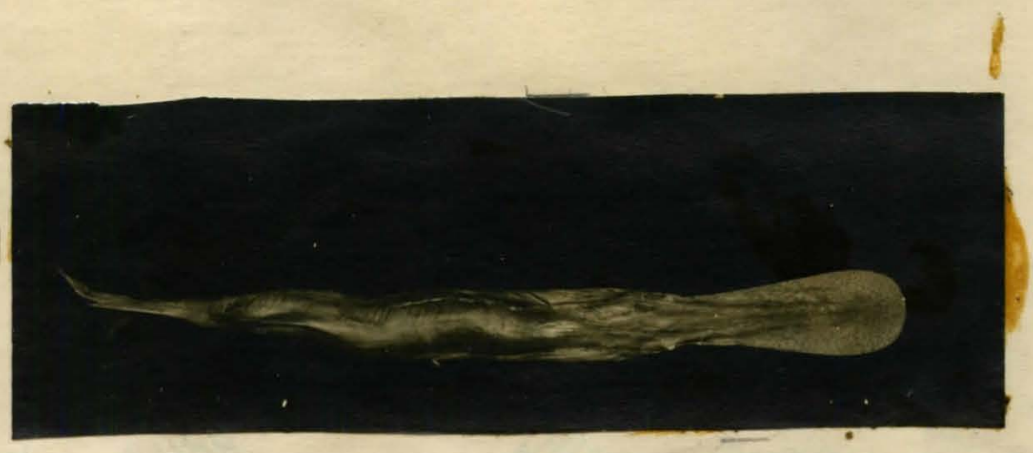

Figure 2. Dorgal view of pelyodon

spathula showing large padde-shaped

snout

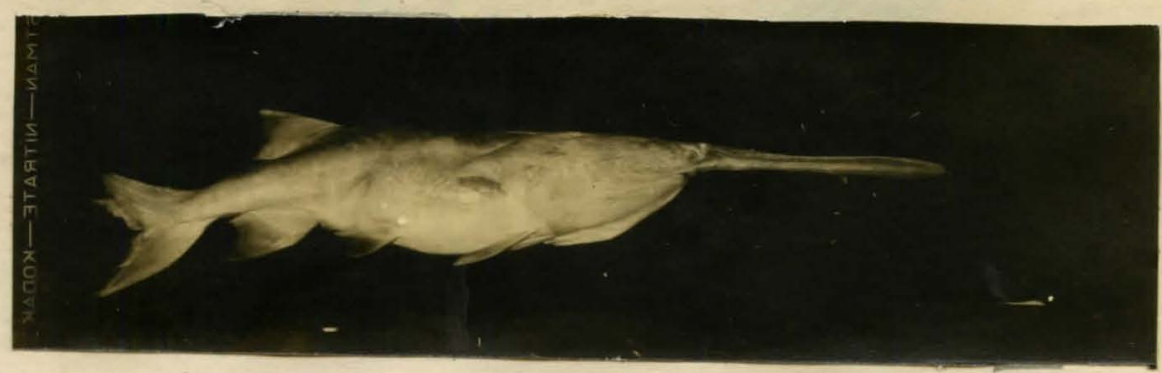

Pigure 2. Laterad view showing color variation from dorab surface of body 


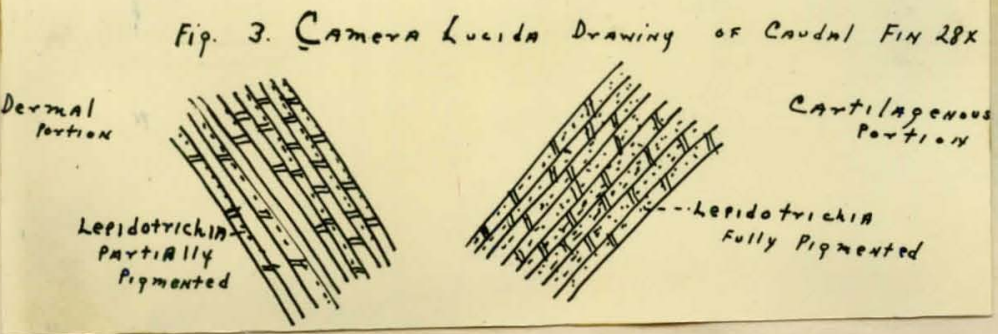

BIgure 3.

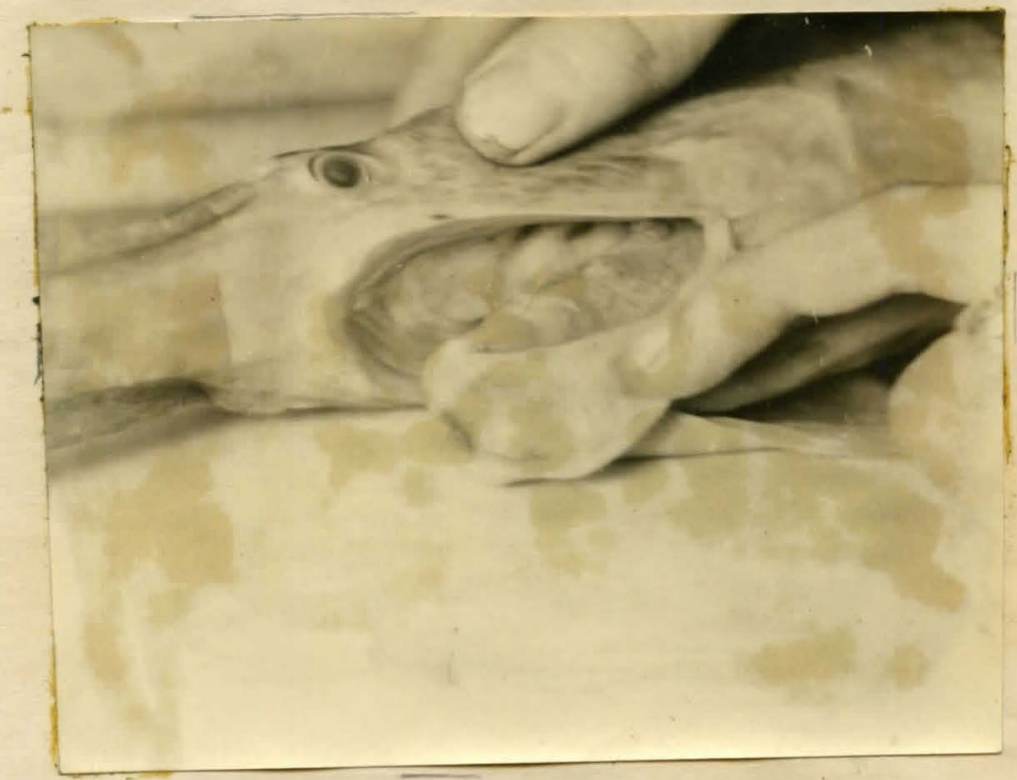

Bigure 4. Note large, ventral, horseshoe shaped mouth 


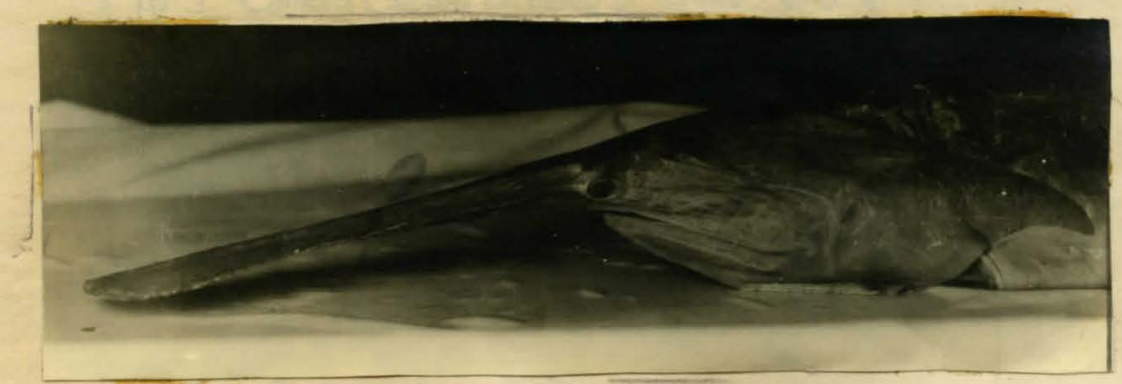

rigure 5. Shows eluster-like patohes containing sensosy pits on the opercusum

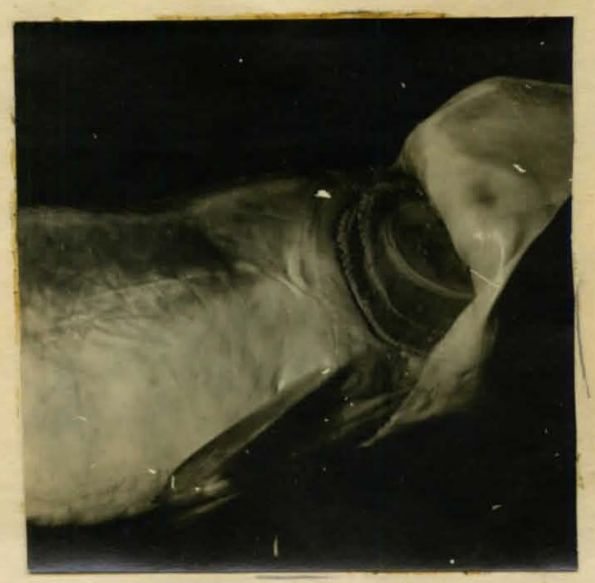

Figure 6. Hote fleshy operculum and gida structures beneath 


\section{Fig 7 Camera Lucida Drawing of Snout 28 X}

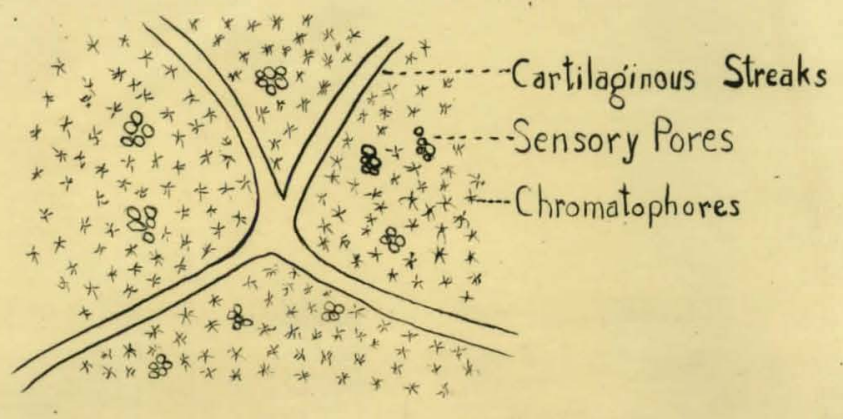

The sensory pores are found in grape-like clusters scattered lhroughout the bill between which are found the chromatophores.

5igare 7.

Fip. 8 Distribution of Chromatophores On Varlous Surfaces ore the Spaublll. C.L.D.28K

Ba $l 1 y$

Region

00

○

a.

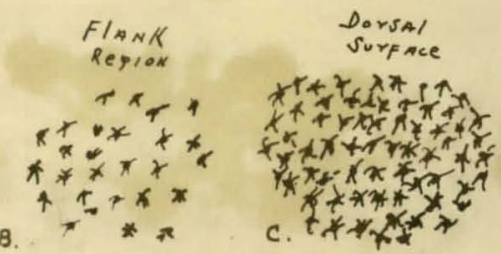

Q. Absence of Chromatophoves (Few yellow Pignent spots)

B. Moderate Number of Chromntophores.

c. Numerous Chromatophores 


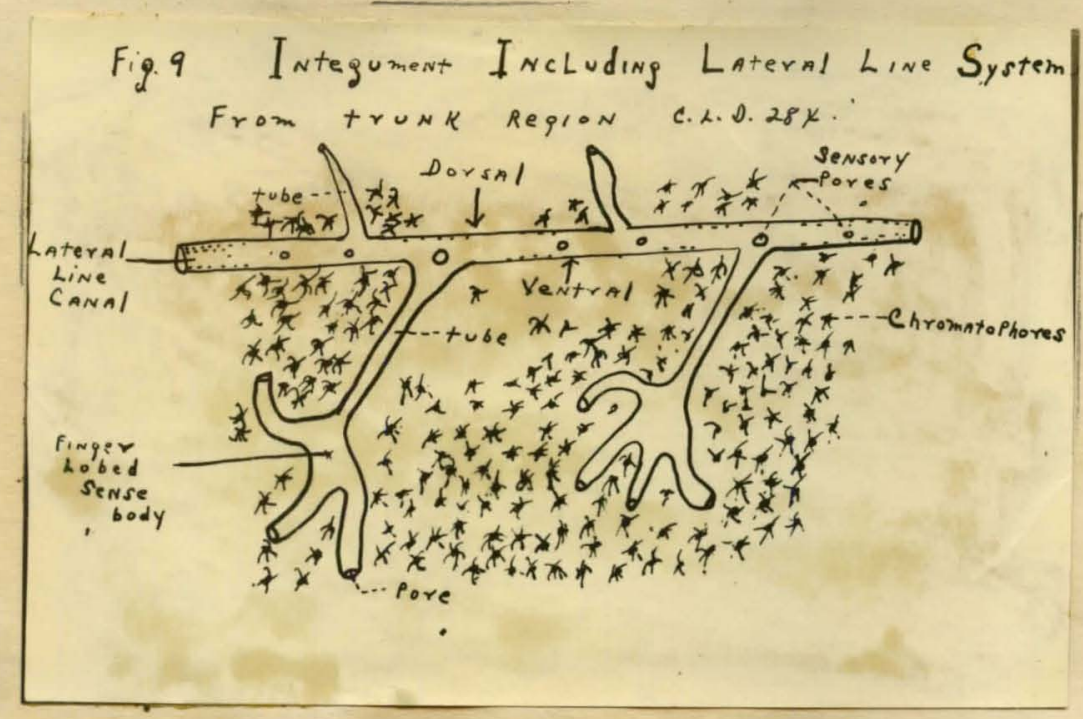

PIgure 9. Note that sensory pores lead directiy into lateral line canal
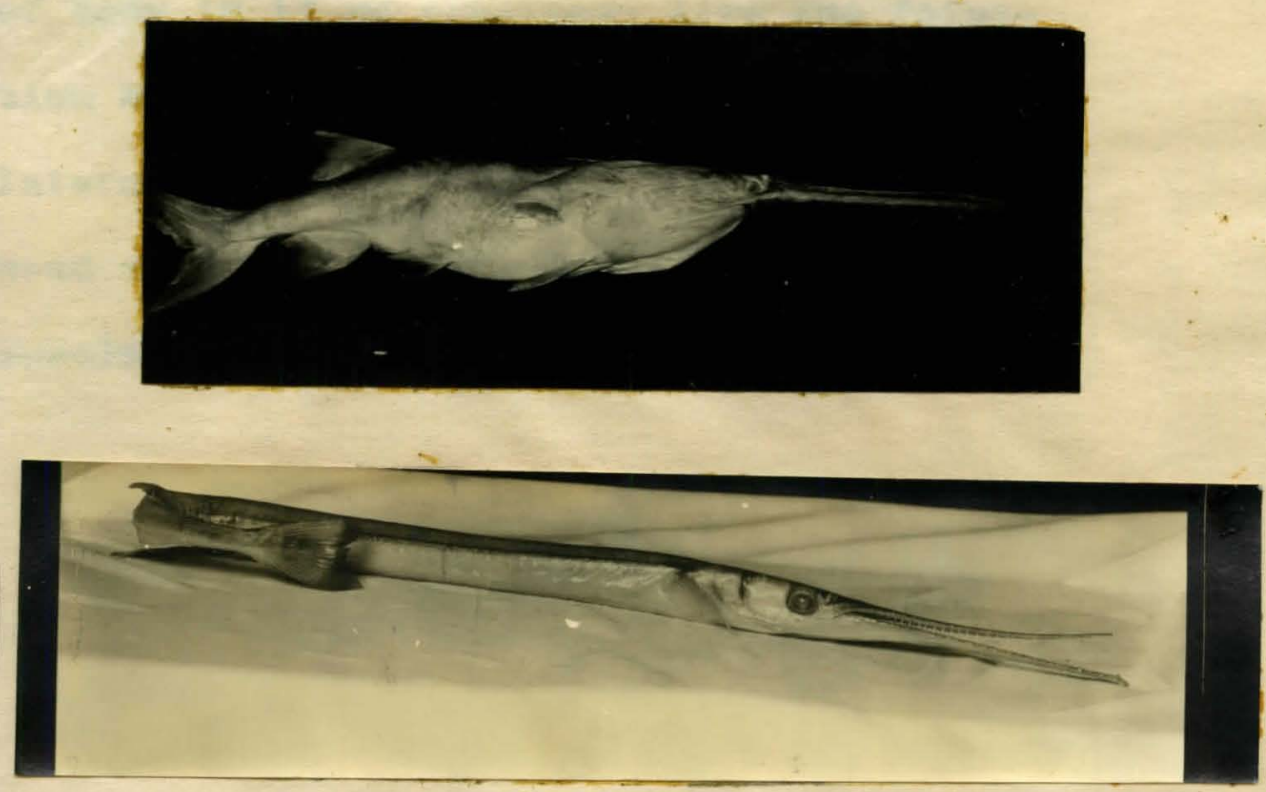

Figure 10. Note the many different externad features of two ganoids, the spoonbi13 and the needleflsh 


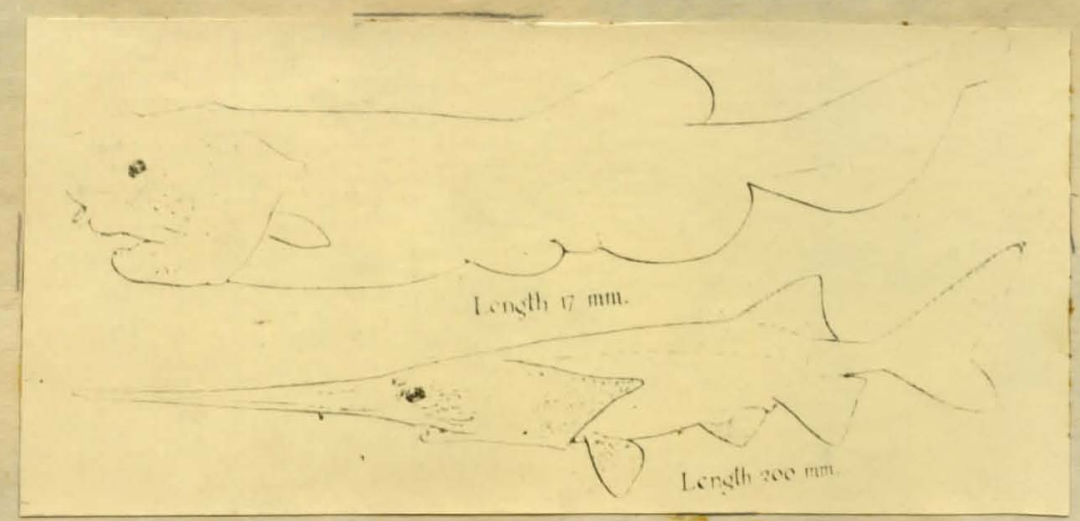

51gure 11. Rostlarva end young of polyodon apathula from Thompson (1933).

Wote large head, absence of complete Iin formation and proportion of depth to length of body in 27 mopecimen; al ao the formation of the snout, cosplete fin formation, Jateral Ine eans. and elongation of the head and body in general in tha 200 mas specimen. 


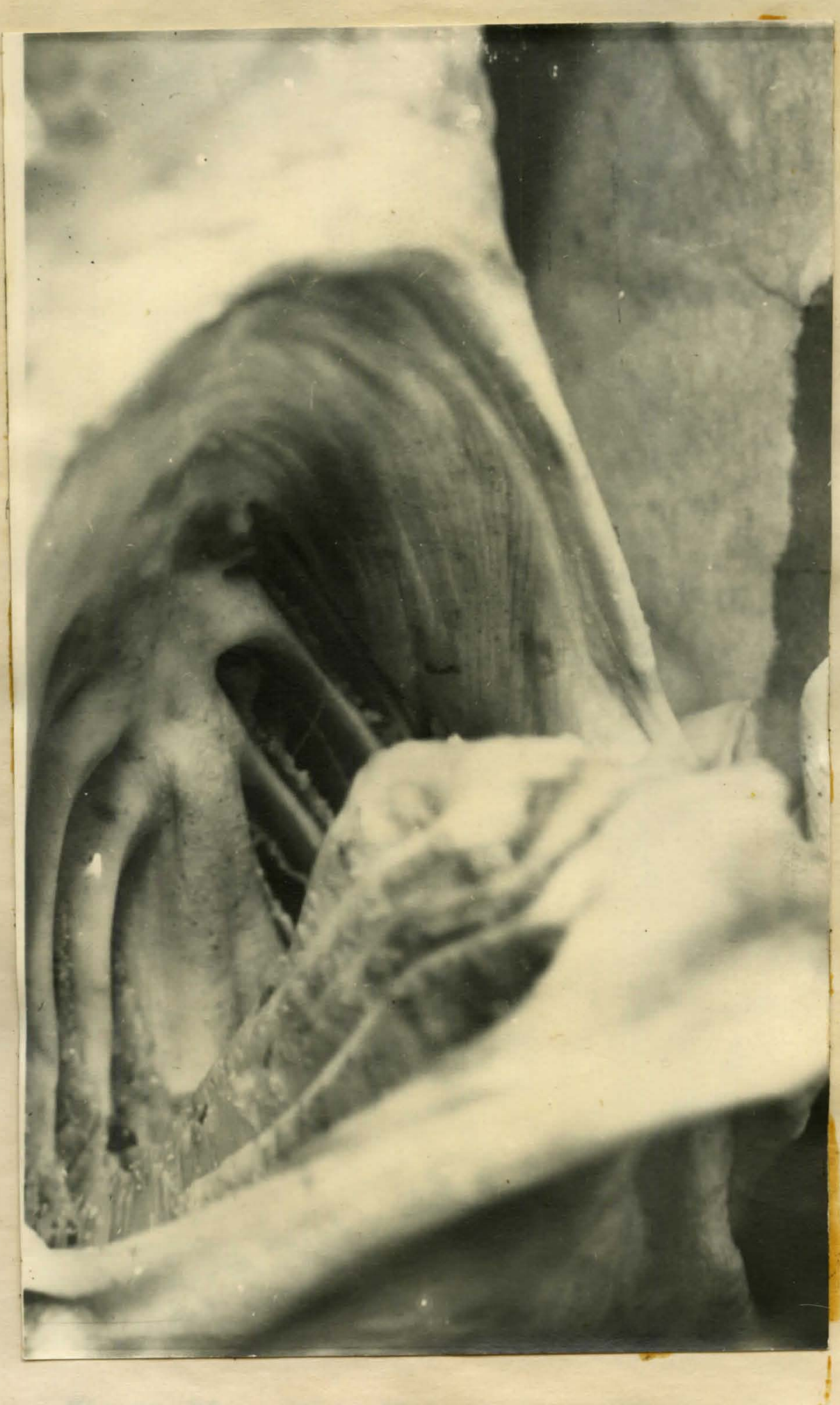

Pigure 12. Large fleshy mouth and absenoe of teeth 


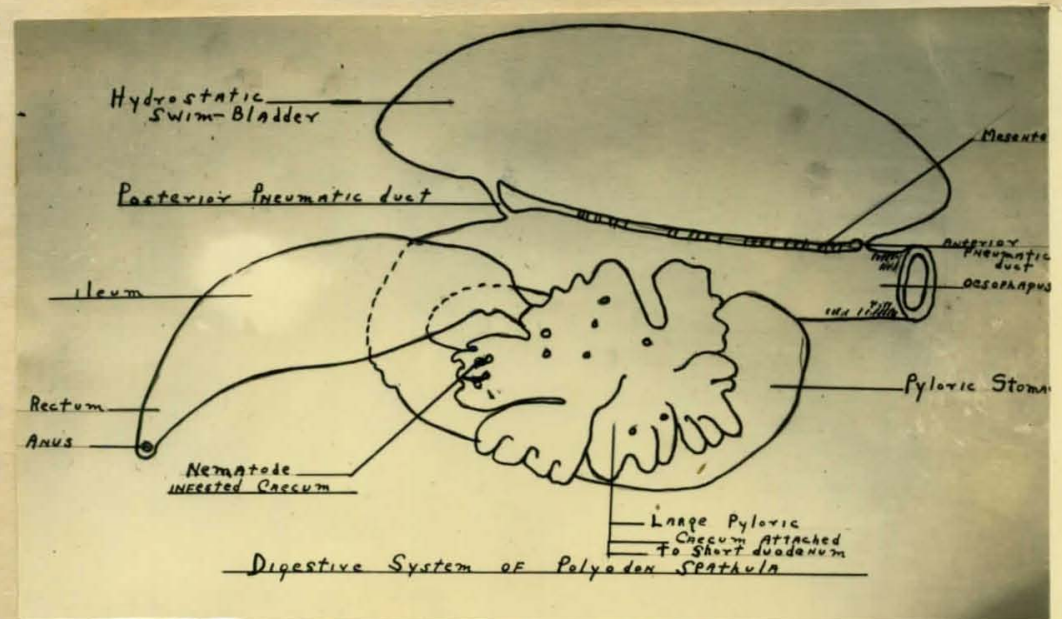

Bigure 13. Digestive system of Ralyodon @pathula. Note large pylorie caecum confluent at the base

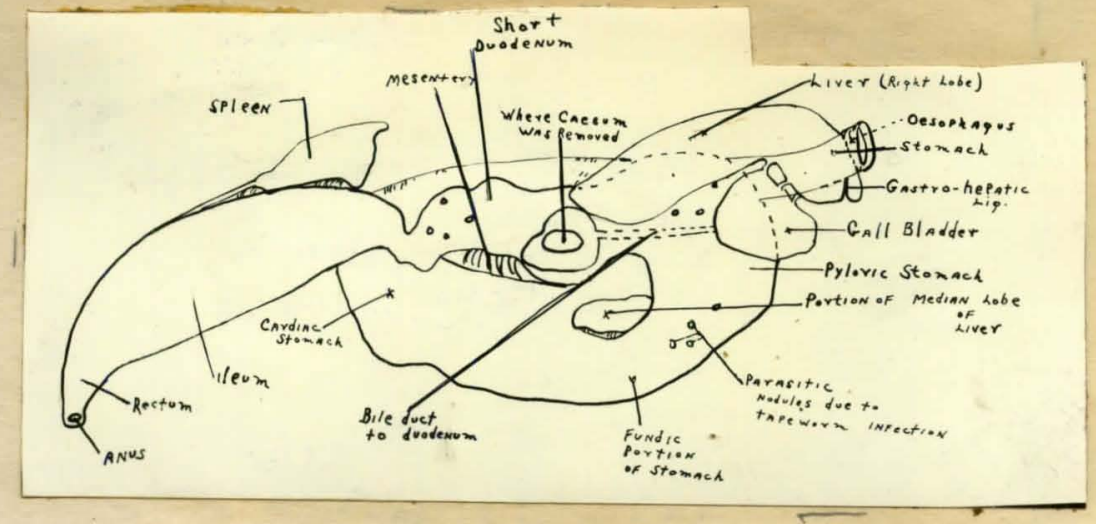

Pigure 14. Digestive system with oaecum removed 


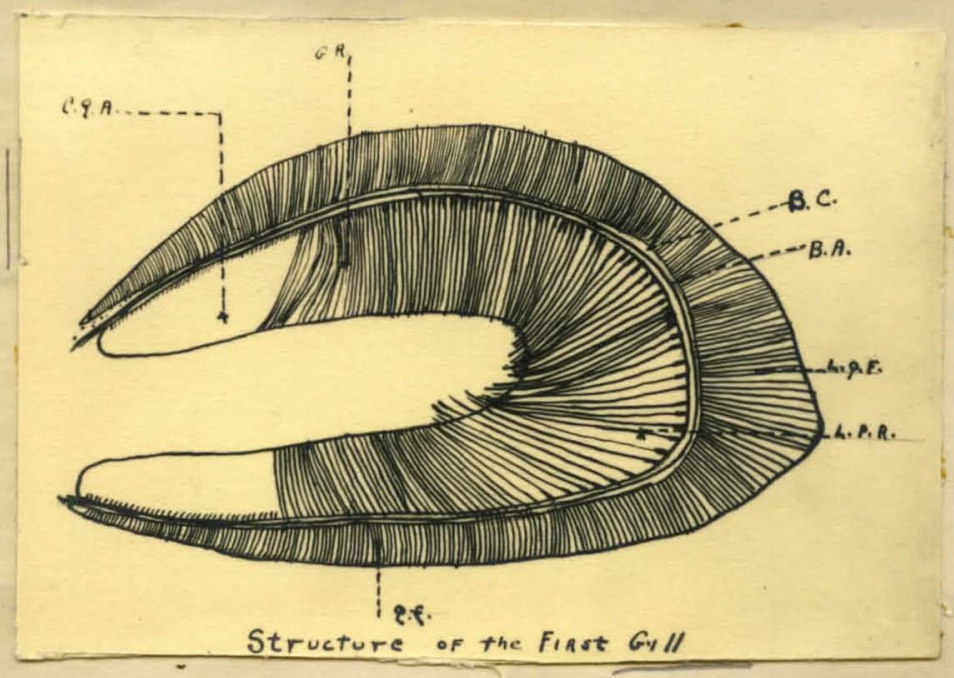

Bigure 15. Note tremendous number of gidj rakers and rilaments

C.․A. Cartilaginous gill arch B.A. Branchíal artery G. H. Q131 rakers $\bar{B} \cdot \bar{c}$. Branchisl canal

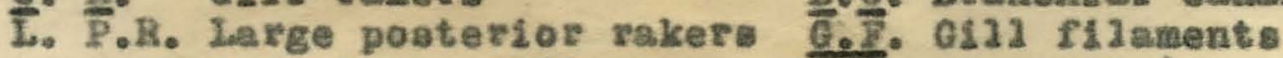
L.G.Z. Large 8111 f13aments (posteriorly)

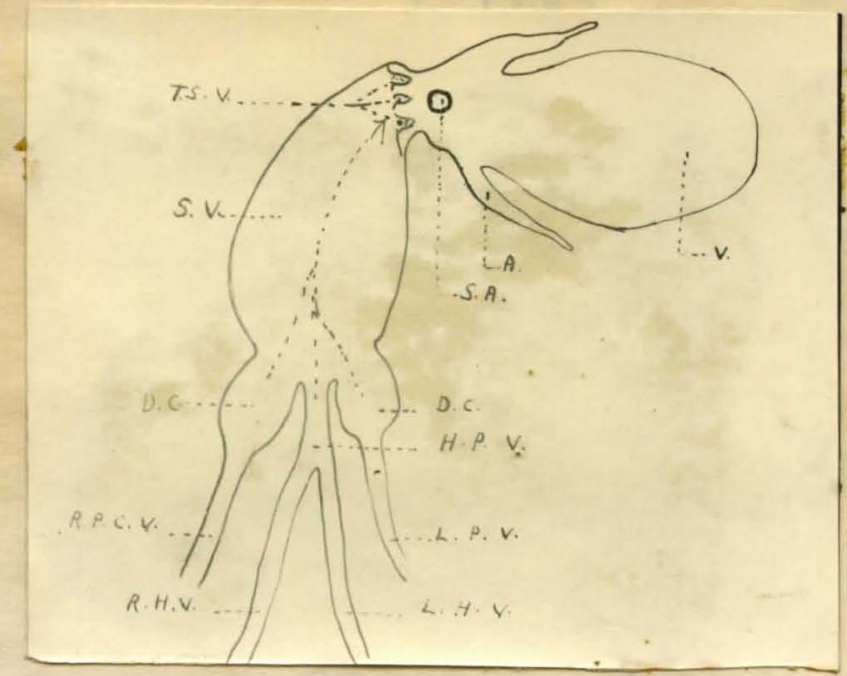

Higure 16. Relationohip of sinus venosus to heart. S.V. dorgal to heart in normal position 3.S.V. Three sino-auricular valve $S_{0} V_{0}$ sinue venosus R.P.C.V.Right post-cardinal vein D.C. Duet of Cuviar R.H.V. Right hepatic vein L.H.V. Left hepatio vein L.P.V. Left post-cardinal vein HoP.V. Hepatie vein (Jarge) S.Â. Sino aurioular aperture A. Auriele V. Ventriele 


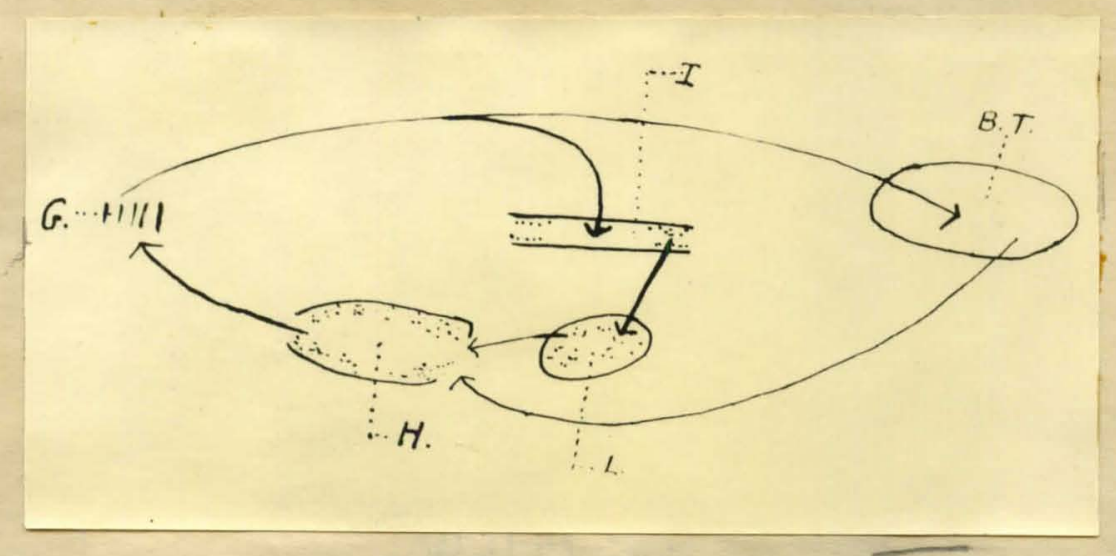

Yigure 1\%. plan of circulation in e fieh

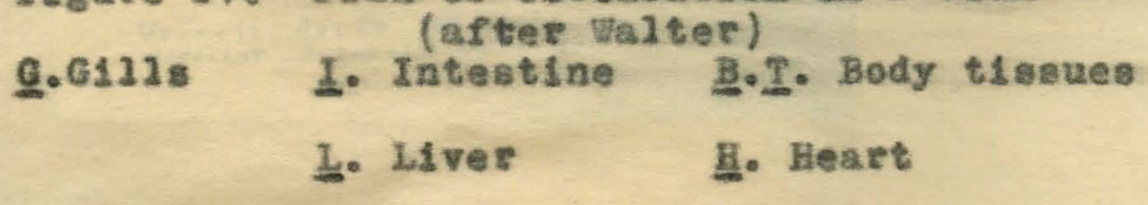

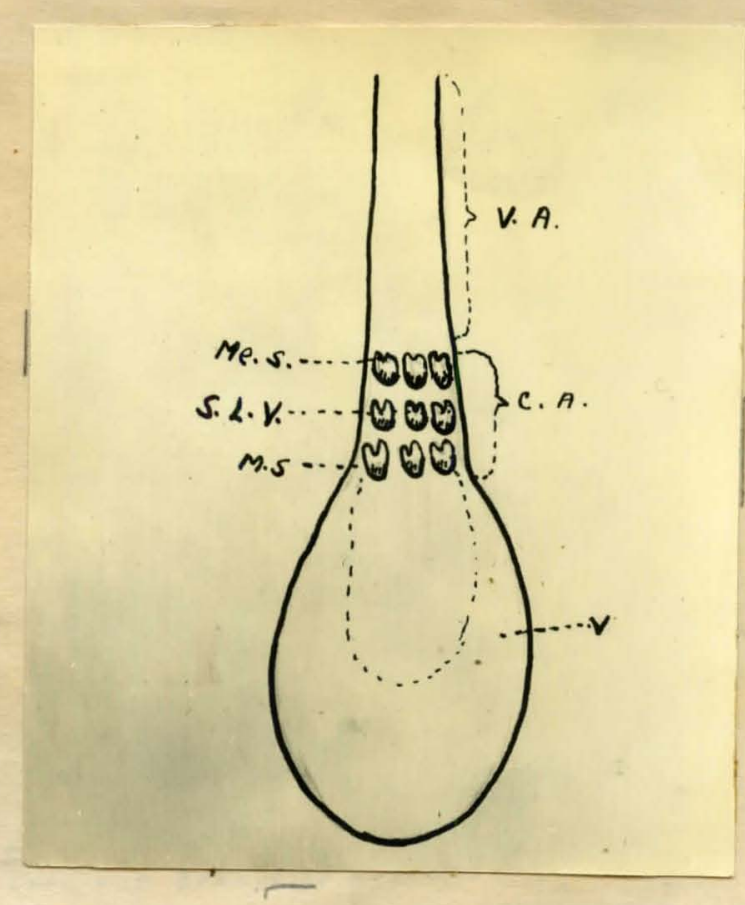

Bigure 18. Conus exposed to show arrangenent of semi-1una valves

‥A. Ventral aorta C.A. Conus arteriosus S․․․․ Send-lunar valve

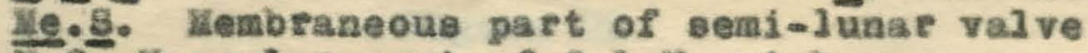
M.S. Husculae part of S.L.V. at bsae 


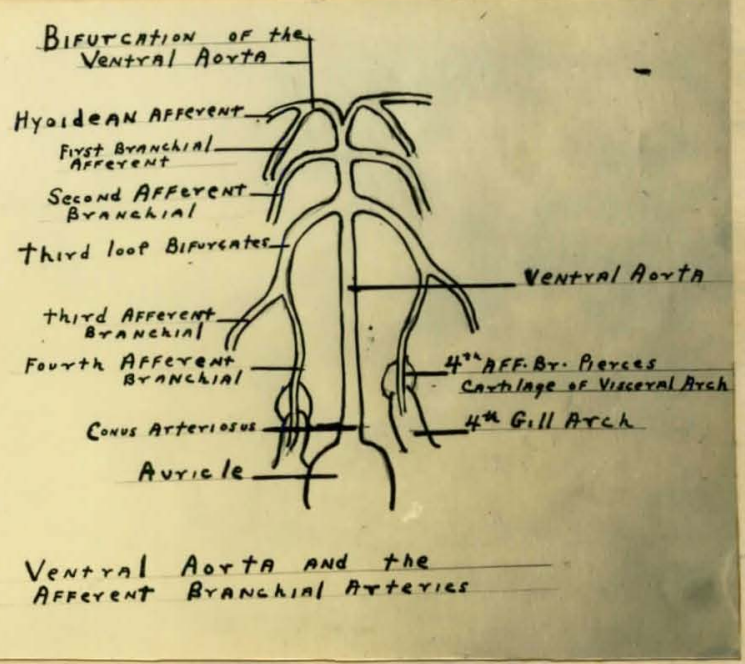

\section{Iigure 19.}

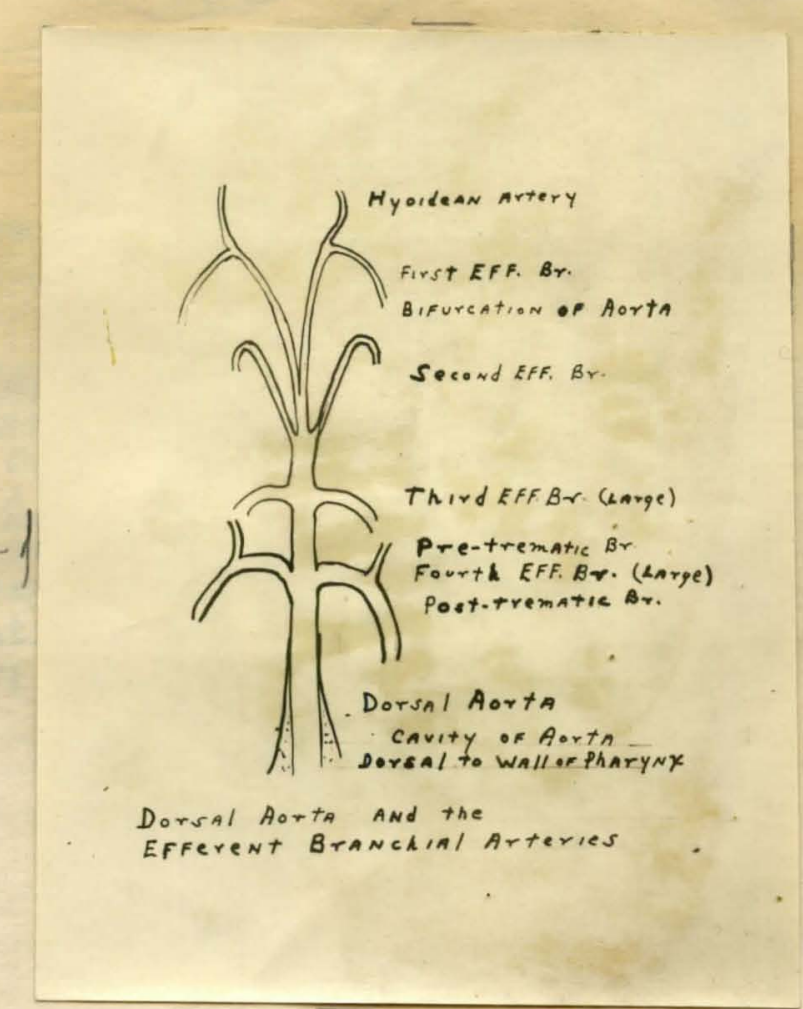




\section{Pigure 21}

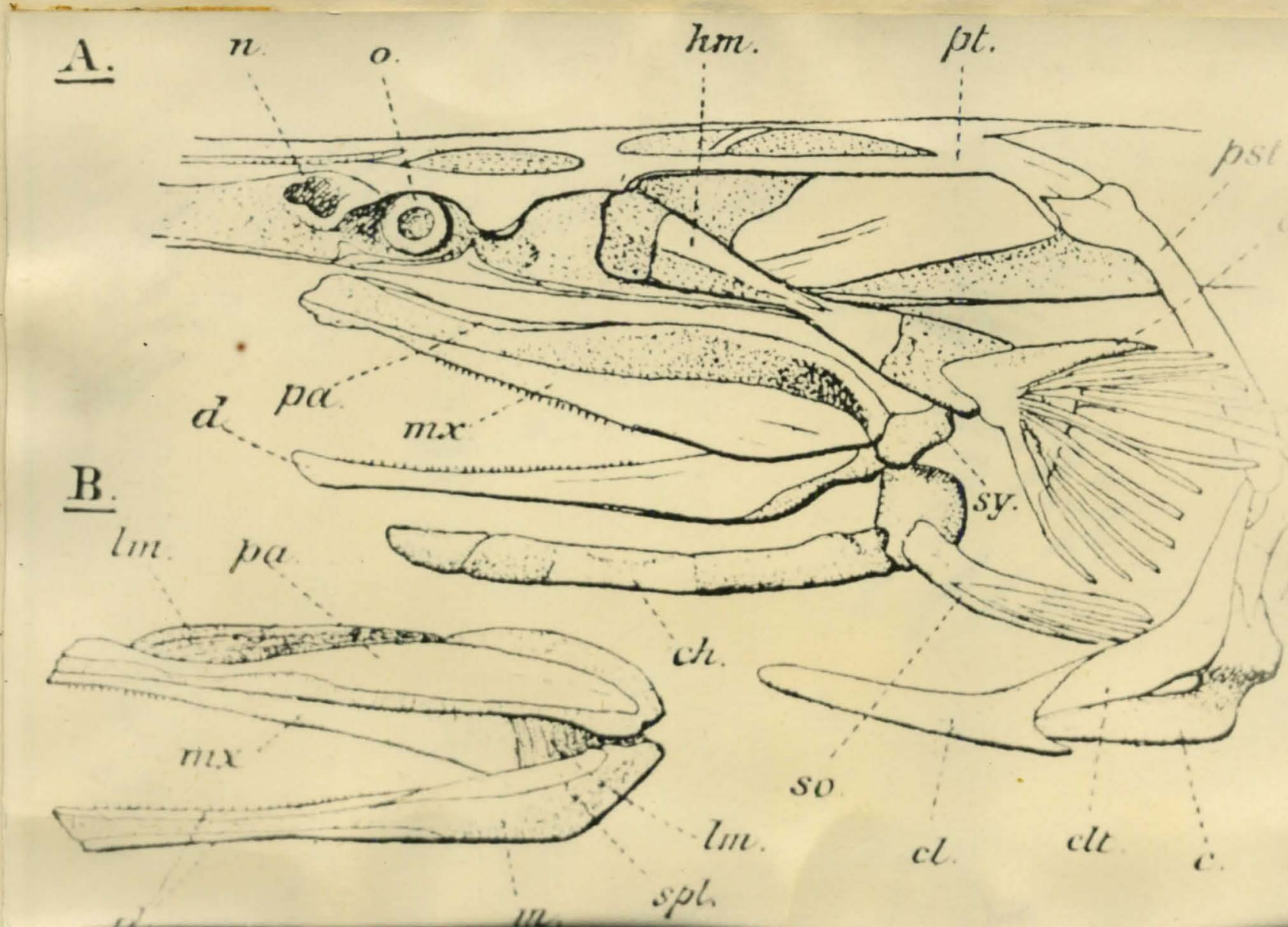

Polyodon folium. Lac. (After Traquair.) A. Left-side view of skull, jaws, and pectoral girdie; E. inmer view of right jaws. E. Corscoid: ch, ceratohyal; 도. claviele; clt. oleithrum; do dentary; he, postelaviole; hm, hyomandibular; lm, levator muscle; m, Keckel's cartilage; mx, max13la; n. olfactory capsule; ㅇ. optio capsule; on opercular; pa. palatine; pst, post-temporal; pt. pterotic; so. subopercular; apj. oplenial; sy. symplectic.

(Brom Goodrioh, Vert.

Cranjata, igo9) 


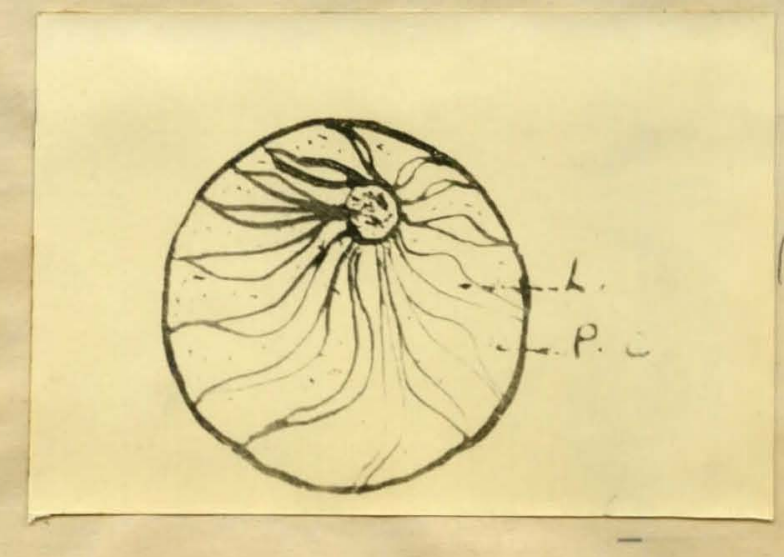

19gure 22. Arrangement of lamellae in nasal Possa. 1. Lamellae has olfsetory senge cells E. . . Pigaented sensory eells

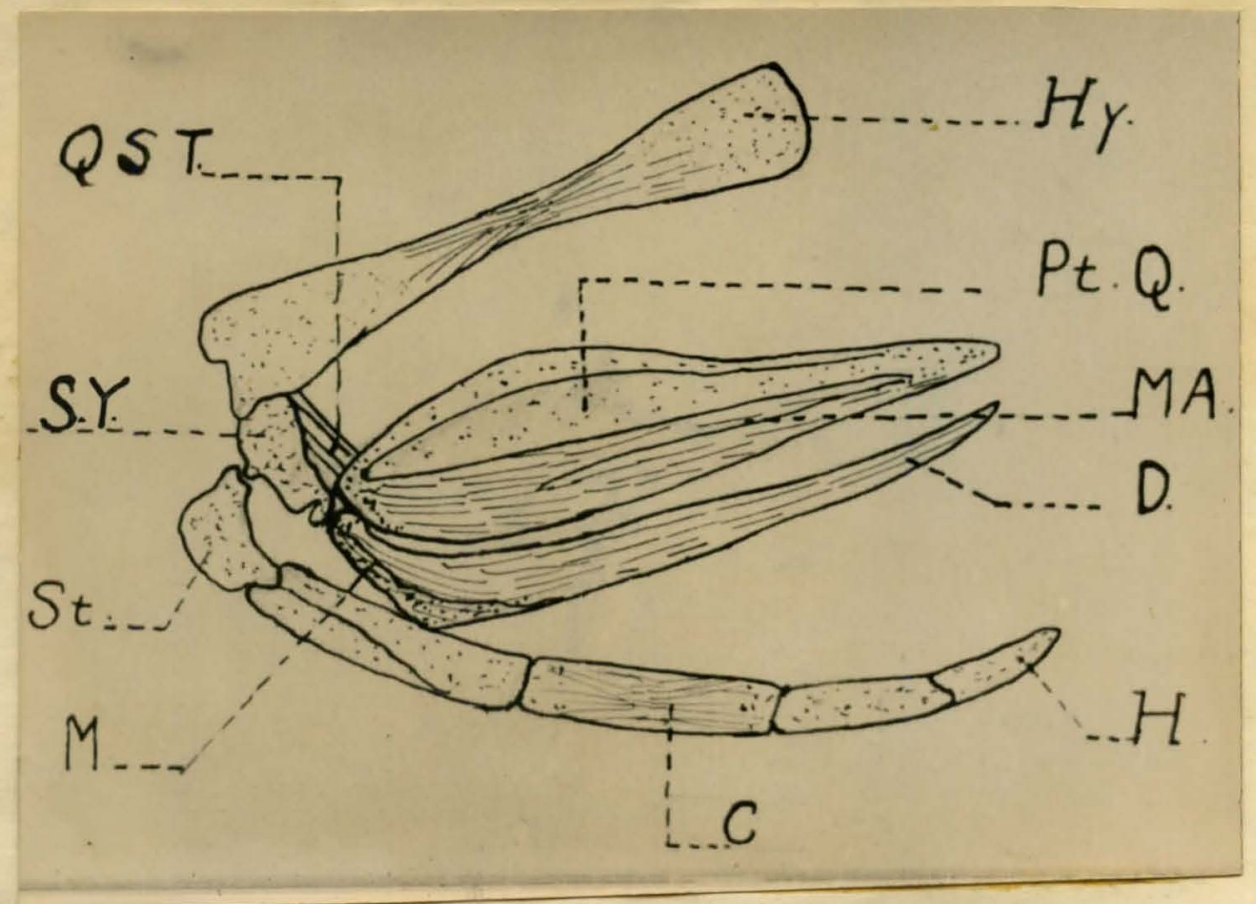

71gure 23. Part of skul1 showing relationship and atschments to the symplectio cartilage. Nat. size of small apecimen ( $60 \mathrm{cas}$ )

c. es ratohyal D. dentary H. hypohyal

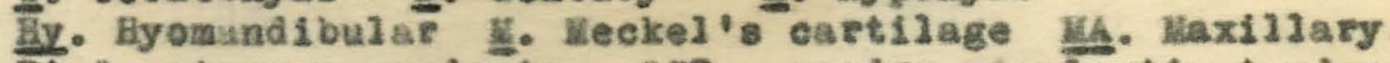
Pt. 3. pterygo-quadrate QST. quadro-sympleotic tendons St. stylohyal Sy. symplectre 
Iigure 24. Dorbal view of the skujl of Polyodon gpathula

C. chondroersaniam

E. Sontonelle

Fै. รosea

is. fronts]

H. hyomand 1bular

OC. olfactory eapsule

of. optic fose

P. parietal

Pt. pterot1o

홍 snout

O. ossiole

‥ . rostrum 


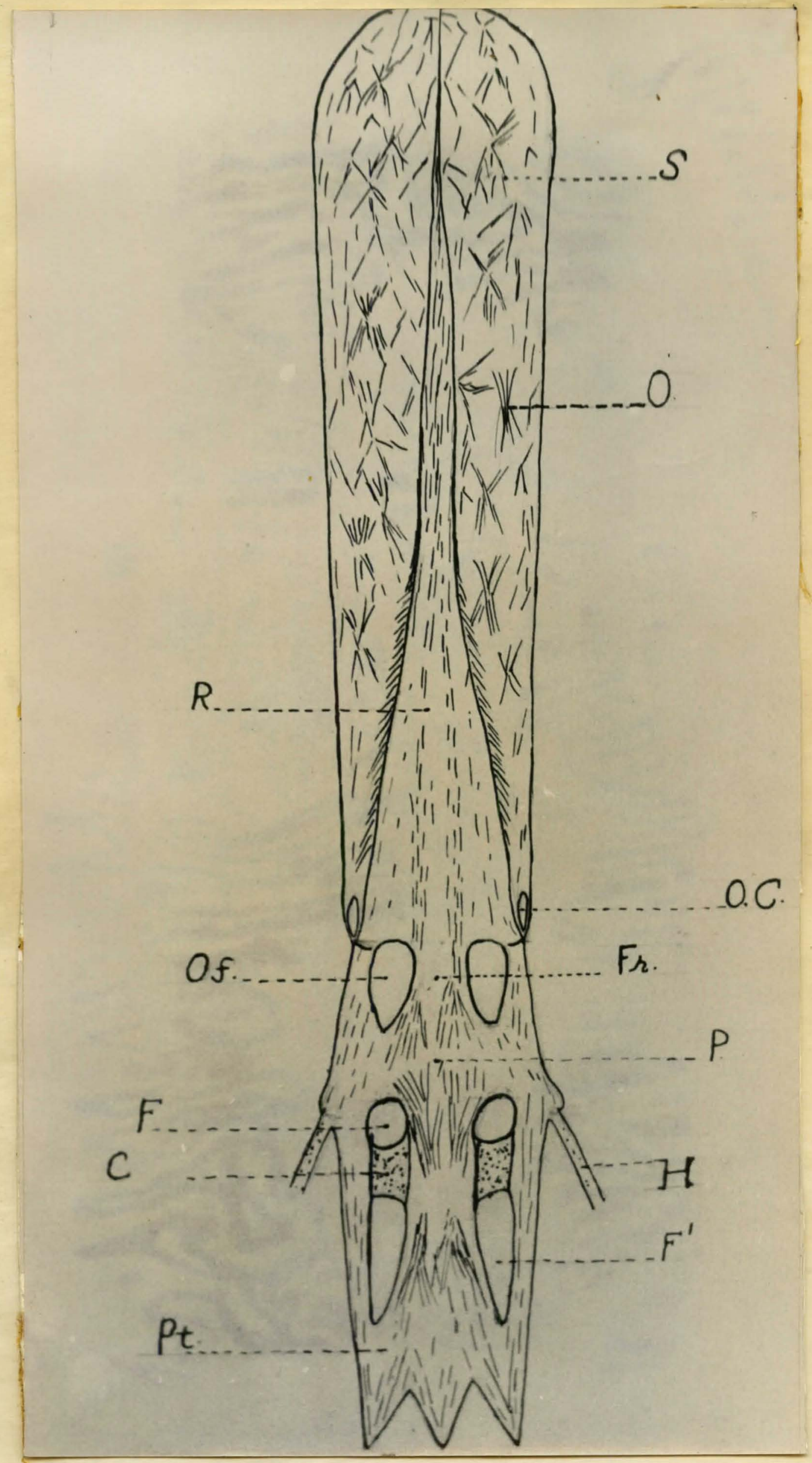




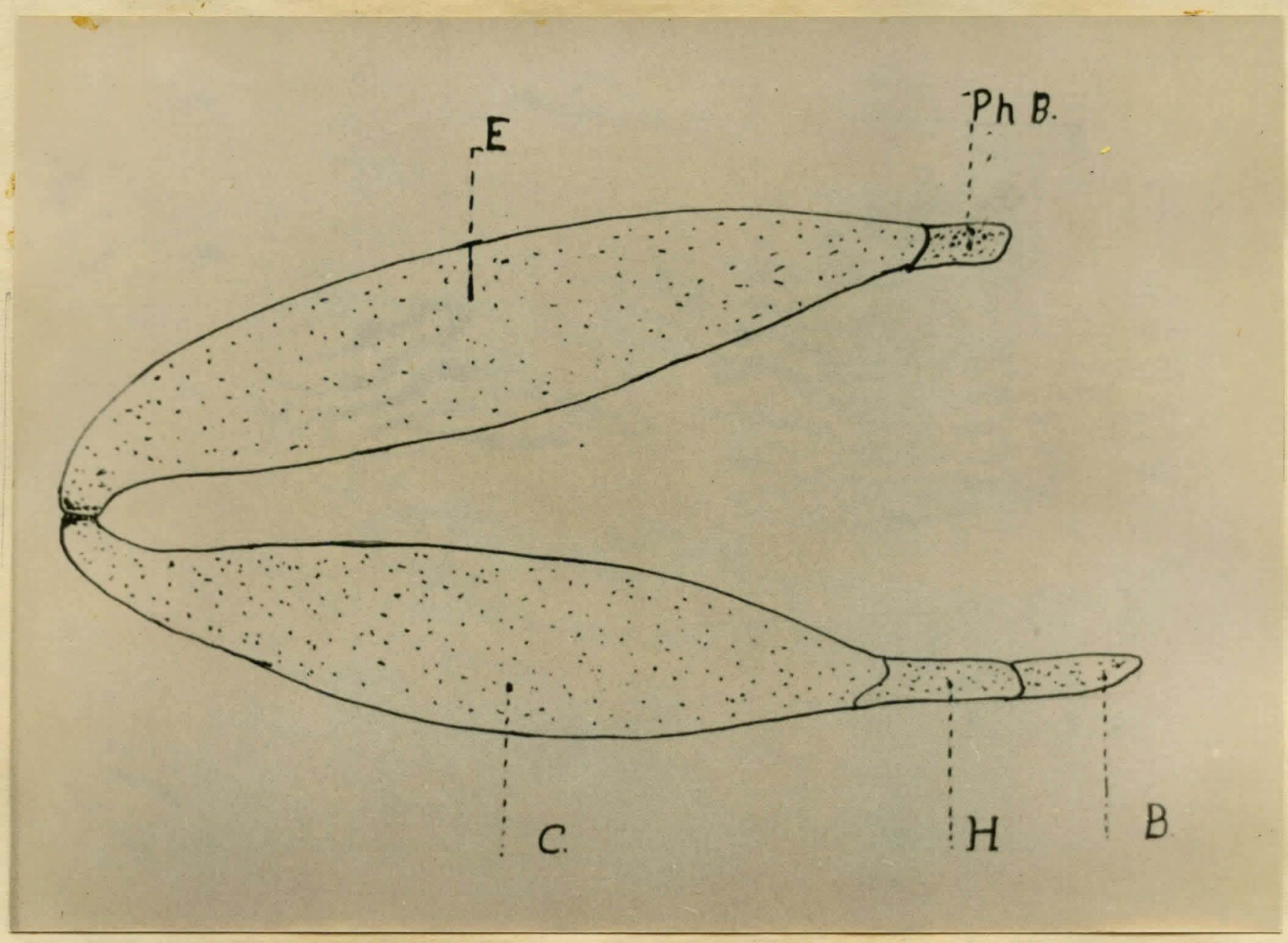

\$1gure 25. A typieal branchial aroh of $90 \mathrm{~cm}$. apecimen (nst. as ze)

3. Spibranchial

Phi], Pharyngo-branchial

C. Ceratobranchial

프. hy pobranchial

E. Baaibranchiad 


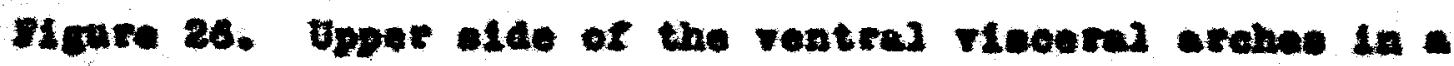
typleal 90 en. epecinen

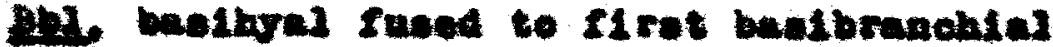 \\ 11. myolural jolns besthed \\ I. Rirat wpobranchiad \\ C. enectehya \\ Fil. eetetebrenchial \\ IR. Tued hypobranohial ith
}




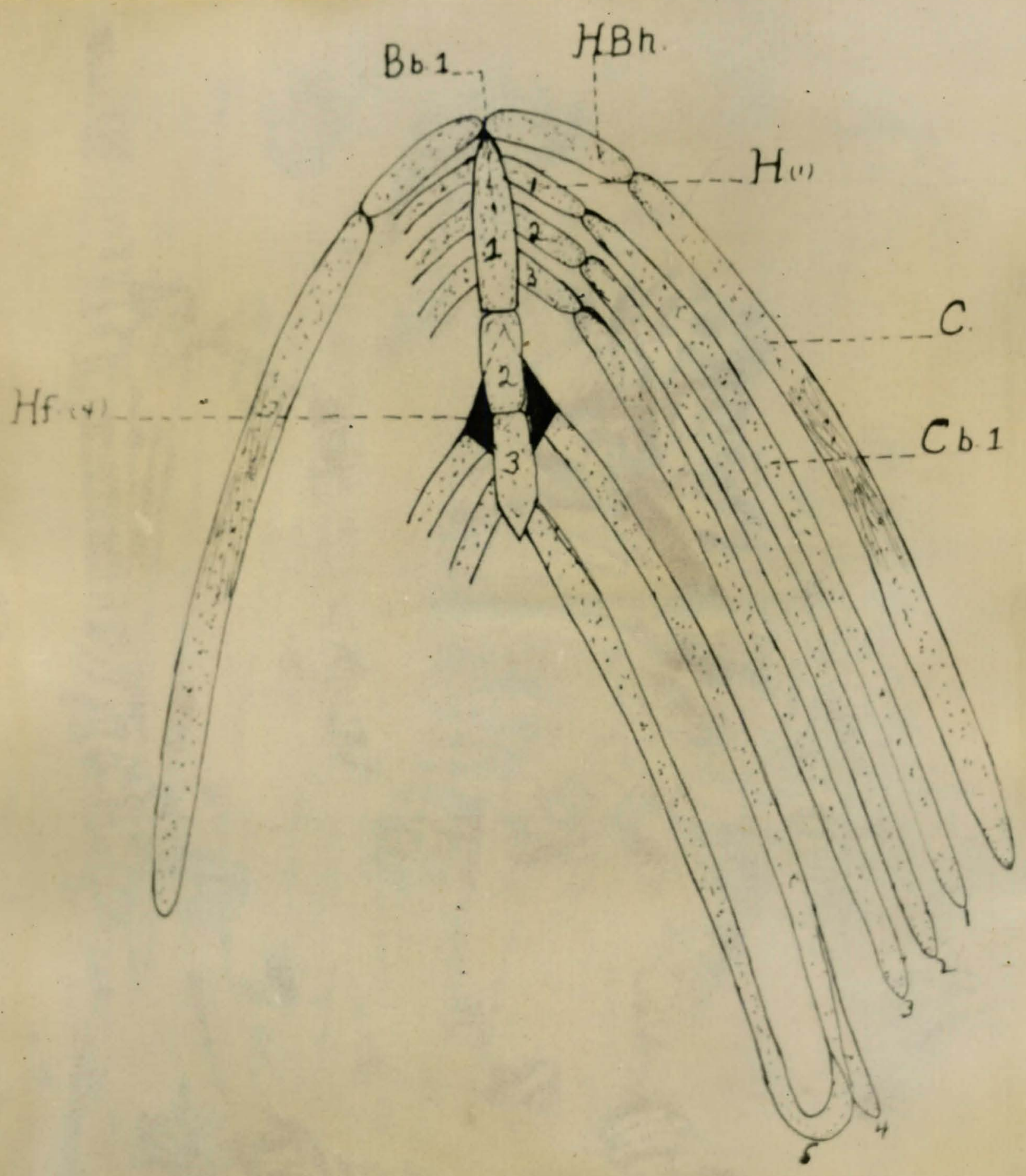




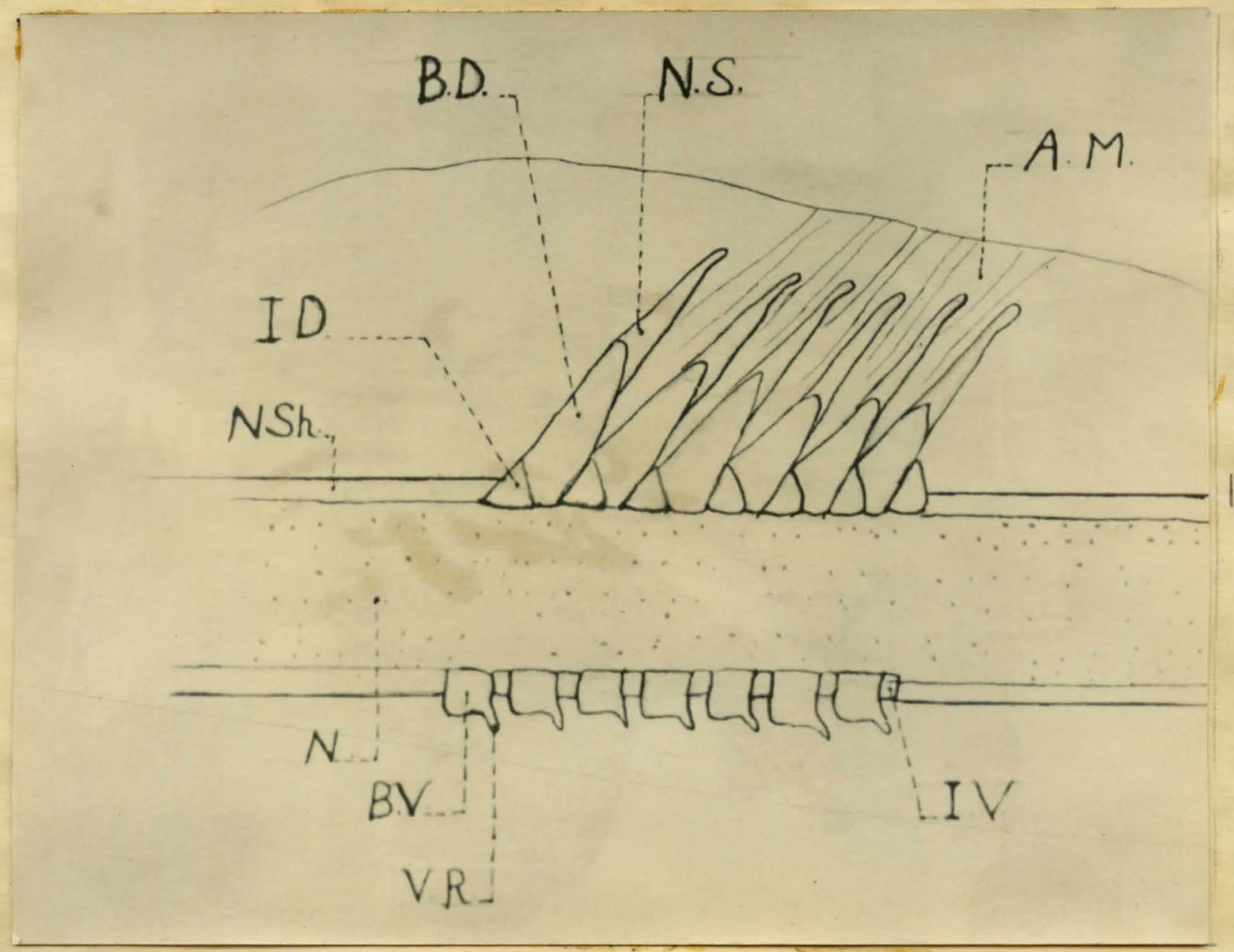

1igure 27. Latersi vies of vertebral column from midtrunk region (2X)

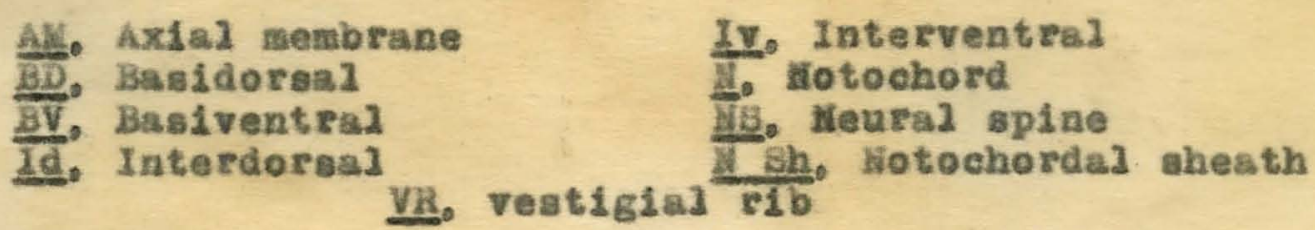




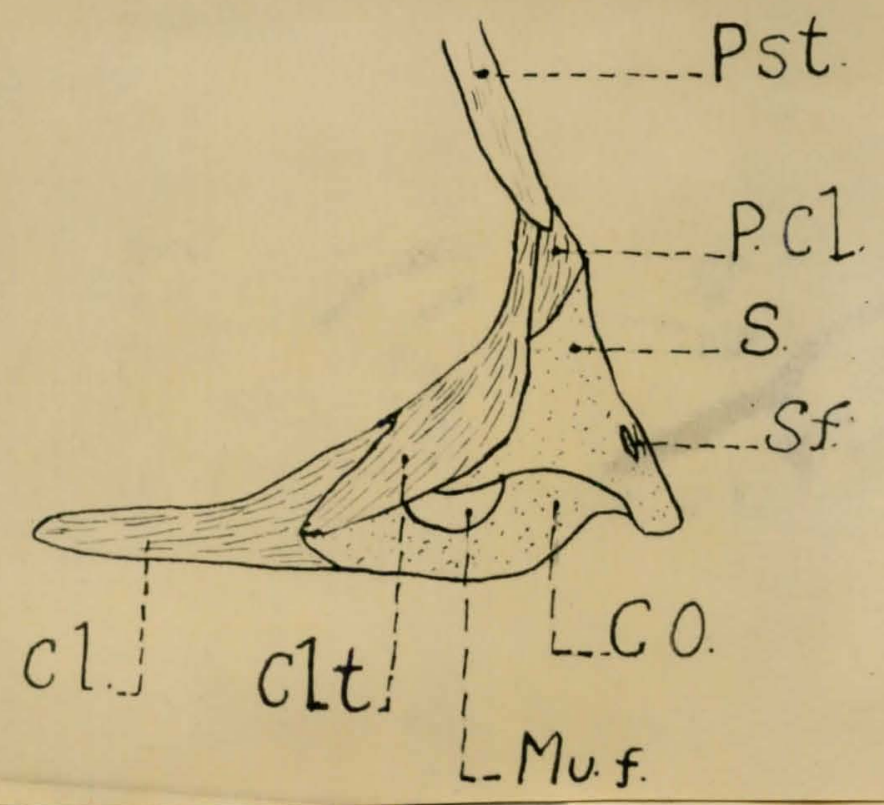

Piguce 28. Fectoral girdle of a $60 \mathrm{~cm}$. opecimen nat. aize. Cl. elaviele Clt. eleithruv co. coracoid Iuf. macular foramen RCl. post-cIavicle Fet. post-temporal S. Scapula Sf. scapula foramen

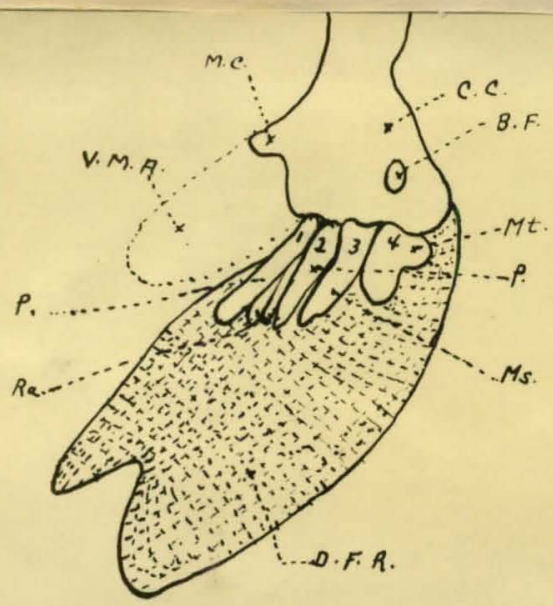

Median View of Pectoral Girdle and Fin.

Higure 29. Hedian view of pectoral girdje and fin

L. E. median cartilage p. propterygín

D.P. R. dermad fin raye W.I. metopterygium
V. ㄱ. …- radiels (2) …… mesopterygium B..$\overline{\text {. }}$ branchial foramen 